Historic, Archive Document

Do not assume content reflects current scientific knowledge, policies, or practices. 

ANNUAL CATALOGUEUT'

C H U.R EH'S

SEED STORE

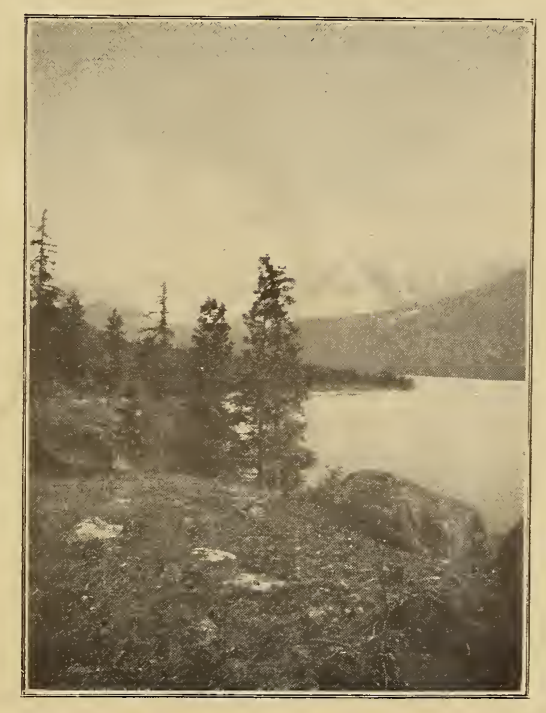

1909

915 FIRST AVENUE SPOKANE, WASH. 


\section{CHURCH'S SEED STORE SEED ANNUAL-1909}

\section{TO OUR PATRONS AND FRIENDS:}

We have been selling and producing Seeds, Poultry Supplies and everything for the Farmer, Gardener and Poultry Man for the past ten years, and the growth and development of our business is one of the best inducements we can offer to try our goods.

CHURCH'S SEED STORE was the first seed store to start in Spokane. We well remember in our first year how hard it was to induce some gardeners to try our seeds. They had their particular dealers in the east with whom they had always traded, and this was hard to overeome.

However, as the years passed by, our rapid increase in business has proven to us that Eastern competition is not what it used to be. Western grown seeds, acclimated to our climate and soil, have proved themselves far superior.

\section{How to Order and Terms of Business}

OUR TERIMS ARE STRICTLY CASH WITH THE ORDER. We do not send C. O. Dd, as the cost of collecting return charges is quite an unnecessary item of expense and, the prices being given, we can conceive of no necessity to warrant goods being so sent.

HOW TO SEND MONEY. Remittances may be made at our risk by any of the following methods, viz.: Postal IMoney Order, Draft on New York or Chicago, or Express Company's Money Order.

The rates charged for Postal Money Orders and Express Money Orders are now so low that these are the best ways to remit.

FREE OF POSTAGE OR EXPRESS CHARGES. Packets, Ounces, Two Ounces, Quarter Pounds or Pounds, ordered at list prices, will be sent free by mail or express.

Customers ordering enough for a freight shipemnt, 100 pounds or more, or desiring to pay their own express charges, may deduct 10 cents per pound from prices of this catalogue on all seeds quoted by the pound or less.

PREPAID STATIONS. Many small railroad stations are prepaid stations, and the railroads will not accept freight for such points unless charges are fully prepaid. It will save delay if you ascertain if your station is a prepaid one before sending your order and include enough money to cover freight charges if it is.

IF SHIPMENTS DO NOT ARRIVE promptly after being notified by us, please advise, and we will have them traced at once.
MISTAKES. In executing thousands of orders it is impossible to avoid some errors, and we want our patrons to notify us promptly if any error occurs that we may rectify with the least possible delay.

NAME AND ADDRESS SHOULD ALWAYS BE GIVEN. We frequently receive letters containing nıney orders, which we cannot fill because the sender has failed to sign his name or the $\mathbf{P}$. O. address is omitted and the post mark being blurred, we are unable to fill the order, no matter how much we desire to do so. Use our Order Sheet whenever you can, filling out the blank and signing your name, and you will have no cause to censure us.

GUARANTEE. Complaints made that seeds are not good should quite as often be attributed to other causes as to the quality of the seeds. There are hundreds of contingencies continually arising to prevent the best seeds always giving satisfaction, such as sowing too deep, too shallow, in too wet or too dry soil; insects of all descriptions destroying the plants as soon as or before they appear; wet weather, cold weather, frosts, chemical changes in the seeds induced by temperature, etc. For the above reasons it is impracticable to guarantee seeds under all circumstances.

We give no warranty, express or implied, as to description, purity, productiveness, or any matter of any seeds we send out, and we will not be in any way responsible for the crop. If the purchaser does not accept the goods on these terms they are at once to be returned.

\section{CHURCH'S SEED STORE SPOKANE, WASH.}




\section{ORDER BLANK \\ FOR NORTHERN GROWN SEEDS FROM \\ CHURCH'S SEED STORE, SPOKANE, WASH.}

915 First Avenue

Gentlemen: Enclosed find $\$ \ldots \ldots \ldots \ldots \ldots$ for the following order:

Name

Express or freight office...

State

Postoffice

Date.

$.190 \ldots$

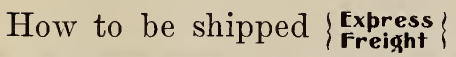

THINGS TO REMEMBER-Write your name and address plainly. Money may be sent by postoffice or express money order, bank draft or stamps, for amounts less than one dollar. We pay postage on all seeds except mangels, beans, peas, corn, grass seed, and miscellaneous fodder plants. When these are ordered, add 10 cents per pound for postage. Market gardeners and others who use seeds in large quantities are requested to send us a list of their postage. greatest care to have all seeds pure and reliable, we do not give any warranty, express or implied. If the purchaser greatest care to have all seeds pure and reliable, we do not give any warranty, express or implied. If the purchaser
does not accept the seeds on these terms and conditions, they must be returned at once, and the money that has been paid for same will be refunded.

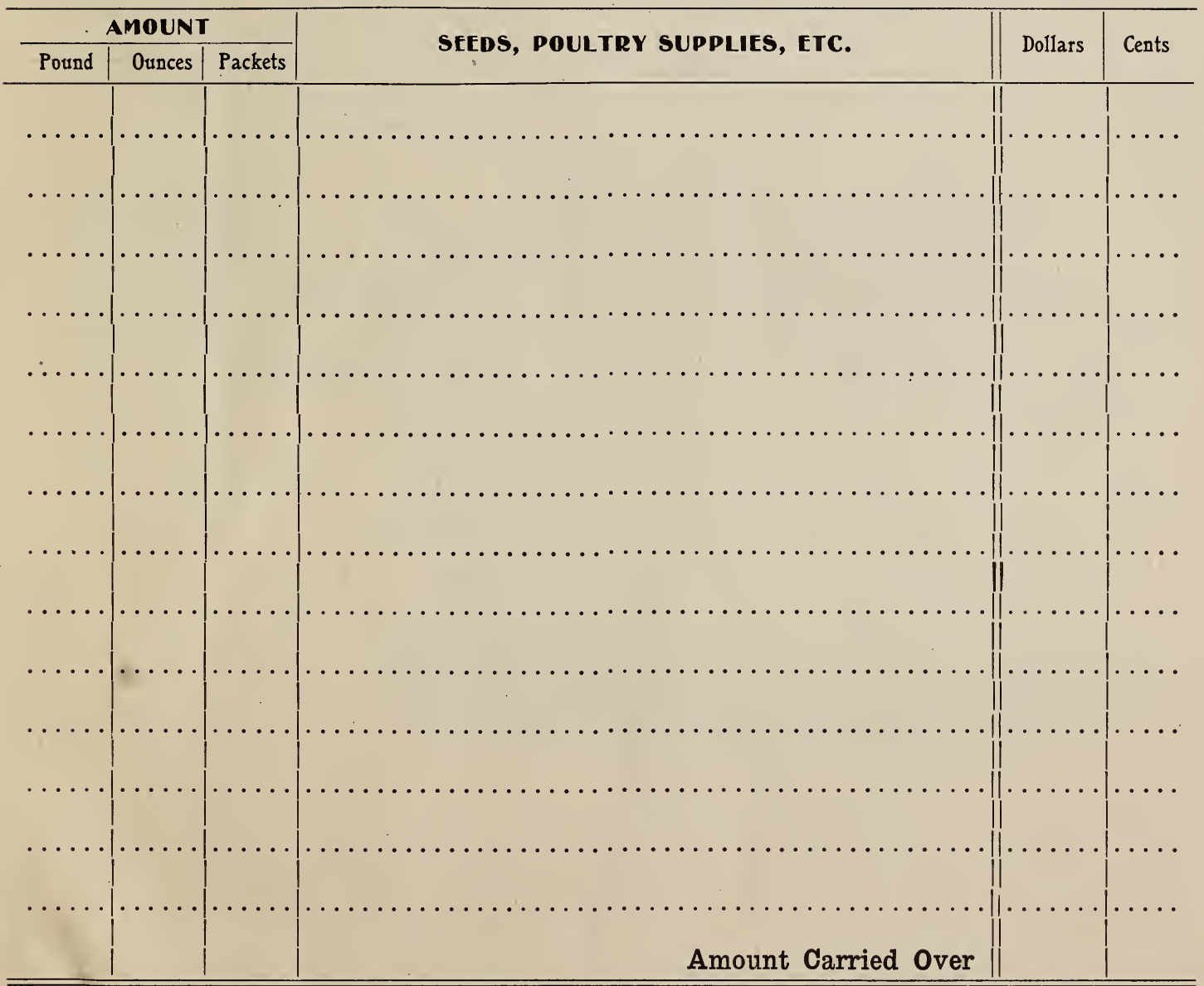

In making your order, please give the price, to avoid delay and error 


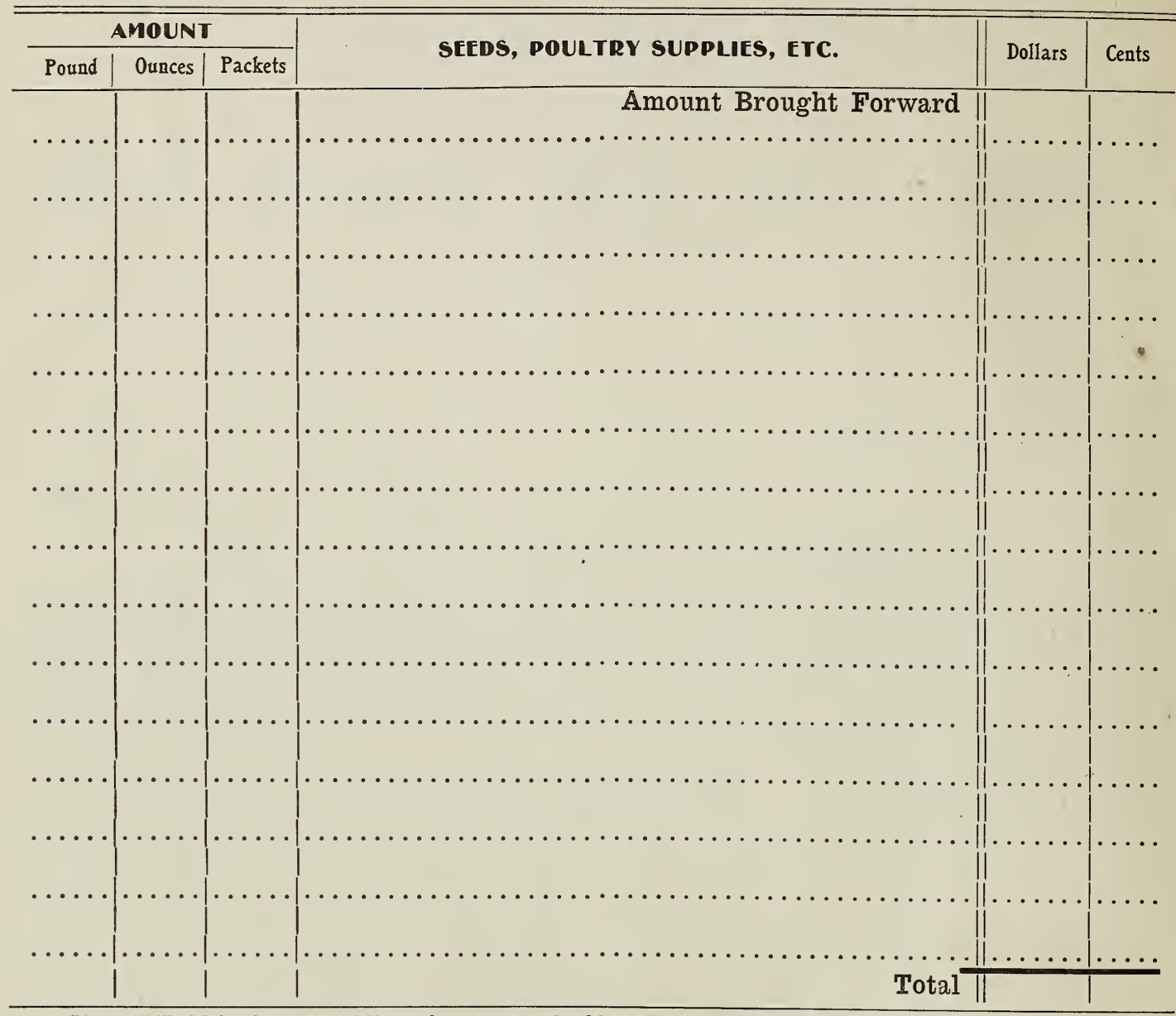

If you will fill in the spaces below, the names and addresses of ten of your neighbors who buy Seeds, Plants,

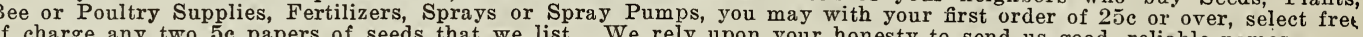
arge any two 5c papers of seeds that we list. We rely upon your honesty to send us good, reliable names.

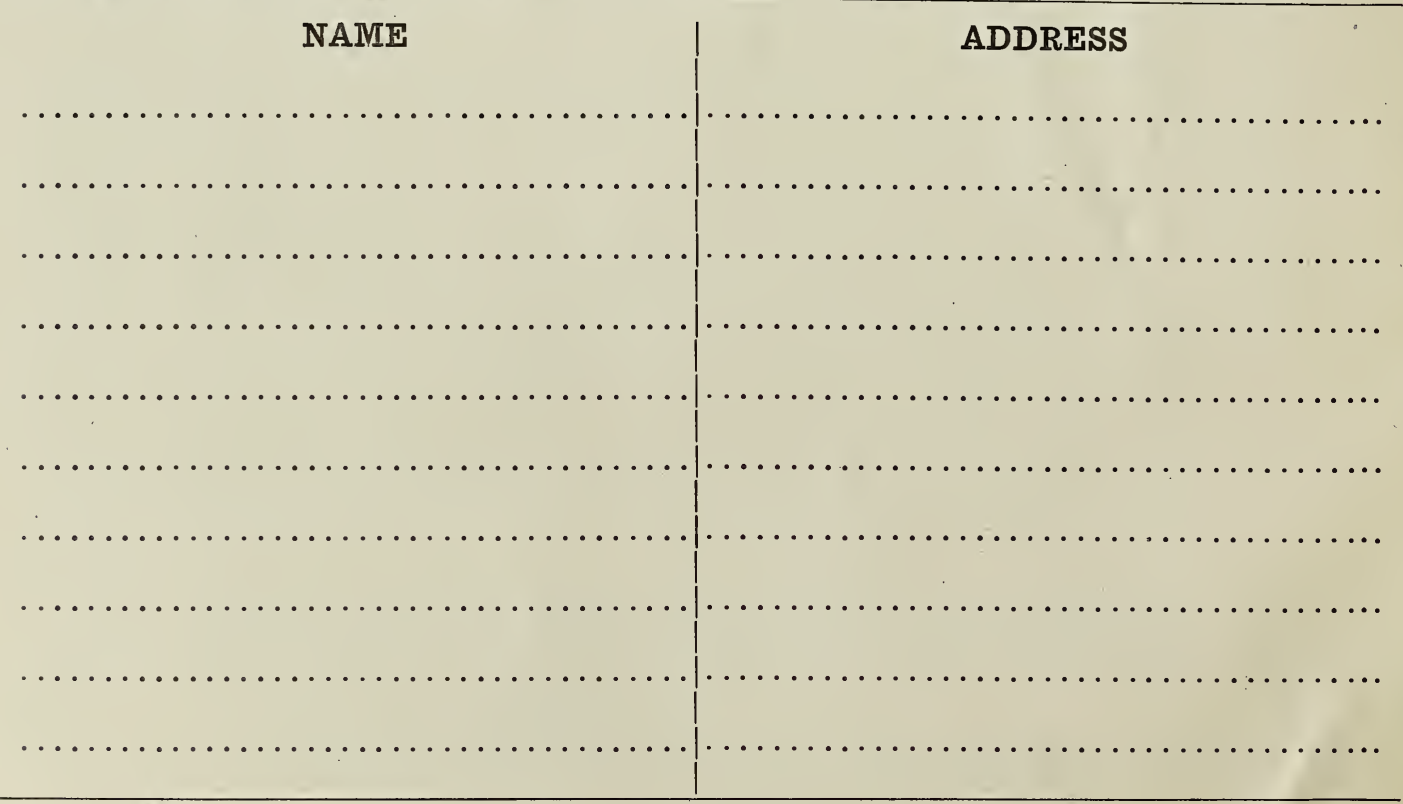




\section{List of Standard Vegetable Seeds}

\section{General Directions for Cultivation \\ ARTICHOKE SEED \\ BEANS}

CULTURE-Sow in April in rich soil and transplant the following spring to permanent beds (in rows or hills) three feet apart and two feet between the plants. Green Artichoke only gives a partial crop the first season, but the beds will be bearing for years. Protect in winter by a covering of leaves or coarse manure.

GREEN GLOBE-Grown for the unripe flower heads, which are highly esteemed by epicures. Large pkt., 10c.

\section{ARTICHOKE TUBERS}

ARTICHOKE TUBERS-Planted and cultivated the same as potatoes. Of great value for feeding stock. They are the best hog feed known. They are remarkable for their fattening properties, oreat productiveness (over one thousand bushels having been raised on one acre) and ease with which they can be grown. If hogs are turned in on them they will help themselves by rooting. One lb., postpaid, $15 \mathrm{c} ; 100$ lbs., \$2.50.

\section{ASPARAGUS SEED}

One ounce will sow 50 feet of drill.

CULTURE-Sow early in spring in rows one foot apart: when one year old the roots may be taken up and transplanted in permanetn beds, which should be made by taking out the soil to a depth of about 16 inches, fill in with 6 out the soll to a depth of about 16 inches, fill in with inches well-rotted stable manure, then six inches of soil inches apart with the roots well spread out and cover so that the crown will be about four inches below the surface. Keep the surface well raked to keep down the weeds until the shoots start.

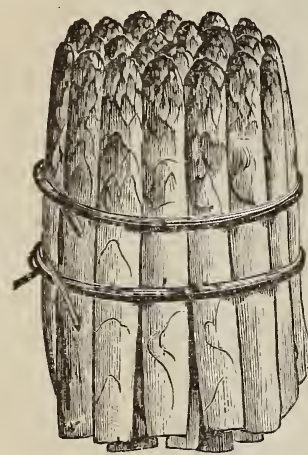

PALMETTO-This variety is of southern origin, very desirable on account of its earliness, bright green color, presenting an attractive appearance, excellent flavor and productiveness. Pkt., Jc; oz.

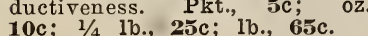
COLUMBIAN MAMMOTH WHITE-A newer, distinct and valuable variety. The stalks valuable variety. The staks very productive and early. Pkt., 5c; oz., 10c; 2 oz., 15c; $1 / 4 \mathrm{lb}$., $25 c$; 1b., 75c.

CONOVER'S COLOSSAIA standard sort; quality first class, spreads less than other sorts. Yields from 15 to 30 sprouts from a single plant. Pkt., 5c; 0z., 10c; 1/4 1b., 20c; lb., 65c.
In ordering by mail add $10 \mathrm{c}$ per $1 \mathrm{~b}$. for postage. Prices in qnantity on request.

CULTURE-Beans should not be planted until the ground is warm, as cold and wet weather will cause the seed to rot. For garden culture plant four or five seeds in hills one foot apart, and the rows eighteen inches apart. For field culture, make the rows three or three and onehalf feet apart, and cover with two inches mellow soil. Do half feet apart, and cover with two inches mellow soil. Do rain, as getting the leaves bespattered with earth causes rust, which injures the crop.

\section{Wax Pod Varieties}

IMPROVED GOIDEN WAX BEAN-This is the favor ite early wax variety, more largely used than any other. The pods are yellow, stringless, large and handsome. Very productive. Large pkt., כoc; lb., 15c; 10 lbs., \$1.25.

PROLIFIC BLACK WAX BEAN-A very early wax podded sort; pods round, stringless and of exceptionally delicate and fine quality. Large pkt., 5c; 1b., 15c; 101b., \$1.25.

WARDWELL'S KIDNEY WAX BEAN-This splendid early variety has a pure wax pod, is entirely stringless, and almost rust-proof, as it holds its pods so high above the ground. Large pkt., 5c; 1b., 15c; 10 lbs., $\$ 1.25$.

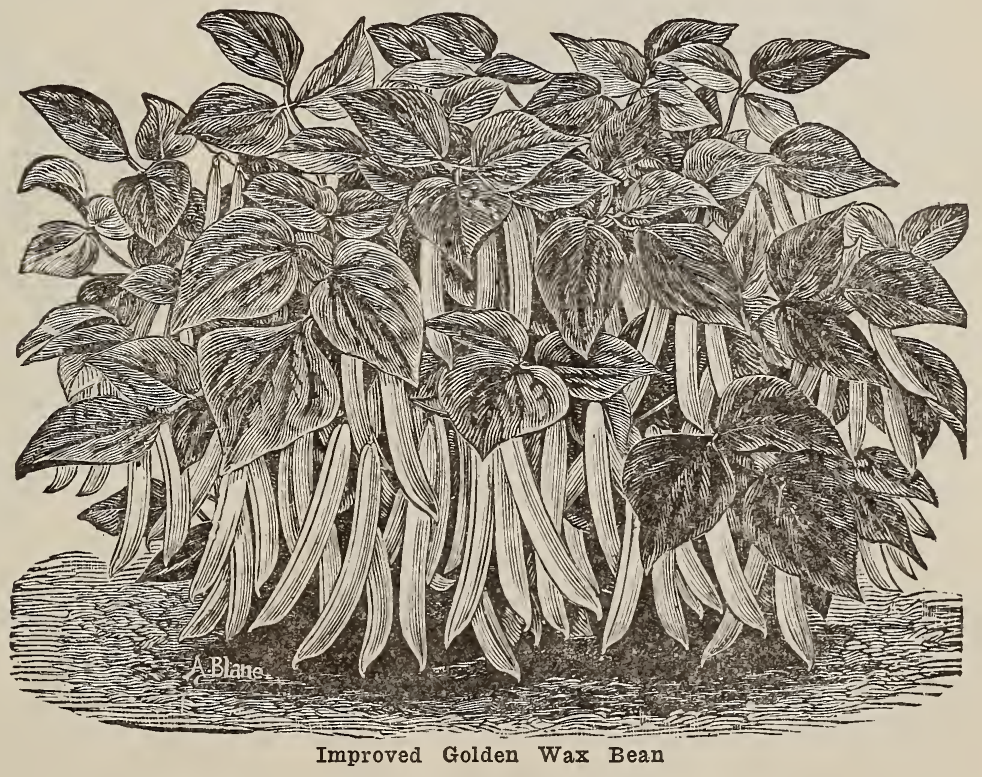

Green Pod'Varieties

EXTRA EARLY ROUND POD RED VAIENTINE-The best green podded, "snap short" bean. The pods are of good quality. this is the most popular of all the green-podded beans. Large pkt. 5c; 1b., 15c; 2 lbs., 25c; 10 lbs., $\$ 1.25$.

NEW STRINGLESS GREEN POD-Long, round, green pods, absolutely stringless; tender, brittle and of finest flavor. While more hardy to withstand frosts, yet it is as tender to cook as any wax pod bean. Early and productive. Pkt., 5c; 1b., 20c; 2 lbs., 35c; 10 lbs., \$1.35. 


\section{(BEANS-Contincued)}

\section{Burpee's Bush Lima}

BURPEE'S BUSH IIMA-The true bush form of the old large Lima Pole Bean. It grows vigorously to a height of 18 to 20 inches, forming a circular bush two or two and a half feet in diameter, requiring no poles or stakes, yielding from 50 to 150 fine pods, similar in size and quality to those grown on large White Lima Beans. Large pkt., 5c; 1b., 20c; 10 lbs., \$1.50.

\section{Pole or Running Beans}

LAZY WIFE-The pods are produced in large clusters in oreat abundance and are from four to five inches in length. Dark green, rather flat but broad, quite thick, fleshy, and entirely stringless, retaining their brittleness until fully developed; of unusually rich flavor. The dry beans are pure white in color; excellent for winter use. Lb., 20c; 10 lbs., \$1.50.

\section{BEETS}

CULTURE-Sow as early in the spring as the ground can be worked and every two weeks thereafter, up to the middle of July. For general crops sow about the twentieth of May. The soil should be deep, rich and mellow, plowed deep and harrowed until very fine. Drop about one inch deen in drills twelve to eighteen inches apart, and when well up thin to four or six inches. The tops of the young beets can be used for greens. One ounce will sow a sixty. foot drill. Six pounds to the acre.

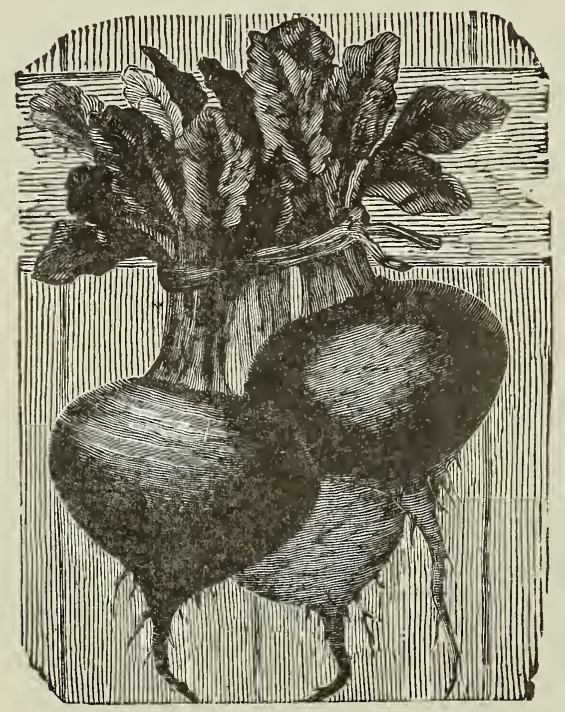

\section{Early Blood Turnip}

EXTRA EARLY EGYPTIAN-The earliest sort; turnip shaped, small, symmetrical, deep blood color. Pkt., 5c oz., 10c; 1/4 lb., 20c; lb., 60c.

ECLIPSE-Makes rapid growth; top small, quality fine, larger than Egyptian, but not as deep a red in color. Pkt., 5c; 0z., 10c; $1 / 4$ lb., 20c; 1b., 60c.

CRIMSON GLOBE-The finest table beet grown. Early, of medium size, uniformly round, color deep crimson throughout, exceedingly tender and sweet and a good keeper. Oz., 10c; $1 / 4$ 1b., 20c; 1b., 60c.

MARKET GARDENER-This new extra early beet is remarkable for its fine quality and rapid growth; is of deep red color and handsome shape, as an early market sort it is unrivaled. It is to a large extent superseding the Egyptian, being earlier in development, more attractive in appearance, and of superior quality for the table. We have never known a market gardener to try it but who wanted it again. Pkt., 5c; oz., 10c; $1 / 4$ lb., 20c; 1b., 60c.
LONDON HORTICULTURAL, OR SPECKLED CRANBERRY - Vines moderately vigorous, with large, light colored leaves and purple blossoms; pods short, broad, pale green but becoming streaked with bright red; beans large, ovate, splashed and spotted with wine red, and of the highest quality, either dry or green. Lb., 20c; 10 lbs., \$1.50.

KENTUCKY WONDER (Old Homestead)-Best variety, round and fleshy, they mature quickly and are of first for use in green state. Enormously productive. Lb., 20c; 10 lbs., \$1.50.

DUTCH CASE KNIFE-Good corn hill bean; very early; pods long and flat; beans, white; used green or dry. Pkt., $10 c ; 1 b ., 20 c ; 10$ lbs., \$1.50.

NAVY BEANS-Price, per lb., 15c; 10lbs., 75c.

LADY WASHINGTON BEANS-Price, per lb., 15c; 10 lbs., $75 \mathrm{c}$

EARLY BLOOD TURNIP-Roots turnip shaped, deep crimson, tender and sweet. Pkt., 5c; oz., 10c; $1 / 4$ lb., 20c; 1b., 55c.

IMPROVED HALF LONG BLOOD-An old and popular variety, especially desirable for autumn and winter use. Pkt., 5c; oz., 10c; $1 / 4$ lb., 20c; lb., 50c.

\section{STOCK BEFTS}

IMPROVED GOLDEN TANKARD-We have for years insisted that this was the best mangle grown, and each succeeding season strengthens us in the position we took when it was a comparatively unknown sort. We recommend it unqualifiedly as the best mangle by far for dairy farmers. oz., 10c; $1 / 4$ lb., 15c; 1b., $40 \mathrm{c}$.

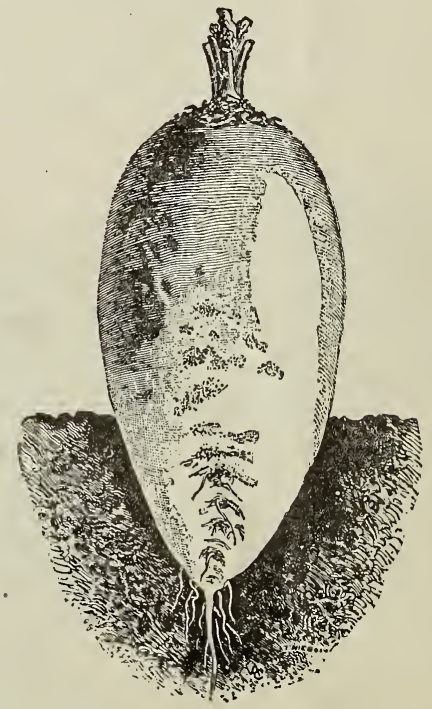

\section{New Mangle, One-Half Sugar}

NEW MANGLE, HALF SUGAR-A new variety, very much more valuable for feeding purposes than the old sorts, it being very much richer. In addition to this, the size and form have been improved until it yields as much per acre as the best Mangles, and twice as much per acre (bulk of roots) as the rich sugar beet seed; is much easier handled, keeps better and is in every way most valuable handled, keeps better and is in every way most valuable
to the farmer. Roots large, ovoid in form, very smooth, with few rootlets; light, pink or rose color, with small top Oz., 10c; 1/4 lb., 20c; lb., $45 \mathrm{c}$.

IMPROVED IMAIMMOTH LONG RED-Our stock is a great improvement on the old variety; the roots are ver large, uniformly straight and well formed; color deep red, roots solid and tops small; roots attain a large size, one being exhibited last year which weighed 58 pounds; produce an immense bulk and tonnage. Oz., 10c; $1 / 4$ lb., 15c; lb., $40 c$. 


\section{(BEETS-Continued)}

\section{SUGAR BEETS}

IANE'S IMPERIAL SUGAR-An improved variety of the French sugar beet, recommended as being hardier, and as containing more sugar: large and excellent for stock. Oz., 5c; $1 / 4$ lb., $\mathbf{1 5 c}$; lb., $45 \mathrm{c}$.

KLEIN WAUZLEBEN - A hardy and earlier grown varity, which is generally acknowledged to be the best to grow for the manufacture of sugar. Oz., 10c; $1 / 4$ lb., 15c; lb. 45c.

\section{BRUSSELS SPROUTS}

Cultivated for the small heads that grow in considerable numbers from the main stem. It is a delicacy much es teemed by some. Sow in seed bed middle of spring and transplant and manage as winter cabbage. Pkt., 5c; oz. 20c; $1 / 4$ ib., 50c.

\section{BORECOLE OR KALE}

The Kales are more hardy than cabbage, make excellent greens for winter and spring use. The small heads to be cooked like spinach.

TALI GREEN CURLED SCOTCH-This is one of the most popular varieties. It is very hardy, and is much improved by frost. Two feet high. Pkt., 5c; oz., 15c; 1/4 1b., 40c.

\section{BROCCOLI}

Sow early in spring. Transplant and cultivate the same as cabbage. The Broccoli is similar to the cauliflower. They will produce heads in October and November, and should any plant not be forward enough for use before severe frosts, let them be removed to a light cellar, where they will head during the winter.

LARGE WHITE MAMMOTH-Pkt., 5c; oz., 35c; 1/4 lb., $\$ 1.00$.

\section{CABBAGE}

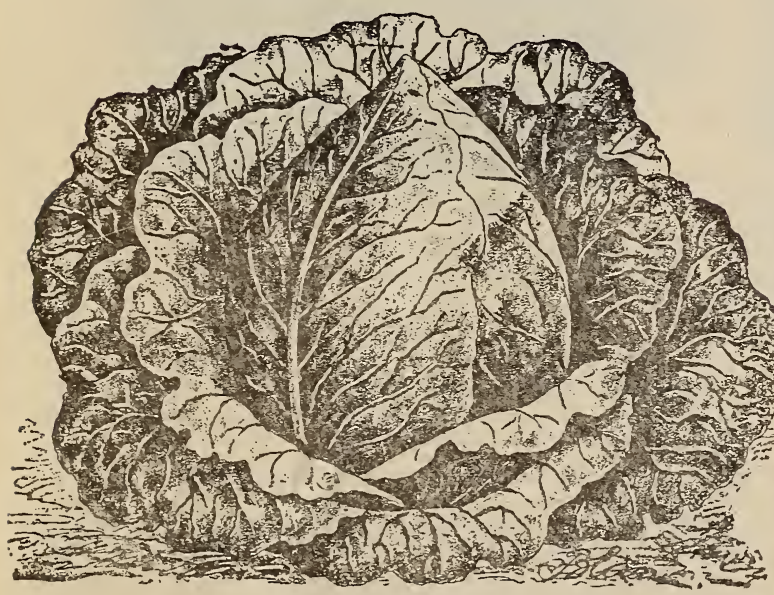

Early Jersey witatield

CULTURE-For early cabbages sow the seed in a hot bed in March or April, covering the seed from $1 / 4$ to $1 / 2$ an
inch deep avd, when big enough, transplant to another bed. As soon as the ground is in good condition transplant, outside, in rows 2 feet apart and 15 to 18 inches in a row. The soil should be mellow, rich and well drained. For late crop the seed can be sowed in a cold frame; or even in the open ground, and then transplanted in rows 3 feet one way and 2 feet the other, so as to be able to work with a hors and cultivator. One ounce of saltpeter dissolved in 3 gal lons of water sprinkled over the cabbage or cauliflower will destroy the green worm. The liquid, being clear, does not collect on the cauliflower or cabbage heads. Fine air slaked lime or tobacco dust, sifted on the roung plants, as soon as the fleas appear on the ground, will provent them from doing any harm. One ounce of seed will produce about 2,000 plants. About 16,000 early or 8,000 late cabbages plant one acre.
First Early Cabbages

EARLY JERSEY WAKEFIELD-The earliest and hardiest heading of extra early cabbages. Most gardeners depend upon it for the bulk of their extra early crop. Heads conical, very compact, solid and of excellent quality. The thick, stout leaves and compact habit make it the best sort for very early setting. Pkt., 5c; oz., 20c; 2 oz., 35c; $1 / 4$ lb., 60c; $1 / 2$ lb. $\$ 1.00 ; 1 b ., \$ 1.75$.

EARLY WINNIGSTADT-A desirable kind, having conical, solid heads; a sure header under almost any conditions, and keeps better than most early varieties. Fine and of excellent quality. Pkt., 5c; 0z., 20c; 2 0z., 35c; 1/4 lb., 60c; lb., $\$ 1.75$.

HENDERSON'S EARLY SUMMER-About ten days later than the Jersey Wakefield. The head is round, and the largest of the early kinds; can be set close in the row as the outer leares are small. It remains long without bursting; is firm and of the best quality. Pkt., 5c; oz., 20c; 2 oz., 35c; $1 / 4$ lb., 65c; lb., \$2.00.

EARLY YORK-Small, but rery early; very popular sort. Can be planted close together. Pkt., 5c; oz., 15c; 2 oz. $25 c$; $1 / 4$ lb., 40c; lb., $\$ 1.50$.

ALI SEASONS-A Drumhead Cabbage as early and every way is good as Early Summer, but yielding heads from a third to a half as large again. This cabbage, while it matures a day or two later in the spring, when planted in July, matures a day or two earlier than Early Summer in the fall, so that it will average as early, while the solid heads are from a third to half as laroe again our earliest cabbages are only good as early cabbages, being too small for late, or too small and too thin to be kep over winter; but the heads of this cabbage being large and also thick through, make it a most excellent variety either for extreme early or for fall or spring market. Pkt., 5c; oz., 20c; $1 / 4$ lb., 65c; lb., $\$ 2.00$.

ALL-HEAD EARLY-It is among the earliest of the large cabbages. It is fully one-third larger than the Early Summer. The deep flat heads are remarkably solid and uniform in color as well as shape and size. tI is very tender and of fine quality. Pkt., 5c; oz., 20c; $1 / 4 \mathrm{lb}$., 65c lb., \$2.00.

\section{Late or Fall Sorts}

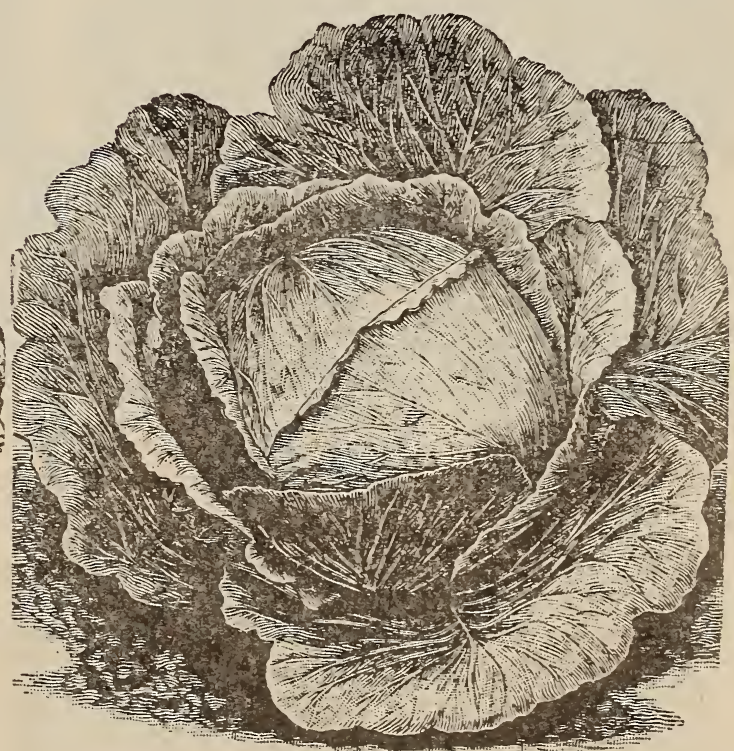

DANISH BALL HEAD.

HOLLANDER, OR DANISH BALL FEAD-This is one of the hardiest cabbes in cultiration, frost and drought that would destroy other varieties. frost and drought that would destroy other varieties.
Plants very hardy, rather long stemmed, but compact; leaves very smooth, but thick; head of medium size, round and rery solid, being the hardiest heading cabbage we know of and of the very best quality. vatures quite late well and is considered by many the best cabbage to hold orer for spring markets. Pkt., 5c; oz., 20c; 2 oz., 35c; $1 / 4$ lb., 60c; lb., \$2.00. 


\section{(CABBAGE-Continued)}

SELECTED - IATE FLAT DUTCH-A low-growing variety: heads large, bluish oreen, round, solid, broad and flat on the top; an excellent fall and winter variety and a good keeper; it is a sure header. Our stock has been grown from carefully selected heads, and we consider it superior to any other strain of Flat Dutch Cabbage on the market. Large pkt., 5c; oz., 20c; 1/4 lb., 60c; lb., \$1.75.

PREMIUM LATE DRUMHEAD-A sure heading sort, which in good, rich soil will grow to an enormous size and on poorer soils will give good sized heads which are very compact, solid and of excellent flavor. Pkt., 5c; oz., 20c; $1 / 4$ lb., 60c; $1 / 2$ lb., \$1.00; lb., \$1.75.

SUREHEAD-A popular sort for main crop; never fails to form uniformly large, solid heads, which are tender and of fine, sweet flavor. An excellent keeper and a good ship. per. Pkt., 5c; 0z., 20c; 1/4 lb., 60c; lb., \$2.00.

DRUMHEAD SAVOY-Fine quality. Pkt., 5c; oz., 15c; $1 / 4$ lb., 50c; lb., \$1.50.

ROCK RED-Best red sort, much used for pickling. Fkt., 50c; 0z., 20c; 1/4 lb., 75c; lb., \$2.00.

\section{CAULIFLOWER}

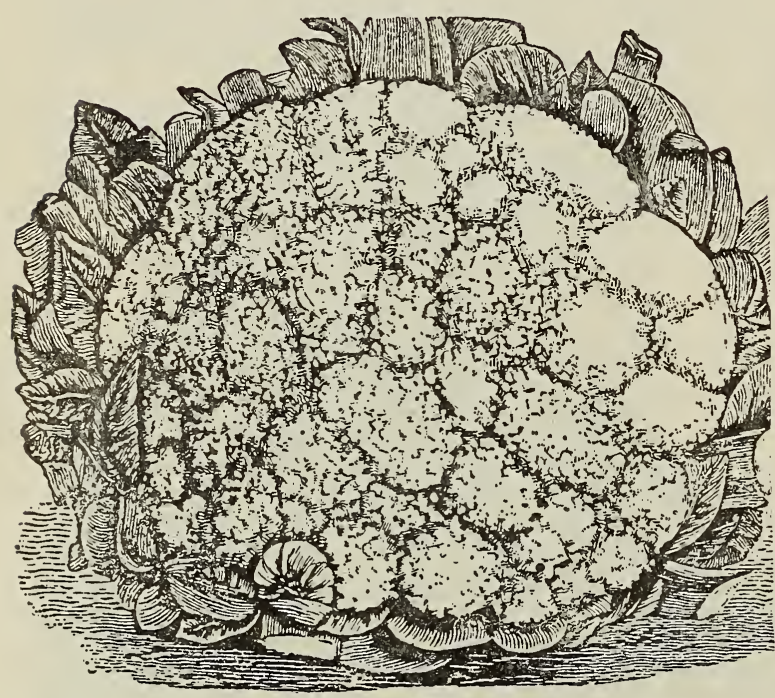

Early Snowball

CULTURE-The soil for cauliflower should be like that for cabbage, but is better if made richer than is ordinarily used for that crop. Give the plants thorough culture and keep free from worms with insect powder. For late crop sow at same time as for late cabbage, and treat in the same manner. tI should be borne in mind that cauliflower will not head up good in hot, dry weather, and hence the sowings should be so regulated as to bring it to maturity either ings should be so regulated as to bring it to maturity either
before the hot summer weather sets in or not until the before the hot summer weather sets in or not until the cooler weather of the fall. If it receives at this time a liberal supply of water, the size and quality of the heads will be greatly improved. After the heads begin to form, draw the leaves over and pin or tie them together to protect the heads from the sun and keep "them," white. The and hard, as they soon become tough and bitter after they open and separate into branches.

EARLY SNOWBALI (Best Imported Strain)-This is an improved extra early strain of dwarf, compact growth. Under favorable circumstances nearly every plant will make a fine, solid head of good size. It is valuable for both early and late. Plat., 5c; $1 / 2$ oz., \$1.25; oz., \$2.25; $1 / 4$ lb., $\$ 8.00$.

Our Snowball Cauliflower Seed is imported direct from growers in Germany.
EXTRA EARLY DWARF ERFURT-Very dwarf, sure to head and one of the earliest. The heads are of good size, pure white, very solid, of excellent quality and delicate flavor. Pkt., 10c; oz., \$2.00.

AUTUMN GIANT-A distinct and valuable late variety. The heads are reasonably large, beautifully white, firm and compact, and being well protected by foliage, remain for a long time fit to use. The plants should be started and transplanted early in the season to insure their full development. Pkt., 5c; oz., 60c; $1 / 4$ lb., $\$ 2.00$.

\section{CELERY}

CULTURE-One ounce will produce about 3,000 plants and sow about 200 feet of row. Sow in light, rich soil in shallow drills, and cover the seed lightly with finely sifted mold. Prick the seedling out into beds of very rich soil, 3 inches apart. Water freely and shade from the sun until established. When the plants are 5 to 6 inches high transplant to rows 3 to 4 feet apart, according to the variety, allowing 8 inches between the plants in the row. Cultivate freely and earth up to blanch the stems, pressing the soil firmly around the plant almost to the top, care being taken not to cover the tops of the center shoots. Remember that this crop well repays generous treatment.

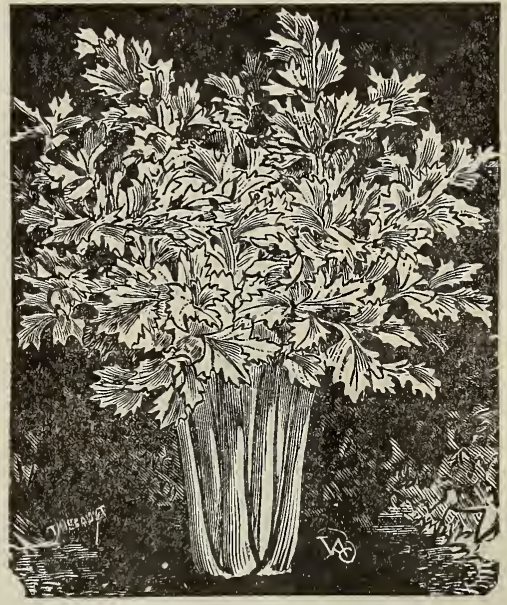

White Plame Celery.

WHITE PLUME-A new variety; popular on account of its naturally white leaf stalks, which require less blanching than the other kinds. Tie the tops together and hill up the earth slightly. Its handsome, plume-like top is very ornamental on the table. It is quite early and a fine market ort. Pkt., 5c; 0z., 20c; 1/4 lb., 60c; lb., \$2.00.

GOLDEN SELF-BLANCHING-A variety somewhat resembling the White Plume, and, like it, requiring but little earthing to secure perfect blanching. It is of a rich, golden tint when ready for the table; very handsome and of excellent quality. Pkt., 5c; oz., 30c; 1/4 lb., 90c; lb., \$3.00.

KALAMAZOO-An erect, compact growing variety. Stalks moderately thick and distinctly ribbed, solid, crisp and of excellent quality. Oz., 30c; 2 oz., 55c; $1 / 4$ lb., $85 \mathrm{c}$.

GIANT PASCAL-A standard sort for later or winter market; large, fine stalks; when blanched, of a deep golden yellow. Pkt., 5c; oz., 20c; 1/4 lb., 50c; 1b., \$1.50.

WINTER QUEEN-It has the strong, robust growth of the Giant Pascal, but the plants being only of medium height, are of better length for bunching for market as well as more desirable for serving on the table. Their compact habit makes considerably less labor necessary in earthing up the plants to blanch and the rows can be planted more closely in the field. Of strong, vigorous growth, each plant. makes a large number of fine stalks (magnificent large heart of rich golden yellow), which are broad, thick and heavily ribbed. Stored for winter it is an excellent keeper, and when taken out the blanched stalks are firm and crisp; entirely free from strings, brittle and of sweet flavor. Pkt., 5c; 0z., 25c; $1 / 4$ lb., 80c; $1 / 2$ lb., $\$ 1.50 ; 1 b ., \$ 2.50$.

CELERIAC, OR TURNIP-ROOTED-Grown exclusively for its roots, which are turnip-shaped, very smooth, tender and marrow-like. The roots are cooked and slieed; used with vinegar they make an excellent salad. Pkt., 5c; oz., 20c: $1 / 4$ lb., 60c. 


\section{CRESS}

A delicate, pungent salad plant, very agreeable alone or mixed with other salads. Enetirely distinct from common cress, thriving only where its roots are submerged. Sow the seed thinly along the banks of any shallow stream early in the spring. It will increase rapidly if the conditions are favorable, and reappear every spring with no further attention.

TRUE WATER-Per oz., 30c; $1 / 4$ lb., $\$ 1.00 ; 1 / 2 \quad l b$. , $\$ 1.75 ;$ Ib., \$3.25.

CRESS, OR PEPPER GRASS-The leaves, when young, have a warm, pungent taste, and are used as a salad, either alone or mixed with other salad plants. The seed germinates quickly, and the plants grow rapidly. As they are milder and more tender when youn, the seed should be sown at intervals of ten to fifteen days, making the first sowing as soon as the ground can be prepared. May be cut several times.

CURLED-The best garden variety. Per oz., 10c; 1/4 1b., 2.5c; lb., 60c.

\section{CARROTS}

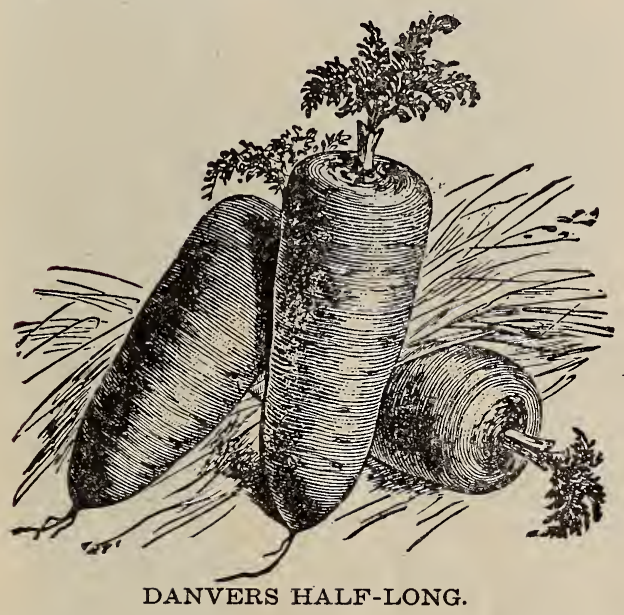

CULTURE-The carrot, like other root crops, delights in a sandy loam, deeply tilled. For early crops, sow in the spring as soon as the ground is in good working order: for late crops they may be sown at any time until the middle of June. Sow in rows, about fifteen inches apart, thinning ottuo three inches between plants. One ounce to 150 feet of drill; three lbs. to an acre.

EARLY SCARLET HORN-A very early variety. Recommended for the market and family garden. Texture fine; very delicate in flavor. Pkt., 5c; oz., 10c; 1/4 lb., 25c; lb. $85 \mathrm{c}$.

HALF LONG SCARLET NANTES-Top medium, finely divided, dark; roots medium, cylindrical, smooth, bright orange; flesh orange, becoming yellow in center, but with no distinct core; finest quality. Pkt., 5c; oz., 10c; 1/4 lb., 25c; lb., 80c.

IONG ORANGE IMPROVED-Very desirable for garden or field culture. Pkt., 5c; 0z., 10c; $1 / 4$ lb., 25c; lb., 75c.

GUERANDE, OR OX HEART-A thick carrot, five or six inches long, and very blunt at the lower extremity. It grows very rapidly and the root attains a weight of more than a pound. It is tender and of good flavor, and a variety that we can recommend to all market gardeners. Pkt., 5c; 0z., 10c; 1/4 lb., 25c; lb., 80c.

CHANTENAY-As a table variety it is first class; in shape it is larger than the Scarlet Horn, and also broader at the shoulder. The flesh is of a beautiful rich orange color and of finest quality. Oz., 10c; 1/4 lb., 25c; lb., 80c

IMPROVED DANVERS HALF LONG-A first-class carrot for all soils; in form midway between the Long Orange and Short Horn. The root is of a rich, dark orange color and grows very smooth and handsome, 20 to 30 tons per acre being not an unusual crop. Pkt., 5c; oz., 10c; per acre being not
$1 / 4$ lb., 25c; 1 b., $80 c$.

\section{STOCK CARROTS}

LARGE WHITE BELGIAN-Grows one-third out of the ground; root pure white, green above ground, with small top; flesh rather coarse; the roots, on light, rich ground, grow to a large size, and are extensively grown for stock feeding. Pkt., 5c; oz., 10c; 1/4lb., 20c; lb., 60c.

MASTODON CARROT-The flesh is white, crisp, solid and very sweet in flavor. It is a vast improvement on the white and green Belgian sorts, which have been favorites in the past, as it is not much more productive, but vastly easier to handle. Oz., 10c; 1/4 lb., 20c; $1 / 2 \mathrm{lb}$., 35c; 1b. 70c.

YELLOW GIANT-This new carrot is half long variety, with an immense broad shoulder. The carrot penetrates less than one-half the depth into the ground. The importance of this point should not be overlooked, as it saves about one-half the expense in the harvesting of the crop. The color is a bright yellow, and is perfection for giving the proper color to your butter. Oz., 10c; 1/4 lb., 20c; lb.,

\section{CUCUMBERS}

For very early Cucumbers, sow the first of April in a hotbed upon pieces of sod (grass side down), so that they can be readily transplanted to the open ground, in rich cail, when danger of frost is over, or protect by hand glasses. For early use, plant, if the weather has become settled and warm, in hills about four feet apart each way; thin out to four of the strongest plants to each hill, after all danger from insects is over; they succeed best in warm, moist, rich, loamy soil; continue planting at intervals for a succession. The Cucumbers should be gathered when large enough to use, whether required or not; if let to ripen, it destroys their prdouctiveness. For pickles, plant from June until the middle of July.

EARLY CLUSTER-A short, prickly variety; usually grows in clusters. Is a prolific bearer, and, except the Early Russian, is the earliest sort flavor excellent. Pkt. 5c; 0z., 10c; 1/4 1b., 30c; lb., 90c.

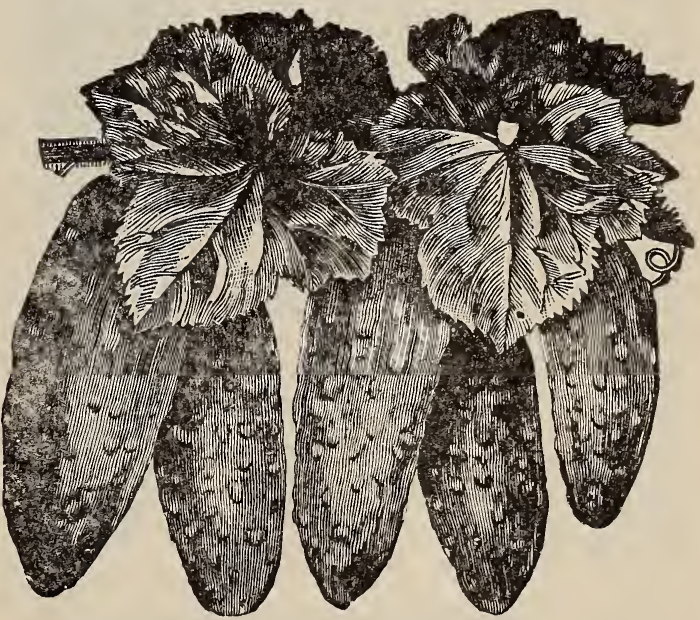

COOL AND CRISP - A strain of the White Spine, but longer and more cylindrical; very early and exceedingly prolific. While it is esteemed most highly as a pickling sort, it is one of the very best for slicing, being tender,
crisp and of fine flavor. Pkt., 5c; oz., 15c; 1/4 1b., 35c; lb., 90c.

EARIY SHORT GREEN, OR EARLY FRAME-A vigorous and productive variety, producing fruit of medium size and regular form; flesh crisp and tender; excellent for the table or pickling when small. Pkt., 5c; oz., 10c; $1 / 4$ lb. table or pick

EARLY WHITE SPINE-One of the best sorts for table use; fruiting early and abundantly; fruit uniformly straight and handsome, light green with a few white spines. Pkt., 5c; 0z., 15c; 1/4 lb., 35c; lb., \$1.00.

LONG GREEN-A popular variety for pickling and slicing. Large pkt., 5c; oz., 15c; 1/4 lb., 35c; lb., \$1.00.

BOSTON PICKLING-This variety is very popular with our gardeners to grow for pickles. Fruit small, smooth, bright green and good quality. A great producer. Pkt., 5c; oz., 15c; 1/4 lb., 35c; lb., \$1.00. 


\section{SWEET CORN}

In ordering by mail add $\mathbf{1 0 c}$ per $1 \mathrm{~b}$. for postage. Prices in quantity on request.

CULTURE-All varieties of sweet corn may be either sown in rows, $4 \frac{1 / 2}{2}$ feet apart, and the seeds planted about eight inches in a row, or planted in hills at a distance of three or four feet each way, according to the variety grown or the richness of the soil in which it is planted. Sweet corn should not be planted deeper than one inch to one inch and a half, as it is liable to rot in the ground. Hoe often, drawing the earth against the stems and break off the side shoots. One quart to 300 hills. About one-fourth bushel will plant one acre in drills.

\section{First Early Varieties}

EARLY MINNESOTA-A splendid and standard variety; ears are good size, the grains sweet and tender. Lb., 15c; 10 lbs., \$1.25.

WHITE COB CORY-An improvement on the Red Cobbed Cory, as well as being equally early. The ears are larger and it has further advantage of having both a white cob and a white grain. A splendid market garden variety, and excellent for the table. Pkt., 5c; lb., 15c; 10 lbs., $\$ 1.25$.

PEEP O' DAY NEW SWEET CORN -Ten days earlier than any other; be disappointed in this New Sweet Corn. Recently introduced. Has pleased everyone who has tried it. For flavor, sweetness and productiveness it is ahead of any other early white it is ahead of any other early white maker for the market gardener, and maker for the market gardener, and a valuable addition to our list of corn
for our short western summers. Lb., $15 \mathrm{c} ; 10$ lbs., \$1.25.

GOLDEN BANTAM-Of extreme hardiness, this can be planted earlier than any other true sweet corn, and will then produce the earliest supply of ears for the table. Planted later of ears for the table. Planted later it does not develop so quickly as Early
Fordhook or Cory, but is vastly supeFordhook or Cory, but is vastly supe-
rior in rich, sweet flavor. By repeated plantings, Golden Bantam alone will furnish a constant supply of the finest ears throughout the entire season. The stalks grow from three and one-half to four feet in height and produce one or two good ears on each stalk The ears are about six inches in length. ears are about six inches in length, completely filled with eight rows of rounded tip. The flavor is exceptionally rich and sugary, "the sweetest of all." Pkt., 5c; lb., 15c; 10 lbs. \$1.25.

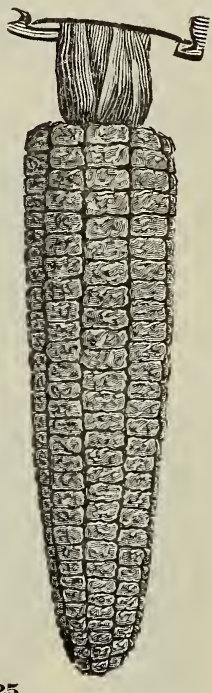

\section{Medium Early Varieties}

FERRY'S NEW EARLY EVERGREEN-As is well known, the famous Evergreen Sweet Corn originated over twenty years ago, but while it is the best variety of late sweet corn, no effort has ever been made to improve it in earliness until now. In the New Early Evergreen we have a selection possessing every good quality of Stowell's Evergreen, and resembling it in every respect, except that the stalk is about one foot shorter, more closely jointed, and that it will mature for market ten to fourteen days earlier. It is certainly a valuable addition to the corn list, and we advise our customers to try this variety. Pkt., 5c; 1b., 15c; 10 lbs., \$1.25.

CROSBY'S EARIY-An early kind, producing well-filled ears of ten or twelve rows. It is remarkable sweet and tender, and considered by many superior to all other kinds. Lb., 15c; 10 lbs., $\$ 1.25$.
BLACK MEXICAN-The sweetest and most desirable for family use. When dry the kernels are black. The corn is not equaled in tenderness and sweetness by any other sort. Pkt., 5c; 1b., 15c; 10 lbs., \$1.25.

PERRY'S HYBRID-An early twelve-rowed variety growing only four to five feet high, with ears as long as the Crosby, and set very low on the stalk. Kernels white, large, sweet and very tender. Lb., 15c; 10 lis., \$1.25.

\section{Late Variety}

STOWELL'S EVERGREEN-The standard main crop variety. Large, well formed ears, deep grained; very sweet and sugary. It is hardy and productive and altogether the best kind for general use. Pkt., 5c; 1b., 15c; $10 \mathrm{lbs}$. \$1.25.

\section{FIELD SEED CORN}

\section{Flint Varieties}

WHITE AUSTRALIAN-Extra early. Hardiest variety known; will thrive at an altitude where the climate is always too cold for ordinary corn; a great drouth resister. Lb., 10c; 3 lbs., 25c; 100 lbs., \$4.00.

\section{Dent Varieties}

MINNESOTA KING (1 $1 / 2$ Dent, Home Grown) -Recommended by the Agricultural College as the best variety for Western Oregon and Washington. Smallest cob and longest grain. The ears are uniformly well filled out, and it will make more shelled corn to a given bulk of ears than any other variety. It is a beautiful golden yellow and a good yielder. Nearly every variety of corn has been tried here and this has so far proven the best. It makes good fodder, and by using the home-grown seed it is sure to ripen. Lb., 10c; 10 lbs., 60c; 100 lbs., \$3.25.

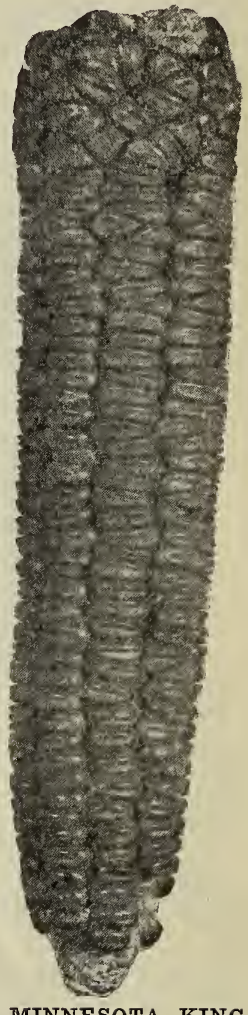

MINNESOTA KING

PRIDE OF THE NORTH (Yellow Dent) - A very early Dent variety, thriving where there are cold, short sum mers. Ears and kernels handsome yellow. Will mature in ninety days. We recommend this variety to our customers. Lb., 10c; 10 lbs., 60c; 100 lbs., \$3.25.

CHAMPION WHITE PEARL-This is used more extensively in the East than any other, and, in our estimation, is very much the best of all the fodder or ensilage sorts. It grows to a height of 12 to 15 feet, according to soil and climatic conditions, yielding an enormous tonnage of fodder, and is exceedingly succulent. Lb., 10c; 10 lbs., 60c; 100 lbs., \$3.25. 


\section{Pop Corn}

WHITE RICE-The best corn for popping and for the general market; early. white pointed kernels. Lb., 15c; 2 lbs., 25c; 10 lbs., \$1.00.

\section{ENDIVE}

ENDIVE-A desirable salad when bleached by exclusion from the sun. Pkt., 5c; oz., 15c; 1/4 lb., 40c; 1b., \$1.25.

\section{EGG PLANT}

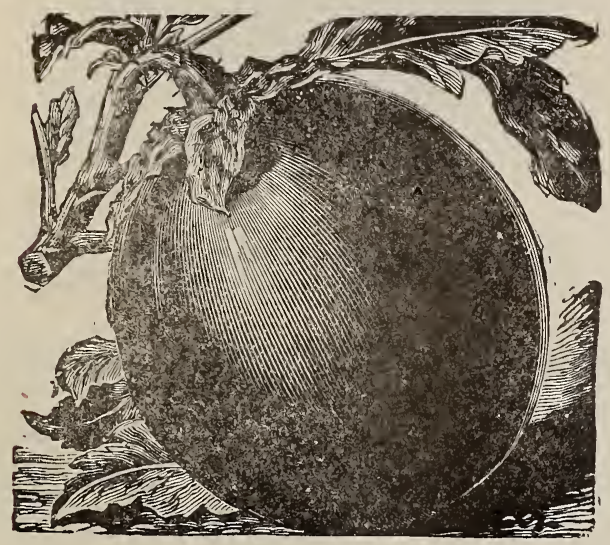

Improved New York Purple Egg Plant.

CULTURE-Sow in hotbeds very early in the spring; thin them out as soon as big enough to be handled to 3 or 4 inches each way, and transplant to 2 or 3 feet apar in very rich, warm ground. Do not plant them outside till nights are real warm, as the least frost will, if it does not kill them, check the growth, and it will take two or three weeks before they get over it. Hoe often and hill up gradually till they blossom. One unce to 1,500 plants.

\section{Improved New York Egg Plant}

NEW YORK IMPROVED-This variety has about superseded all others, both for market and home garden; a favorite everywhere. Our stock is extra selected direct from the best growers in New Jersey. Pkt., 5c; 1/4 0z., 15c; $0 z$. $40 \mathrm{c} ; 1 / 4$ lb., $\$ 1.25$.

BLACK PEKIN-Round, dark purple fruit. Large pkt., 5c; oz., 30c; 1/4 lb., \$1.00.

\section{GOURDS}

NEST EGG-The fruits when ripe exactly resemble hen eggs in shape and color, and are much used as nest eggs. It is also an attractive ornamental climber. Pkt., 5c; oz., $10 \mathrm{c}$.

DIPPER-Useful for many purposes. The capacity varies from a pint to a quart, with handles six to twelve inches long. Pkt., 5c; oz., 10c.

HERCULES' CLUB-Ä very long sort, very thick and heavy at one end, tapering gradually to the stem. Pkt., 5c; oz., 10c.

\section{KOHL-RABI}

\section{Or, Turnip-Rooted Cabbage}

The Kohl-Rabi is a vegetable intermediate between the calobage and turnip, and combines the flavor of each. The edible part is a turnip-shaped bulb, formed by the enlargement of the stem. When used for the table this should be cut when quite small, as it is then very tender and delicate, but if allowed to reach its full size it becomes tough and stringy.

EARLY WHITE VIENNA-The earliest and best for forcing; very tender; excellent for table use. Pkt., 5c; oz., 20c; lb., 60c.

\section{LETTUCE}

CULTURE-The early sowing may be made under glass, in January and February, keeping the plants thin and admitting plenty of air every fine day. For a succession, outside, sow every two weeks. as soon as the ground is open, in drills one foot apart, covering the seed about one-quarter of an inch deep and thinning out to 6 or 8 inches in the row. For a cut salad sow thicker and do not thin out. They do best in rich and moist soil. One ounce to 3,000 plants.

IMPROVED HANSON-We have a very fine stock of this rariety, and can recommend it as one of the best on our list. It is a fine heading variety of the largest size; solid, sweet, tender and crisp throughout, and entirely free from any bitter taste; for home use one of the best lettuces known. Pkt., 5c; 0z., 10c; 1/4 lb., 30c; lb., \$1.00.

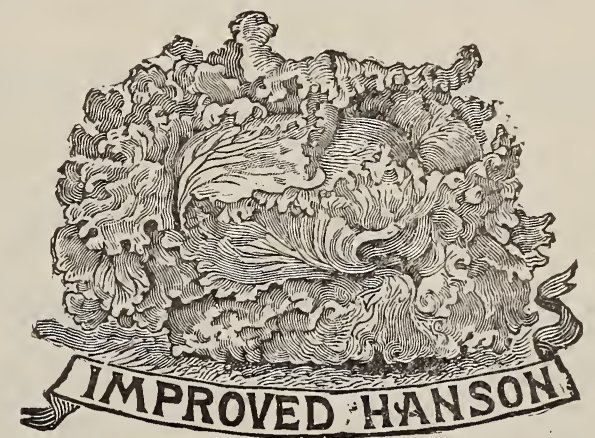

DENVER MARKET-It is an early variety of Head Lettuce either for forcing or open ground. It forms large, solid heads of a good light green color, and is very slow to go to seed. The leaves are beautifully marked and blistered and very crisp and tender and of excellent fiavor. By these blistered leaves it distinguishes itself from any other kind of lettuce now grown. The shape of the head resembles of lettuce now grown. The shape of the head resembles gromewhat the Hanson, but is more oblong. This stock is the true stock. Pkt., 5c; 0z., 10c; 1/4 lb., 30c; lb., \$1.00.

GRAND RAPIDS (Seed Black)-As a lettuce for greenhouse forcing, this variety undoubtedly stands at the head of the list, being of quick growth, little liable to rot and standing for some days after being ready to cut. The plant is upright and forms a loose head or cluster of large, bright leaves, slightly crimped and blistered and rather thin. The leaves do not wilt quickly after cutting, so that the variety will stand shipping long distances better than most sorts. Pkt., 5c; oz., 10c; 1/4 lb., 30c; 1b., \$1.00.

MAY KING (Seed White) - A large, light green heading lettuce of excellent quality and desirable for growing either under glass or outdoors, where it matures the earliest of any. Pkt., 5c; oz., 15c; 1/4 lb., 40c; 1b., \$1.25.

ICEBERG-Has an unusually solid head. The white main ribs of the leaves curve toward the center, which keeps the interior thoroughly bleached. It is quick growing and always crisp and tender, whether propagated in early spring or in the hot days of summer. Pkt., 5c; oz., 10c; $1 / 4$ lb., 30c; lb., $\$ \mathbf{1 . 0 0}$.

CRISP-AS-ICE-It is a beautiful lettuce of the cabbage type. The solid heads are of great size, and leaves so tentype. The solid heads are of great size, and leaves so tender and brittle as to have suggested the name bestowed
upon it. The head has a rich, yellow heart. The leaves are upon it. The head has a rich, yellow heart. The leaves are green color, variegated with bronze. This lettuce cannot be overestimated or overpraised for home use in spring and summer. Pkt., 5c; 0z., 10c; 1/4 lb., 30c; 1b., \$1.00.

PRIZEHEAD (W. S.) - Large, loose-headed sort, the leaves are tinged with brown, very heavy. Pkt., 5c; oz., $10 \mathrm{c} ; 1 / 4$ lb., 30c; 1b., \$1.00.

EARLY CURLED SILESIA-One of the best curled varieties, either for forcing or for early sowing out of doors. Very popular with market gardeners and private planters. Pkt., 5c; 0z., 10c; 1/4 lb., 30c; lb., \$1.00.

BLACK-SEEDED SIMPSON-Very large, loose heads of curly, golden-yellow leaves, which are thin and tender. It stands summer heat splendidly and is valued for frame culture. Pkt., 5c; oz., 10c; $1 / 4$ lb., 35c; 1b., $\$ 1.00$. 


\section{LEEK}

One ounce will sow 100 feet of drill.

LARGE LONDON, OR SCOTCH FLAG-This leek is reported more delicate than the onion for soup, etc. Sown in seed bed middle of spring; when the plants are three or four inches high, transplant them into rows wide enough apart to admit the hote between them. With good culture they may be grown five or six inches in circumference. Pkt., 5c; oz., 15c; 1/4 lb., 45c; lb., \$1.30.

\section{MUSTARD}

Used alone as "greens", or with cress as salad. . Sow any time in the spring, in rows, and thin out as necessary.

SOUTHERN GIANT CURLED-We offer a very fine strain of the true curled leaf. Pkt., 5c; oz., 10c; 1/4 1b., 60c.

WHITE ENGLISH_Leaves mild and tender when young; seeds yellow. Pkt., 5c; oz., 10c; 1/4 lb., 15c; lb., 35c.

\section{IMUSHROOII SPAWN}

With intelligent care and good spawn, Mushrooms can be made to pay handsomely. They can be successfully grown in a dry cellar, under the benches of a greenhouse, or in sheds, where the temperature can be kept from 50 to 60 degrees through the winter. Our free pam phlet gives general instruction.

IAMBERT'S PURE CULTURE -A new kind of spawn, without a doubt the best; much superior to doubt the best; much st comes in the common english. It comes in bricks, weighing about 20 ounces. These are broken up into pieces the size of a walnut and put into the bed one foot apart each way. White, cream, brown or light brown. Per brick, 25c; postpaid, 35c; by express, not prepaid, 5 bricks, \$1.00.

\section{MUSK IMELON}

CULTURE-Musk Melons do best on newly broken sod or prairie land, or on soil prepared by plowing under a crop of rye or wheat in the spring. The seed should not be planted until the soil has become thoroughly warmed, about corn planting time. Plant five or six seeds to the hill in hills four to six feet apart. Rich soil or well rotted manure should be used in the hills; when the plants are of sufficient size, thin out to three vines to the hill. After the vines have grown about a foot long, pinch off the ends; this will cause them to become stronger and to throw out branches.

\section{Green-Fleshed Varieties}

HACKENSACK EXTRA EARLY IMPROVED-A selection from and an improvement on the old Hackensack, and similar in shape and appearance; nearly as large and fully ten days earlier; one of the finest for market gardeners; quality perfect. Pkt., 5c; oz., 15c; 1/4 lb., 35c; lb., \$1.00.

EARLY PROLIFIC NUTMEG-Fruit of medium size, slightly ribbed, globular. Skin dark green, becoming yellow when overripe, and nearly covered with broad, shallow netting. Pkt., 5c; oz., 1.5c; 1/4 lb., 35c; lb., \$1.00.

BANANA-Melons very slender, and two or three feet long. A very fragrant variety, and if not picked until thoroughly ripe, of very good quality. Its flesh and flavor, as well as its shape, remind one of a great, luscious banana. Pkt., 5c; oz., 25c.

PEACH OR GARDEN LEMON-The fruit is about the size of a large peach, oval shaped and of a bright orange yellow color, somewhat russetted. When it first ripens it is quite hard and has very little flavor, but they soon become mellow, not sweet, and have a rich flavor. For sweet mellow, not sweet, and have a rich flavor. For sweet
pickles, pies or preserving they are superb. Pkt., 5c; oz., 25c.

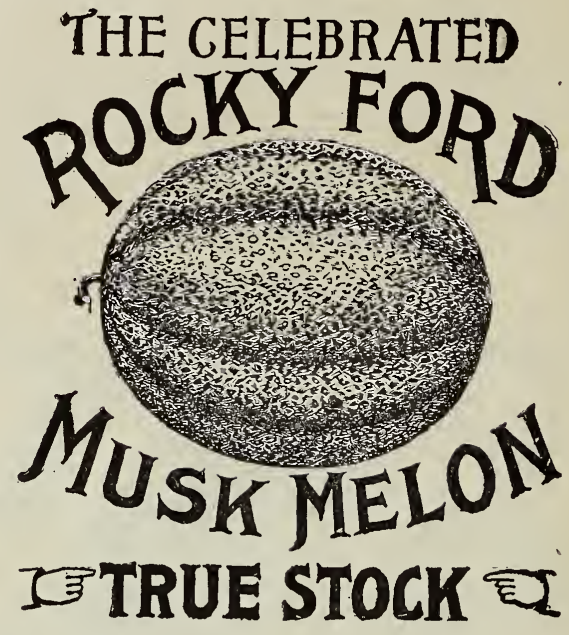

THE ROCKY FORD MUSK MEION-Is a new and most valuable introduction, and has attained in an incredibly short time a national reputation. It is of the Netted Gem type, oval in shape, averaging from four and one-half to five inches in length, of a delicious flavor, very fine and smooth grained flesh, of a light green color throughout when ripe. From the district in which it has been for the past several years so extensively grown, Rocky Ford, Colorado, and from which point these melons are shipped in their season by the carload to nearly every station in the United States, till the name Rocky Ford has become a syno. nym for excellence in cantaloupes. Pkt., 5c; oz., 15c; 1/4 lb., 35c; $\$ 1.00$.

\section{Salmon-Fleshed Varieties}

EMERAID GEM-This is a new variety of excellent quality; it is of medium size. The skin, white-ribbed, is perfectly smooth and of a deep emerald green color. The flesh is thick and of a suffuse salmon color, and ripens to the green rind. It is peculiarly crystaline in appearance, and so very juicy and rich that it almost drops to pieces when dipped out with a spoon. The flavor is very sweet and luscious. The vines are hardy and very prolific, and the melons mature extremely early. Pkt., 5c; oz., 15c; $1 / 41 \mathrm{lb}$., 35c; 1b., \$1.00.

OSAGE-The great ${ }^{*}$ popularity which this melon has attained is due mainly to its peculiar luscious, spicy flavor and its perfect shipping qualities. The skin is very thin,
of a dark green color and slightly netted. The flesh is of a salmon color, remarkably sweet, extremely thick, and delicious to the rind. It is also very productive. It is a remarkable keeper, ani will stand shipping. Pkt., 5c; oz., 15c; $1 / 4$ lb., 35c; lb., \$1.00.

PAUL ROSE-A new variety. A successful cross between the Osage and Netted Gem. It combines the sweet-
ness of the former with the fine netting of the Gem, and is ness of the former with the fine netting of the Gem, and is
even a better shipper than that variety. The melons grow uniform in shape and size. The flesh is remarkably thick, making the melons very solid and heavy, and of a beautiful salmon or orange color; deliciously sweet and melting. Pkt., 5c; 0z., 15c; $1 / 4$ lb., 35c; lb., \$1.00.

\section{Rocky Ford Musk Melons are al-} ways nice. You make no mistake in growing Rocky Fords. 


\section{WATER MELON}

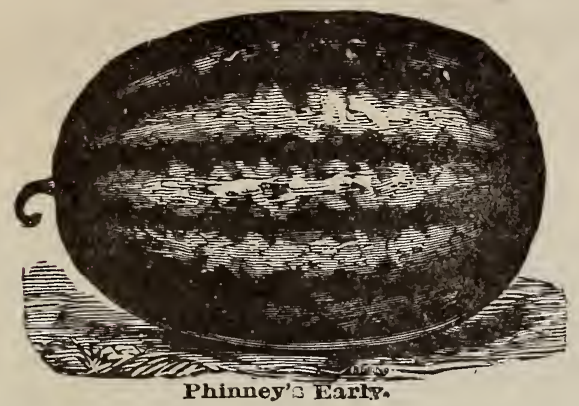

PHINNEY'S EARLY-Tery early, quality good, and while not as sweet as some of the other extra early sorts, is very hardy, and on that account very desirable for culture in sections where the nights are cool. Large pkt., 5c; oz., 10c; 1/4 lb., 25c; 1b., 70c.

KLECKLEY'S SWEETS, OR MONTE CRISTO-TVe regard this as the finest of all the medium-early watermelons for home use. The rind is too thin and tender to stand long distance shipment. The fruits are uniform. Pkt., 5c; 0z., 10c; $1 / 4$ 1b., 25c; Ib., SOc.

HALBERT HONEY-A new, exceedingly sweet and deliciously flavored melon, similar in size and shape to Kleckley's Sweets, but of more regular form and much more productive. It is of handsome, long, oval shape, averaging about 18 inches in length and about 6 inches in diameter. The skin is an attractive, very dark green; the flesh is of a beautiful bright red, extending almost to the outer rind; is very tender and melting, and entirely free from stringiness. The rind, too is so thin and brittle that it cracks open very easily and will not stand hauling or shipping long distances. For home use and nearby markets it ping long distances. For home use and nearby markets it 10c; 0z., 20c; 1/4 lb., 40c; lb., \$1.00.

FORDHOOK EARLY-An extra early watermelon of large size. Attain an average weight of 30 pounds. The rind is tough, making it desirable for shipping purposes. Flesh is light red and is very sweet. Oz., 10c; $1 / 4$ 1b., 25c; lb., soc.

ICE CREAM, OR PEERLESS-One of the best melons in cultivation. Rind thin, light mottled green. Flesh bright scarlet; solid to the center; sweet as honey. Large pkt., 5c; oz., 10c; 1/4 1b., 25c; 1b. 75c.

MCIVER'S WONDERFUL SUGAR-This is becoming the most farored melon for sweetness and high quality. The fruits are long and of large size, averaging about 35 pounds each. It is considered one of the handsomest melons ever sent out, being light colored, irregularly striped and mottled with dark reen. The rind is rather thin but tough. mottled with dark green. The rind is rather thin, but tough. so that it is a good shipper. Flesh is delicate light red, that can be imagined. The vine is a strong, vigorous grower, very prolific and withstands the extremes of weather, either wet or dry. Enthusiastic melon growers unite in pronouncing this the finest quality of any melon grown. Pkt., 5c; 0z., 10c; 1/4 1b., 25c; 1b., 75c.

FLORIDA FAVORITE-Oblong in shape, growing to a very large size; rind dark with light green stripes; flesh light crimson, crisp and deliciously sweet. Pkt., 5c; oz., 10c; $1 / 4$ 1b., 25c; 1b., 75 c.

KENTUCKY WONDER-In shape it is oblong; skin dark green; marbled in stripes of light green; the flesh a beautiful scarlet color, crisp, tender, rich and sugary flavor: always firm and never mealy. Attains an average weight of 40 to 60 pounds. Not a mammoth variety, but a real good old-fashioned Kentucky melon that has few equals in quality. Pkt., 5c; 0z., 10c; $1 / 4 \mathrm{lb}$., 25c; lb., $75 c$.

CITRON-For preserving; grows uniformly round and smooth; striped and marbled with light green; flesh white and solid. Pkt., 5c; 0z., 10c; $1 / 4$ lb., 25c; lb., S0c.

\section{ONION SEED}

CULTURE-Onions do best on a rich loam, previously cultivated for two years. Stiff clay and light sand are equally unfavorable. The land should be highly fertilized with well-rotted manure, complete fertilizers, etc. Fresh stable manure has a tendency to produce soft onions. Drill in four or five pounds of seed per acre, one-half inch deep. If sets are wanted, use 60 to 80 pounds per acre. Six to ten bushels of sets will plant an acre. Fine, marketble size onions (according to variety planted) are easily produced the first year from early spring sown seed. Culture should be frequent though shallow. The same ground may be used for onions, season after season, if well fer may be used for onions, season after season, if well fer tilized annually. Bone meal is an excellent fertilizer
Winter storage demands dryness and protection from sudden changes. Onions should never be handled while frozen.

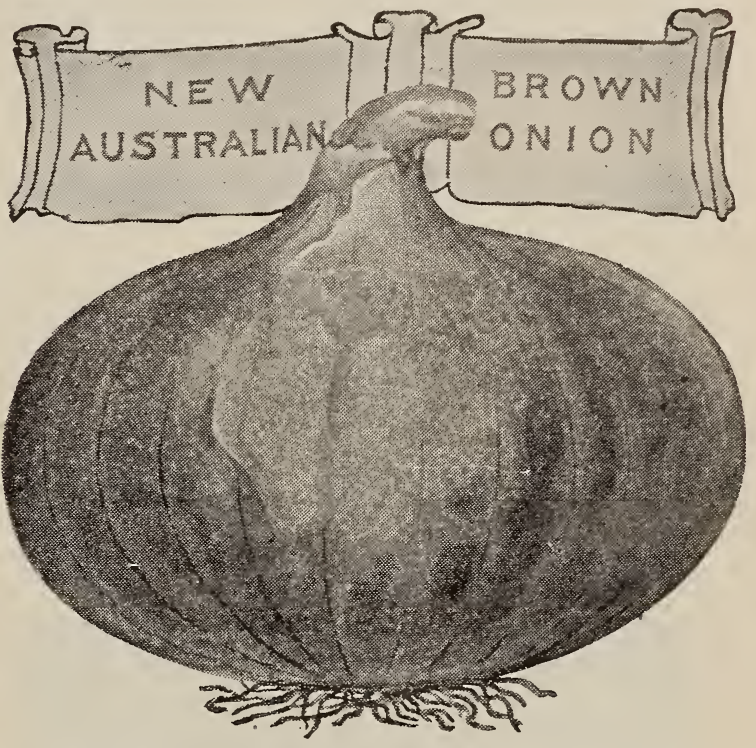

YELLOW DANVERS-The leading large yellow kind, round, slightly flattened, flesh fine-grained, rather mild, very rich and sweet; one of the best keepers and shippers, and one of the most productive kinds. Pkt., 5c; 0z. 20c; 1/4 1b. 65c; 1 b.. \$2.10.

YELLOW GLOBE DANVERS-This is the standard variety for winter use, producing well-ripened bulbs averaging two inches in diameter and nearly globe shaped. Skin a light golden brown or pale yellow; flesh pure white, crisp and mild in flavor. Pkt., 5c; oz., 20c; 1/4 1b., 65c; 1b., $\$ 2.10$.

OREGON YELLOW DANVERS-It is a cross between the flat and the globe, one of the best keepers for our western climate. Plkt., 5c; 0z., 25c; 1/4 lb., 70c; lb., \$2.25.

MAMMOTH PRIZE-TAKER-Genuine seed of this variety produces the handsomest, largest Yellow Globe onion in the list. The yield per acre is larger than that of any other variety. Pkt., 5c; 0z., 25c; 1/4 lb., 85c.; 1b., \$2.50.

AUSTRALIAN BROWN ONIONS-Are of medium size, though growing quite laro under favorable conditions. Wough growing quite large under favorable conditions. for market, both as to form and appearance. Pkt., 5c; oz., 20c; $1 / 4$ lb., 65c; 1b., $\$ 2.10$.

EXTRA EARLY RED FLAT-Deep red in color; resembles the Red Wethersfield, except that it is much earlier and somewhat smaller; desirable for early market. Pkt., 50c., 0z., 20c; 1/4 lb., 65c; lb., \$2.10.

LARGE RED WETHERSFIELD-The standard red variety. Bulb large and somewhat flattened, oval-shaped; skin deep purple red; flesh purplish white, moderately fine grained and rather strong flavor. Very productive. Oz. 25c; $1 / 4$ lb., $75 c$; 1b., \$2.25.

Write for prices in quantity 


\section{[ONION SLED-Continaed]}

WHITE GLOBE-A handsome, white, globe-shaped variety; flesh fine, very white, rich and sweet; it is also one of the best keepers of the silver-skinned kinds. Pkt., 5c; oz., 35c; 1/4lb., \$1.00; 1b., \$3.50.

WHITE PORTUGAL, OR AMERICAN SILVERSKINProduces early onion of mild flavor; largely used for growing sets and pickles. Large pkt., 5c; oz., 35c; $1 / 4$ lb., 90c; lib., \$3.00.

WHITE QUEEN-Remarkable for its earliness and mild flavor it is small and white-skinned; the leading variety for pickling purposes. Pkt., 5c; oz., 25c; $1 / 41 \mathrm{lb} ., 75 \mathrm{c}$; 1b., $\$ 2.25$.

BERMIUDA ONIONS-These onions grow to an immense size and are of beautiful form. The skin is very thin: flesh white, fine-grained, of mild and pleasant flavor. It will grow an onion from one to one and a half pounds from seed, but to attain full size, set out the bulbs the following spring. Pkt., 5c; 0z., 35c; 1/4 lb., 90c; lb., \$3.00.

\section{Onion Sets}

BOTTOM ONION SETS-These are the product of seed and are used for "green onions," or to produce large onions, which they do much quicker than they can be grown from seed. Lb., \$5c, postpaid.

\section{OKRA OR GUIMBO}

The pods sliced are esteemed for soups, stews, etc., and whether used green or dried, must be gathered when young.

WHITE VELVET, HENDERSON'S-Large, round, smooth pods; never ridged; prolific. Pkt., 5c; oz., 10c; $1 / 4$ lb., 20c.

\section{GARDEN PEAS}

We pay postage on peas in 5c packages only. If ordering in larger quantities by mail, add $\mathbf{1 0 c}$ per pound for postage.

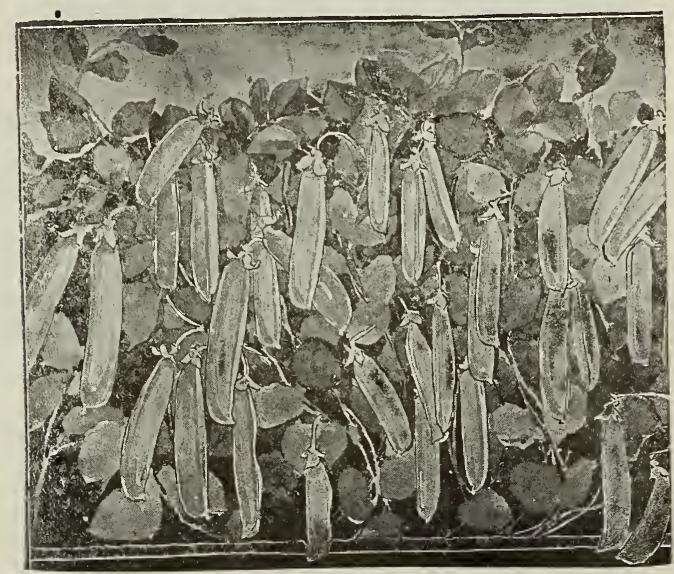

2 lbs. for 100 feet of drill; 2 to 3 bus. in drills per acre.

CULTURE-Sow early in the spring in rows 18 to 24 inches apart. The peas will give quicker returns if covered only 1 inch deep, and where earliness is the most important, they may be treated in that way, but longer pods and more of them will be produced if the seed is planted in trenches 3 to 6 inches deep and covered with one or two inches of soil. When the plants are 5 or 6 inches high, fill the trench level with the surface. Sow every two weeks for succession. For field culture, they may be sown broadcast and plowed under.

\section{Extra Early Peas}

ALASKA, OR EARLIEST OF ALL-Earliest and best of all the blue smooth varieties. A smooth, blue pea, which in evenuess of growth of vine and early maturity of pods is unequaled by any other extra early pea. Vines two to two and one-half feet high, unbranched, bearing four to seven long pods, which are filled with medium-sized, bright green peas of excellent flavor. A great favorite with our market gardeners for fall and early spring planting. Pkt., 5c; 1b., 15c; 10 lbs., \$1.20.

MCLEAN'S IITTLE GEM-A sweet, wrinkled pea, coming in a little later than the American Wonder; grows taller and ocntinues in bearing longer. The quality of the pea is very superior. Height, 15 inclies. Pkt., 5c; 1b., 15c; 10 lits., $\$ 1.25$.

NOTT'S EXCELSIOR-The best early dwarf pea. It combines to a wonderful degree the good qualities of the American Wonder and Premium Gem peas. The vines are larger and more productive than American Wonder and earlier than Premium Gem. The peas, in sweetness and quality, are unsurpassed. The most desirable sort for the market gardener and unexcelled for the home garden. Very hardy. It outyields them 20 to 30 per cent. The pods are onethird longer, and each pod contains from six to nine peas, which are usually fine flavored and tender. Pkt., 5c; lb., $15 \mathrm{c} ; 10$ lbs., $\$ 1.25$.

AMERICAN WONDER-The earliest and best of the wrinkled sorts. A great favorite for family use. Has stout, branching vines, about nine inches hign, and covered with well-filled pods, exceedingly sweet, tender and well flavored peas. Dry peas, medium size, much wrinkled and flattened, pale green. Pkt., 5c; lb., 15c; $10 \mathrm{lb} ., \$ 1.25$.

GRADUS-This extra early wrinkled pea bears pods of large size, and combines quality with earlieness. It is very hardy; can be planted fully as early as the smooth peas; grows vigorous and healthy; vines two and a half feet in height; very prolific. The quality and flavor are delicious, and the peas remain tender and sweet for a long time. Pkt., 5c; 1b., 15c; 10 lbs., \$1.25.

\section{Second Early Sorts}

TELEPHONE-Produces those handsome long pods. A great favorite with our market gardeners. Immensely productive, of the finest quality and excellent, sugary flavor vines very strong; the pods are of large size, filled with large, delicious peas. Height, four feet. Pkt., 5c; 1b., 15c; 10 lbs., \$1.25.

CHAMPION OF ENGLAND-Very rich and fine flavored; very productive; wrinkled. Height, four to five feet. Pkt. 5c; 1b., 15c; 10 lbs., $\$ 1.25$.

STRATAGEM-One of the best of the large, podded peas; the pods are of immense size, filled with large, dark green, wrinkled peas of the finest quality; vine of medium height, but very stocky with broad, light green leaves, and bearing an abundance of large, handsome pods. Pkt., 10c; 1b., 15c; 10 lbs., \$1.25.

PROLIFIC-This is a grand new pea, the seed stock being recently imported from France. It is a robust grower, producing in astounding profusion large, handsome, deep green pods closely packed with luscious, tender, sweet peas. A grand medium early pea for the home and market garden. Height, two feet. You will not be disappointed in the new variety. Try a packet, at least. Pkt., 10c; lb., 20c; 10 lbs., \$1.50.

MELTING SUGAR-The kind that has sweet, broad pods, and are used the same way as snap or string beans. This is the most popular of the edible podded varieties. The pods are large, straight, very tender and finely flavored. Vines medium height. Pkt., 5c; oz., 10c; lb., 25c.

If you want an Incubator that will give perfect satisfaction, buy Chas. A. Cyphers' New Model. 


\section{PUIMPKINS}

CULTURE-Sow in grod soil in May, when the ground has become warm, in hills eight or ten feet apart each way, or in fields of corn about every fourth hill; plant at the same time with corn: always avoid planting near other rines, as they will hybridize.

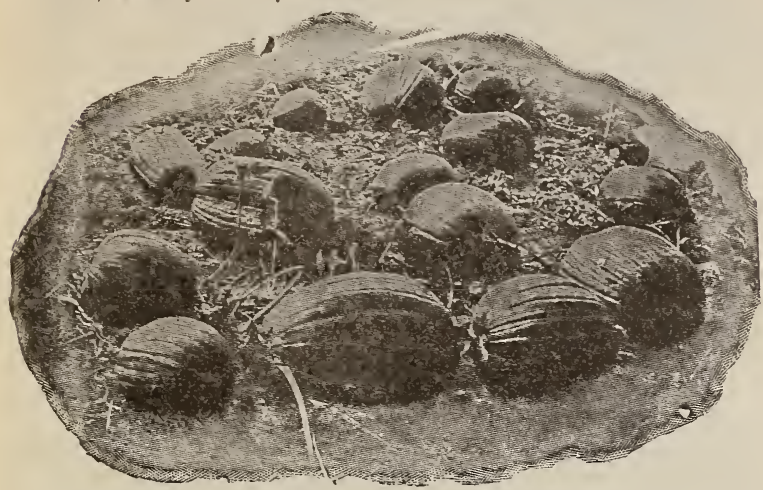

EARLY SUGAR-Fine-grained, sweet and prolific; small in size, but one of the best for pies. Pkt., 5c; oz., 10c; $1 / 4$ lb., 25c; 1b., 70c.

LARGE CHEESE - A popular variety in the South. Fruit flattened, the diameter being two or three times more than' the length. Skin mottled light green and yellow, changing to rich cream color as it matures; flesh tender and of excellent quality. Pkt., 5c; oz., 10c; $1 / 4$ lb., 20c; lb. 60c.

BIG TOM_This is one of the largest, most uniform growing and productire varieties known; it has been produced by an annual selection being made for a number of years from the old Golden Marrow by one of the largest canning establishments in Ohio, and who annually grow hundreds of acres especially for canning; they say that they can find no variety equal to it for this purpose. Per oz., 10c; $1 / 4 \mathrm{lb} ., 20 \mathrm{c} ; 1 \mathrm{~b} ., 50 \mathrm{c}$.

CONNECTICUT FIELD-A productive, large, orangecolored field pumpkin, usually grown for stock feeding, but. it makes good pies. Pkt., 5c; 0z., 10c; 1/4 lb., 20c; lb., $40 \mathrm{c}$.

MAMMOTH PRIZE-The largest pumpkin grown; has attained a weight of 225 pounds. If you wish to see just how large a pumpkin can grow, try the Mammoth Prize. The quality is excellent. Pkt., 5c; 0z., 15c; 1/4 Ib., 30c; Ib., \$1.00.

\section{PEPPER}

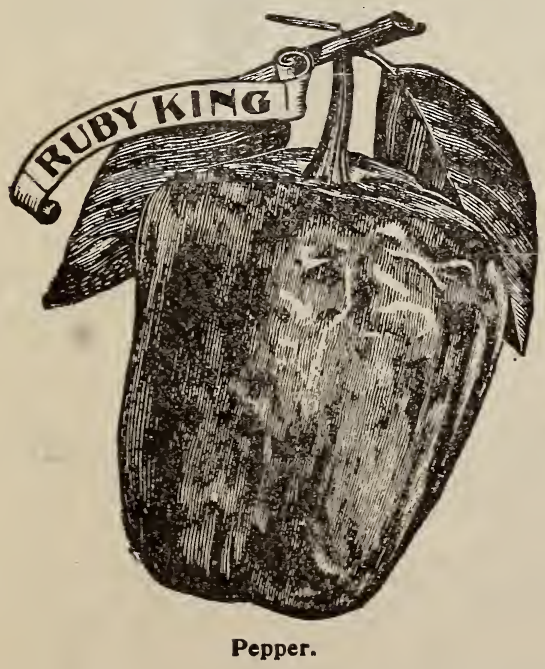

Sow the seeds early in hotbeds, or later, when the weather becomes warm, in open beds; when two or three inches high, transplant to a warm, mellow soil, in rows eighteen inches apart at one foot apart in the row. Guano and hen manure are excellent fertilizers, and will greatly increase the yield.

RUBY KING-An improved American sort, reaching the largest size, yet retaining the symmetrical shape of the smaller sorts. It is very bright colored, beautiful, sweet and mild flavored. Pkt., 5c; 0z., 30c; $1 / 4$ 1b., $75 \mathrm{c}$

LARGE BELL, OR BLUE NOSE-A large, mild, thickfleshed variety. One of the best for stuffed pickles. Pkt., 5c; 0z., 30c; 1/4 lb., 75c.

CHINESE GIANT PEPPER-Without doubt one of the rery best and largest Mango Peppers ever introduced. Of mammoth size, splenciid shape, beautiful, rich, glossy-red flesh and mild flavor. Pkt., 10c; 0z., 40c; 1/4 lb., \$1.00.

LONG RED CAYENNE-Brilliant coral-red pods, three or four inches long, and a prolific bearer; very pungent and used rery largely with pickles when green. Pkt., 5c; oz., 25c; $1 / 4$ lb., $75 c$.

RED CHILI-Small, bright red peppers, very hot and pungent, and generally sued for making '"Pepper Sauce.' Very prolific. Pkt., 5c; 0z., 25c; 1/4 lb., 75c.

\section{PARSLEY}

Very useful for flavoring soups, meats, and for garnishing. The green leaves are used for flavoring, or they may be dried crisp, rubbed to a powder, and kept in bottles until needed.

CHAMPION, MOSS CURLED-A compact growing, finely cut and much curled variety of bright green color. Pkt., 5c; 0z., 10c; 1/4 lb., 20c; 1b., 65c.

\section{PEANUTS}

The peanut thrives and produces best on a light, sandy fertile soil with a good clay subsoil. It possesses a long tap-root, which extends deep into the earth, drawing thence the nutriment which is beyond the reach of many of our cultivated crops. Per Ib., 35c.

\section{PARSNIPS}

CULTURE-Parsnips do the best in rich, deep soil, but will make good roots on any soil which is deep and mellow and moderately rich. As the seed is sometimes slow to ger minate it should be sown as early as possible. Cover one-half inch deep and press the soil firmly ove rthe seed. Give frequent cultivation and thin the plants six or eight to the foot. One ounce will sow 150 feet of drill; five pounds, one acre.

IMPROVED GUERNSEY (Improved Half-Long) - A greatly improved and wonderfully fine strain of Guernsey parsnip. The roots do not grow so long as the Hollow Crown, but are of greater diameter and more easily gathered. It is a rery heary cropper. The roots are grained and of most excellent quality. Pkt., 5c; 0z., 10c; $1 / 4$ lb., 20c; $1 / 2$ lb., 30c; 1b., 50c.

LONG SMOOTH, OR HOLLOW CROWN (Abbott's Improved Long Sugar, or Long White Dutch Parsnip -A great cropper; tender, sugary, and considered the best for general cultivation. Parsnips are improved by remaining exposed to the frost. Pyt., 5c; 0z., 10c; $1 / 41 \mathrm{~b} ., 20 \mathrm{2} ; 1 / 2 \mathrm{lb}$., 30c; 1b., 50c.

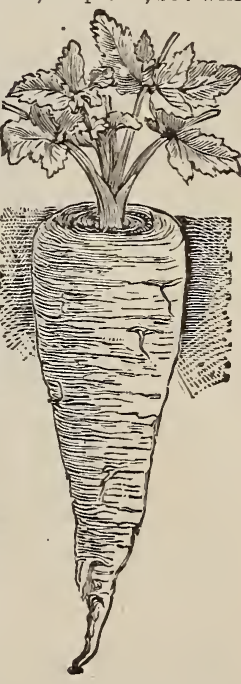

If you want an Incubator that will do good work, buy Chas. A. Cyphers New Model. Chas. Cyphers incubators are in most poultry plants. 


\section{RHUBARB OR PIEPLANT}

CULTURE - Rhubarb succeeds best in deep, rich, somewhat retentive soil. The richer its condition and the deeper it is stirred the better. Sow in drills an inch deep, and thin out the plants to six inche sapart. In the fall transplant the young plants into very highly manured and deeply stirred soil, setting them four to six feet apart each way, and give a dressing of coarse manure each spring. The stalks should not be plucked until the second year, and the plant never allowed to exhaust itself by running to seed.

VICTORIA, OR MAMMOTHVery large; finest cooking variety. Pkt., 5c; oz., 15c; 1/4 1b., 45c; lb. $\$ 1.50$.

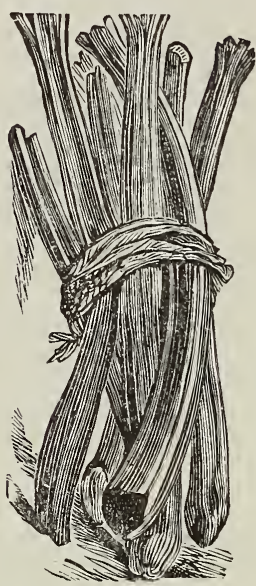

\section{RADISHES}

CULTURE-Radishes must make a rapid growth to be crisp and tender. For early use seed should be sown in the hotbed, in drills four or five inches apart and half an inch deep. For an early crop in the open ground select a sandy soil and a warm south border under the shelter of a fence or building, if possible. A load of fresh, sandy loam from the woods is better for the radish crop. As soon as the first leaves appear sprinkle with soot or ashes to save from the little turnip fly. One ounce will sow 150 feet of row.

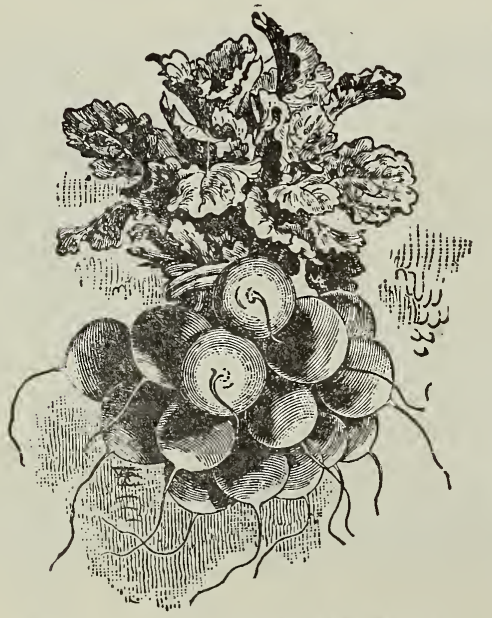

8CARLET TURNIP WHITE-TIPPED RADISH.

THE SECRET IN GROWING GOOD RADISHES consists chiefly in the observance on the part of the grower of three points. First, they should be grown on quick, light soil. Second, they should be given plenty of water; and last, but not by any means least, the right kind of seed should be sown. Radishes grow very quickly, and if not supplied with plenty of water are apt to be pithy.

EARLY SCARLET TURNIP, WHITE TIPPED-The favorite variety for outdoor cultivation; medium size; uniform shape; color bright scarlet sharply contrasted with white tip, which makes it most attractive. It grows quickly; flesh white, crisp and of the best quality. Pkt., 5c; 0z., 10c; 2 oz., 15c; $1 / 4$ lb., 20c; lb., 60c.
EARLY ROUND DEEP SCARLET-Similar in form to the Scarlet Turnip-Rooted, but much darker in color; flesh white, very crisp and tender; top small, well adapted for growing in frames. Pkt., 5c; oz., 10c; 2 oz., 15c; $1 / 4 \mathrm{lb}$, 20c; lb., 60c.

EARLY WHITE TURNIP-ROOTED-A little flatter than the Scarlet Turnip-Rooted, and pure white in color. It has a very small top, white, semi-transparent flesh, and is slightly later than the Scarlet Turnip but will stand more heat and remain longer in condition for use. Pkt., 5c; oz., 10c; 2 oz., 15c; $1 / 4$ lb., 20c; 1b., 60c.

FRENCH BREAKFAST, OR HALF LONG WHITE TIPPED-Medium size, of quick growth, crisp and tender; terminates more abruptly than the Half Long Scarlet, lower end and tap root white. Pkt., 5c; oz., 10c; 2 oz., 15c; $1 / 4$ lb., 20c; lb., 60c

EARLY LONG SCARLET-The leading variety either for the family or market arden. From six to eight inches long, standing nearly half above the ground; bright scarlet, smooth, crisp, tender and mild. Pkt., 5c; oz., 10c; 2 oz., $15 c ; 1 / 4$ lb., 20c; lb., 60c.

EARLY CRIMSON GIANT-The largest early Scarlet Turnip-Shaped Radish, A new early radish, double the size of any of the other early turnip-shaped type; but notwithstanding its immense size, does not get hollow and withstanding its immense size, does not get hollow and
pithy. The flesh is a sparkling white, solid, crisp and juicy, and of the mildest flavor. The shape of the bulbs vary from round to almost oval, but the bright, deep crimson color of the skin remains quite constant. Excellent for both forcing and the open ground. Pkt., 5c; oz., 10c; $1 / 4$ lb., 25c; 1b., 75c.

EARLY WHITE STUTTGART-Root large, often four inches in diameter, top-shaped. Skin white; flesh white and crisp, and not becoming strong or pithy until very late. Pkt., 5c; oz., 10c; 1/4 lb., 20c; lb., 60c.

NEW WHITE ICICLE-Enetirely distinct, long, slender, pure white. Very early; much the earliest and finest long white. It is ready for use full as early as Long Scarlet; short top, with less foliage, rendering it more desirable for forcing. In the open rgound the roots continue brittle, crisp and mild, until they are fully as large as those of the Long Brightest Scarlet. It is ready for use following the olive-shaped Earliest White, and destined to become a leading variety. In recent years strains of White Wood's Frame and Chartiers have been introduced and found of poor quality, but the Icicle is, perhaps. superior to the finest red ones. Roots pure, snowy white, four inches in length and half an inch in diameter; they retain their crispness and fresh, mild flavor until fully six inches long and an inch in diameter. Pkt., 5c; oz., 10c; 1/4 lb., 25c lb., $60 \mathrm{c}$.

IMPROVED CHARTIER-Roots long, tapering rather abruptly and attaining a very large size. Of rapid growth it is soon ready for the table, remaining crisp and tender until fully grown Color scarlet above, shading into until fully grown. Color, scarlet above, shading into
white at the tip. Flesh white and mild flavored. Pkt., 5c; oz., 10c; 2 oz., 15c; $1 / 4$ lb., 20c; 1b., $60 \mathrm{c}$.

LONG WHITE VIENNA, OR IADY FINGER-The best long white radish grown; pure white, long, tender and sweet; a favorite also for its beauty of form and rapid growth. Pkt., 5c; oz., 10c; 2 0z., 15c; 1/4 1b., 20c; lb., $60 \mathrm{c}$.

WHITE STRASBURG-One of the best of the large summer sort. It covers a long season, as it is good when quite small. The roots are long, very white, crisp and tender. Pkt., 5c; oz., 10c; 2 oz., 15c; 1/4 lb., 20c; 1b., 60c.

\section{Winter Varieties}

LONG BLACK SPANISH-Very hardy and good for winter use. If stored in sand will keep good all winter. The roots, which present a rusty, black appearance, are large, firm and not liable to become pithy. Pkt., 5c; oz., 10c; 2 oz., 15c; $1 / 4$ lb., 20c; $1 \mathrm{~b}$., $60 \mathrm{c}$.

MAIMMOTF CALIFORNIA, OR WHITE CHINA-Extensively grown by the Chinese, who introduced it into California. Very large and cylindrical, terminating abruptly with little tap root; mild and tender, and keeps well all winter. The skin and flesh are of a transparent white. Plst., 5c; oz., 10c; 2 oz., 15c; 1/4 lb., 20c; 1b., 65c. 


\section{SPINACH}

CULTURE - It is one of the most eas. ily managed of all vegetables, requiring but little culture. The main crop is sown in September and it is sometimes covered with straw
in exposed places during winter, which prevents it from being cut with frost.

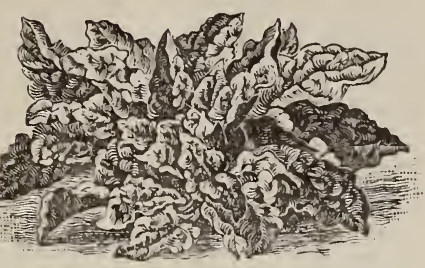

For summer use it mav be sown at intervals of two or three weeks from March to August. Spinach is best dereloped, most tender and succulent when grown in rich soil. One ounce to 100 feet of drill; 10 to 12 pounds to an acre.

BLOOMSDALE-A very early variety. Is hardy and may be planted for early spring use. Pkt., 5c; oz., 10c; $1 / 4$ lb., 15c; lb., 35c.

LONG STANDING-An improved variety, slow going to seed, and perhaps the best for general use. Pkt., 5c; oz., 10c; 1/4 lb., 15c; lb., 35c.

VICTORIA-Noted for its dark green leaves. It will outyield every other variety and at the same time stand longer without going to seed. Very desirable for the market or private garden. Oz., 10c; $1 / 4 \mathrm{lb}$., 15c; lb., 35c.

IMPROVED THICK LEAVED-A variety which grows very rapidly, forming a cluster of large, very thick, slightly savoyed leaves of fine color and quality when cooked. Best for market gardeners. Pkt., 5c; oz., 10c $1 / 4$ lb., 15c; lb., 40c.

\section{SALSIFY OR VEGETABLE OYSTER}

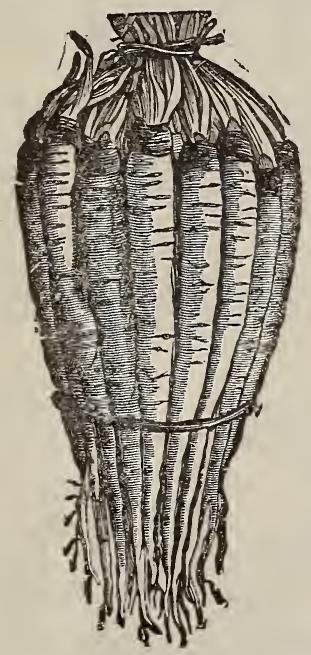

The long, white, tapering root of Salsify resembles small parsnip, and when cooked is a good substitute for oysters, having a very similar flavor.

CULTURE-It succeeds best in a light, well enriched soil, which should be stirred to a good depth. Coars and fresh manure should be avoided, as it will surel cause the roots to grow uneven and ill-shaped. Sow early and quite deep giving the general culture recommender for parsnips. The roots are perfectly hardy, and may remain out all winter, but should be dug early in the spring, as they deteriorate rapidly after growth commences. Store a quantity for winter use in a pit or in a cellar in damp earth or sand.

MAMMOTH SANDWICH ISLAND-This is in every way superior to the old sort, being larger, stronger growing and less liable to branch. Pkt., 5c; oz., 15c; 1/4 lb., 40c; lb., \$1.35.

\section{SQUASH}

\section{Summer Varieties}

CULTURE-The plants are very tender and sensitive to cold, and planting must be delayed until settled warm weather. The general principles of culture are the same as those given for cucumbers and melons, but squash is less particular as to soil. The summer varieties should be planted four to six feet apart each way, and the winter sorts eight to ten. Three plants are sufficient to a hill. In gathering the winter sorts care should be taken not to bruise or break the stem from the squash, as the slightest injury will increase the liability to decay.

MAMMOTH SUMMER CROOKNECK-An early, prolific kind, having a solid curred neck; the skin is yellow, thin, hard and very warty; flesh tender and of good quality. Twice as large as the ordinary Crookneck and several days earlier. Pkt., 5c; oz., 10c; 1/4 lb., 25c; 1b., 75c.

EARLY YELLOW MAMMOTH BUSH SCALLOP-An early, flat, scallop-shaped rariety; color yellow; flesh pale yellow and well Summer Crookneck. flavored; very productive. Pkt., 5c; 0z., 10c; 1/4 1b., 25c; lb., $75 \mathrm{c}$.

MAMMOTH WHITE BUSH SCALLOP-The best summer sort for the market; very productive and of good size. Pkt., 5c; 0z., 10c; 1/4 lb., 25c; 1b., 75c.

VEGETABLE MARROW-A favorite English variety, bearing freely oblong, dull yellow fruits 10 to 15 inches in length by 4 to 5 inches in diameter; flesh, before ripe, tender, marrowy and delicious. Oz., 10c; 1/4 1b., 30c; lb., $\$ 1.00$.

\section{Autumn and Winter Varieties}

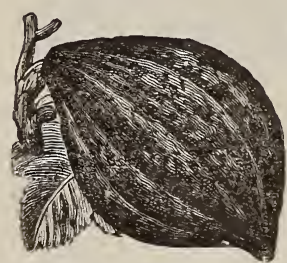

GOLDEN HUBBARD-This is a very distinct sort of the shape and general character of the Hubbard, but a little smaller; earlier to mature, and of a rich, orangered color, instead of the dark olive-green of the old Hubbard, while the flesh is a little deeper colored and fully as good quality. Pkt., 5c; oz., 15c; 1/4 lb., 35c; lb., \$1.00.

HUBBARD-The best seller and most popular variety on our list; rind dark green and very hard; flesh light orange, very dark, sweet and rich flavored; has no superior for winter use, as it keeps perfectly through the winter. Pkt., 5c; oz., 10c; 1/4 lb., 30c; lb., S5c.

BOSTON MARROW-A good keeper of excellent flavor; flesh orange colored and fine-grained. Pkt., 5c; oz., 10c; $1 / 4$ lb., 25c; lb., 80c.

MAMMOTH CHILI-The largest variety grown, having attained a weight of over $200 \mathrm{lbs}$.; round, flattened at the ends; rind deep orange; flesh deep yellow, thick and very nutritious; sometimes used for the table, but more desir able for stock feeding. Pkt., 5c; oz., 15c; $1 / 4 \mathrm{lb}$., 35c; lb., 85c.

\section{Planet Jr. Garden Tools meet all} the requirements for lightening the work in the garden. 


\section{TOIMATOES}

CULTURE-Sow the seed in March and April in the hotbed or in spots in a sunny exposure in the house. If it is desired to make very healthy, stocky plants they may be transplanted or repotted when about two or three inches high. When five or six inches high, if the ground has become warm, transplant to the open ground, on a rainy or cloudy day, if possible; if not, the young plants should be liberally watered and shaded from the hot sun. If it is desirable to have the fruit ripen as early as possible, in preference to a heavy crop, select rather light, poor ble, in preference to a heavy crop, select rather light, poor
soil, and a sunny location. Trimming off the laterals, training to a stake, and propagating by slips are believed by many to promote earliness. Set the plants four feet apart each way, upon mounds of earth, to allow the foliage to open and let the sun in amongst the fruit. A cheap trellis, made by driving three stakes around the plants and encircling them with three or four barrel hoops, makes a very nice support for training them on.

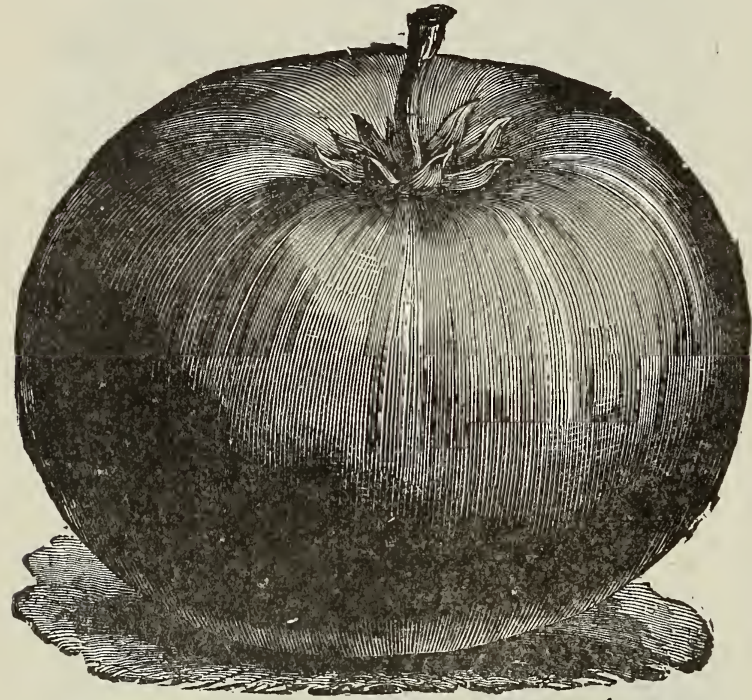

NEW TOMATO-CHALK'S EARLY JEWEL-The large, handsome fruits are very solid and deep through, being almost round or ball shaped; will measure nearly three and a half inchos across by nearly three inches in depth, from stem to blossom end. Color, brightest scarlet, ripening right up to the stem without any cracks or green core. The foliage is rather sparse and open, admitting the sunlight to the center of each plant so that all the fruits are light to the center of each plant, so that all the fruits are inclined to curl, as in most other first early varieties. Pkt., 5c; oz., 35c; 1/4 lb., \$1.00.

ATLANTIC PRIZE (Extra Early)-A distinctly early variety, of good size and smooth surface. Many of the objections to the usual early kinds, such as undersize, deep corrupgations and rough skin, are overcome in the Atlantic Prize. Pkt., 5c; oz., 25c; 1/4 lb., 70c.

PONDEROSA-The fruit ripens quite early and keeps on coming until very late; of immense size, solid, almost seedless, and of good sub-acid flavor. The fruits are somewhat scattered on the vine, and quite a percentage are too rough to please most growers. A very good tomato for home use. When ripe it is apt to remain somewhat green around the stem end, and it seems to ripen on the inside first; on this account it should be picked when it appears to be about three-fourths ripe. Oz., 25c; $1 / 4 \mathrm{lb}$., 75c; lb., \$2.00.

EARLY MICHIGAN-Having tested at one time or another nearly every variety offered by seedsmen, we confidently claim that there is no better sort than this for general market or family use. We speak emphatically because we know that for smoothness and regularity of shape, uniformity of size, color and freedom from rot or cracking this variety is unsurpassed. Its first fruits are quite early, but the vines continue to bear for a long time. Vines large, with large, dark green leaves, vigorous and wonderfully productive, being, under high culture, one of the heaviest croppers; fruit medium sized to large, and, like most other varieties, it produces larger fruit as the like most other varieties, it produces larger fruit as the a hard core; deep, rich red color, and of excellent flavor This kind is admirably adapted to canners' use. Oz., 20c $1 / 4$ lb., $75 \mathrm{c}$; lb., $\$ 2.25$.

SPARK'S EARLIANA-The earliest large and smooth tomato. The most perfect of all tomatoes. Of large, uniform size and beautiful red color. Quality almost beyond praise. A most vigorous grower and heavy bearer, conpraise. A most vigorous grower and heavy bearer, con-
tinuing until frost. Succeds everywhere and especially recommended for this section. The above claims may seem strong, but they have been abundantly proved by thousands of planters who have grown this grand tomato since its introduction three years ago. Spark's Earliana is as near seedless as any tomato, giving but 12 to 15 pounds of seed to the acre, while other varieties yield from 75 to 100 pounds to the acre. For this reason the genuine to 100 pounds to the acre. For this reason the genuine
seed can never be sold at a low price. Pkt., 5c; oz., 30c; $1 / 4$ lb., \$1.00; lb., \$3.00.

DWARF CHAMPION, OR TREE TOMATO-The plant is dwarf and compact; fruit medium size, rich, glossy red, smooth and solid; fine for private gardens. Pkt., 5c; oz. 25c; $/ 4$ lb., 75 c.

ESSEX EARLY FYBRID-Very similar to the Acme; fruit dark purple; always smooth and handsome; in qual ity it is classed with the best; will give satisfaction wherever the Acme does. Pkt., 5c; oz., 25c; 1/4 lb., 75c.

NEW STONE-Fine for main crop; very large; color lright scarlet; very smooth, ripening up to the stem with wut a crack; exceedingly solid and firm fleshed; an excellent shipper; quality the very best; not subject to rot. Superior for canning. Pkt., 5c; oz., 25c; $1 / 4 \mathrm{lb}$., $75 \mathrm{c}$.

PEACH-This is a distinct and very attractive tomato for preserving, eating from the hand or table. Fruit resembles a peach in shape, size and color, and is covered witl a delicate bloom, which makes the resemblance more striking; flesh tender and of good flavor. Pkt., 5c; oz., 30c.

GROUND CHERRY, OR HUSK-Plants of low, spreading orowth and immensely productive. The small yellow fruits are each enclosed in a husk or covering. When ripe the fruits are an inch in diameter, bright yellow and of very sweet flavor; highly esteemed for preserving or making pies. Pkt., 5c; oz., 30c.

\section{TURNIPS}

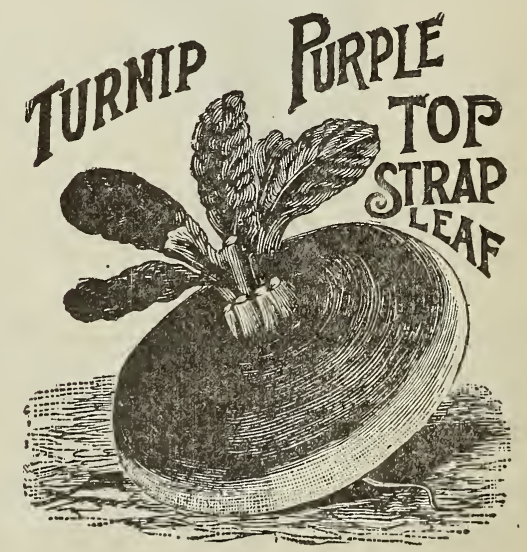

For feeding stock in fall and winter theer is nothing superior to turnips and rutabagas, as they are much liked by all kinds of stock and serve to keep them in good condition. We cannot too earnestly recommend farmers to increase their sowings largely, for we are sure the crop will prove remunerative. 


\section{[TURNIPS-Continued]}

CULTURE-For early, sow as soon as the ground can be worked, in drills 15 to 18 inches apart, and half an inch deep. Thin to six inches in the row. Turnips will grow on any soil that is moderately rich. An essential point is to make them grow quickly, otherwise they are apt to be tough and woody. They do best in light, loamy soil, that which has been manured for a previous crop is preferable to manuring with stable manure at time of sowing as in this case they are liable to be worm eaten, hence unsalable. Two pounds will plant an acre.

EARLY PURPLE TOP, STRAPPED LEAVED-One of the best and most universally grown; small, erect top, round, flat; purplish red above, white underneath; flesh firm, but very tender and sweet; it is soon ready for the table and keeps well. Pkt., 5c; oz., 10c; 1/4 1b., 20c; lb., 50c.

EARLY FLAT WHITE DUTCH, STRAPPED LEAVED -A leading white-fleshed variety, and one of the best, either for family, market garden or field crop; it is of medium size and produces a large crop. The flesh is firm but tender, and of a superior rich, buttery flavor. A good keeper. Pkt., 5c; 0z., 10c; 1/4 lb., 20c; 1b., 60c.

WHITE EGG-A quick growing, egg-shaped, perfectly smooth, pure white variety, with small top and rough leaves. It grows half out of the ground; the flesh is very sweet, firm and mild, never having the rank, strong taste of some of the early varieties. Pkt., 5c; oz., 10c; 2 oz., 15c; 1/4 lb., 20c; lb., 60c.

EXTRA EARLY MILAN-The earliest turnip; tops are very small, distinctly strap leaved, and growing ver erect and compact. Forms bulbs the earliest of any sort; the roots are very white. Pkt., 5c; oz., 10c; 1/4 1b., 25c lb., $75 \mathrm{c}$.

GOLDEN BALL, OR ORANGE JELLY-Medium size, globe-shaped bulbs; very early; flesh golden yellow, of fine texture and sweet. Pkt., 5c; 0z., 10c; 1/4 lb., 20c; lb., $60 \mathrm{c}$

POMERANIAN WHITE GLOBE (Strapped Leaved)This is a free growing, rough-leaved sort, useful for both table and stock. It is not quite so rapid in growth as the flat varieties, may be expected to come in as a succession in autumn and is admirable for table use in early winter. Pkt., 5c; oz., 10c; 1/4 lb., 20c; 1b., 60c.

YELLOW ABERDEEN-Round, medium size, light yellow; stained with purple on top; produces a large crop; is hardy and keeps well; flesh very firm, but tender and

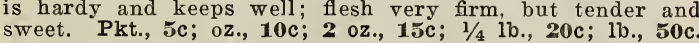

PURPLE-TOP WHITE GLOBE-A variety of the Purple-Top Flat Turnip, from which it originated. It is globular in form, of beautiful appearance and of most excellent quality. Equally desirable for table or stock. It keeps well and is a fine market sort. Pkt., 5c; 0z., 10c; 1/4 lb., 20c.; lb., 50c.

COWHORN-Sometimes called Long White. Is slightly crooked, pure white, except a little shade of green at the top. Grows half out of the ground and is of very rapid growth; is delicate and well flavored. Has proved itself one of the best stock turnips ever introduced in the West, and is an immense yielder. Pkt., 5c; 0z., 10c; 1/4 lb., 20c; Ib., 60c.

\section{Ruta Bagas or Swedes}

YELLOW SWEDE, OR RUTA BAGA-Shape oblong, dull reddish color above ground, but yellow underneath; is hardier than the common turnip and will keep till spring. Pkt., 5c; oz., 10c; 1/4 lb., 20c; ib., 50c.

SWEET RUSSIAN, OR WHITE -The only white-fleshed ruta baga in general cultivation; is hardy, easily grown, large and yields as heavy a crop as the best yellow kinds; flesh fine-grained and solid, but tender and well flavored; good for stock and desirable for the table Pkt, 5c: 0z 10c: oz., 15c; 1/4 1b., 20c; Ib., 60c.

\section{TOBACCO}

CONNECTICUT SEED LEAF - A largely cultivated sort in America. Large pkt., 5c. HAVANA-A genuine Cuban strain. Pkt., 5c.

\section{HERBS}

ANISE-Used for cordials, garnishing and flavoring. Plst., 5c; oz., 10c.

BALM-Leaves used for making pleasant beverages. Pkt., 5c; 0z., 25c.

BASII-Siveet; the leaves are used in flavoring soups, etc. Pkt., 5c; oz., 1.ic.

BORAGE-Leaves used for flavoring and the flowers furnish feed for bee pasturage: most easily grown in any waste place. Pkt., 5c; oz., 15c.

CARAWAY-Grown for seeds; used for flavoring. Pkt., 5c; 0z., 15c

CATNIP, OR CATMINT-Leaves and young shoots for seasoning. 'Pkt., 5c; oz., 35c.

DIII_-Seeds have an aromatic odor and pungent taste. Pkt., 5c; 0z., 10c; 1/4 1b., 25c.

FENNEI-Sweet; ornamental; when boiled, used in fish sauce. Pkt., 5c.

CORIANDER-Seeds used in the manufacture of liquors, in confectionery and culinary preparations. Pkt., 5c; oz., 10c; $1 / 4$ lb., 25 c.

HOREHOUND--For seasoning and cough remedy. Pkt., 5c; 0Z., 20c.

LAVENDER-An aromatic, medicinal herb. Pkt., 5c; oz., $20 \mathrm{c}$.

MARJORAM-Sweet; leaves and shoots for seasoning. Pkt., 5c; 0z., 15c.

SAGE-Most useful herb for seasoning. Pkt., 5c; oz. 20c.

SUMMER SAVORY-Used for flavoring soups. Pkt., 5c; oz., 10c.

THYME-Leaves and young shoots used for seasoning; a tea is made from leaves, a remedy for headache. Pkt. 5c; oz., 30c.

\section{TREE SEEDS}

Single Pound Prices are by Mail, Postpaid. $\$ 3.50$

PEACH PITS-For nursery stock. Lb., 20c; 100 Ibs.,

APPLE SEED-Oz., 10c; 1/4 lb., 30c; 1b., $75 \mathrm{c}$ $85 \mathrm{c}$.

PEAR SEED (Pyrus Communis)-The best imported for nursery stocks. Oz., 15c; $1 / 4 \mathrm{lb} ., 45 c$; lb., $\$ 1.50$.

QUINCE SEED-Oz., 20c; $1 / 4$ lb., 50c; lb., \$2.00.

BOX ELDER, OR ASH LEAF MAPLE (Acer Negundo) -Oz., 10c; 1/4 lb., 25c; 1b., 85c.

LOCUST, YELLOW OR BLACK-A tree of rapid growth. Sown in our Western states for timber. Oz., 10c; $1 / 4$ lb., 20c; lb., 50c.

LOCUST, HONEY-Oz., 10c; 1/4 lb., 20c; lb., 60c.

\section{By ordering your seeds early} you are sure of prompt delivery and good service. Don't wait until the rush is on-it may delay your garden making. 


\section{FLOWER SEEDS}

\section{CHOICE STANDARD VARIETIES}

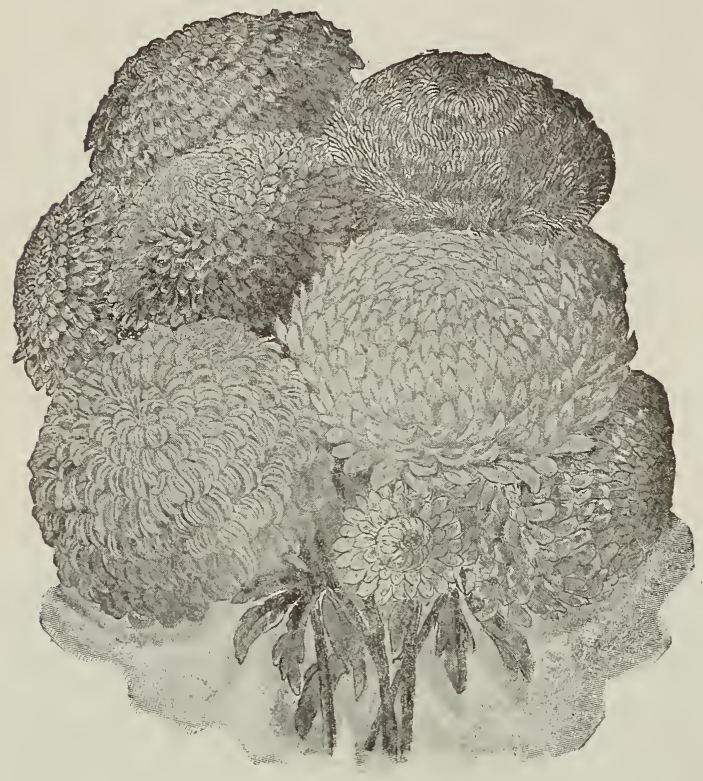

Asie:

CULTURE-Cultural directions are printed on the back of nearly all packets.

Flowers usually succeed best in a sandy loam, made rich with well rotted manure, which should be made fine and thoroughly mixed with the soil. A soil thus prepared will remain moist and loose, so that flower seeds, which are generally small and delicate, will germinate and grow with vigor.

A hotbed or cold frame is very convenient to start seeds in, as the temperature and moisture can be so regulated as to make their germination and growti more certain. Most seeds do well if sown in boxes in a sunny window in the house.

Plants are usually ready to be transplanted when they have made a growth of two inches.

Annuals bloom and ripen the first year and then they perish.

Many annuals in warm climates, or when taken in or protected during the winter, become perennial, with but short lives, however.

Biennials do not generally flower the first year, and are in perfection only one year.

Perennials continue to flower several years in succession.

Hardy Annuals, Biennials and Perennials can be sown in the open ground early in the spring, if desired, and Biennials and Perennials do not need any protection in the winter.

Half Hard Annuals, Biennials and Perennials should not be sown in open ground until settled warm weather, though they can be sown in the house, if desired, early, and afterward transplanted. The two latter need to be protected in the winter, or carried over until spring in cold frames or greenhouses.

HOHENZOLLERN ASTER-The finest type of the Giant Comet, or Ostrich Feather type of Asters. Much larger than the Giant Comet, the petals longer and more curled and twisted, and produced in greater abundance. Borne on long stems, which makes them cut flowers par excellence. We have them in separate colors-white, pink, blue, lav ender, rose and mixed. Price, per packet, 10c.
VICTORIA ASTERS-The flowers are very large and double; the plants bear ten to twenty flowers, pyramidal in form. eW have them in separate colors-rose, crimson, scarlet, blue, and pure white. Each, 10c a pkt. Many colors mixed, pkt., 10c.

SEMPLE'S BRANCHING ASTERS-The flowers are magnificent and very large, four inches across, are very double, of purest colors na dborne on olng stems. Height 18 inches to 2 feet. Many beautiful colors mixed. Pkt., $10 \mathrm{c}$.

GIANT COMET, OR OSTRICH PLUME-Are thrifty growers, 15 inches high, bearing immense long-stemmed flowers, composed of long, wavy petals, like Japanese Chrysanthemums. Giant Comet, mixed colors pkt., ac.

AGERATUM-A plant that blossoms continuously all summer in the garden and makes a pleasing contrast of color with more brilliant varieties. Pkt., sc.

ARCTOTIS-BLUE-EYED AFRICAN DAISY-A remarkably handsome new annual. It forms a branching bush 2 to 3 feet high. Its flowers are large and showy, being pure white on the upper surface, the reverse of netals being pale lilac blue. It is of the easiest culture and flowers from early summer until late fall. Pkt., 15c.

ALYSSUM-SWEET-A very pretty plant for beds, rases, baskets, edgings or rock work. Sweet scented and blooms profusely all summer. Pkt., 5c.

If you want some fine Asters, order Hohenzollern.

BALSAM-Unrivaled for the great variety of color and size of flower; includes all of the most desirable shades and colors; no finer mixture can be obtained. Pkts., 5c and 10c.

BACHELOR'S BUTTON-Well known annual of easy culture. Pkt., 5c.

BALLOON VINE-LOVE-IN-A-PUFF-A rapid-growing annual climber; succeeds best in light soil and warm situation; flowers white; seed vessels look like miniature balloons. Pkt. 5c.

BEGONIAS-Begonias are among the most beautiful of flowering plants, especially adapted to pot culture. Pkt., 5c. CANARY BIRI VINE-A beautiful climber; flowers a bright golden yellow, bearing a fanciful resemblance to birds wit hexpanded wings. Pkt., sc.

CANDYTUFT-Mixed, many fine shades. Pkt., 5c.

COLEUS-Probably the best known and most popular of ornamental foliage plants. Leaves all shades and colors. Tender perennial. Finest hybrid mixed. Pkt., 10c.

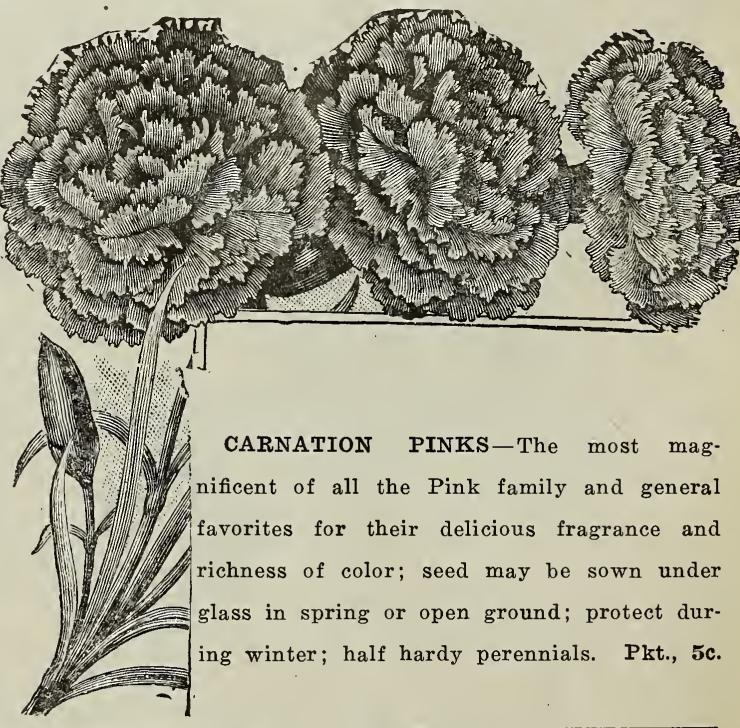




\section{[FLOWER SEEDS-Continued]}

CHRYSANTHEMUM-The Annual Chrysanthemums are rapidly coming to the front, both as greenhouse and gar den plants; they should not, however, be confounded with the Japanese perennial kinds that are being so widely introduced; the annuals have recently been greatly improved. Pkts., 5c and 10c.

COIUMBINE, OR AQUILEGIA-Commonly known as Honeysuckle. Produces handsome flowers of unique form and many attractive and bright colors. Hardy Perennial mixed. Best double or single varieties. Pkt., పc.

CELOSIA-COXCOMB-Free blooming annuals, growing best in light soil not too rich. They make splendid border plants and are attractive for pots. Mixed. Pkt., 10c.

COBAEA SCANDENS-One of the handsomest and most rapid growing of the annual climbers. It climbs thirt. feet in a season. The flowers are bell shape and of a purplish lilac color. Very prolific and perfectly hardy The vine is always clean of insects. Mixed. Pkt., 10c.

CANTERBURY BELI,S-Very ornamental garden plants of the easiest culture; hardy biennial, two and a half feet high, producing large, nodding and charming bell-shaped flowers of many exquisite shades. Pkt., 5c.

CYPRESS VINE, OR IPOMOEA QUAMOCLIT-A climber of rapid growth, having handsome, fernlike foliage and a profusion of bright, attractive flowers. Mixed. Pkt., 5c.

CASTOR OIL BEAN-Ornamental plants of stately growth and picturesque foliage with brilliant colored fruit, producing a sub-tropical effect; fine for lawns, massing or producing a sub-tropical effect;
center plants for beds. Pkt., 5c.

\section{Cosmos}

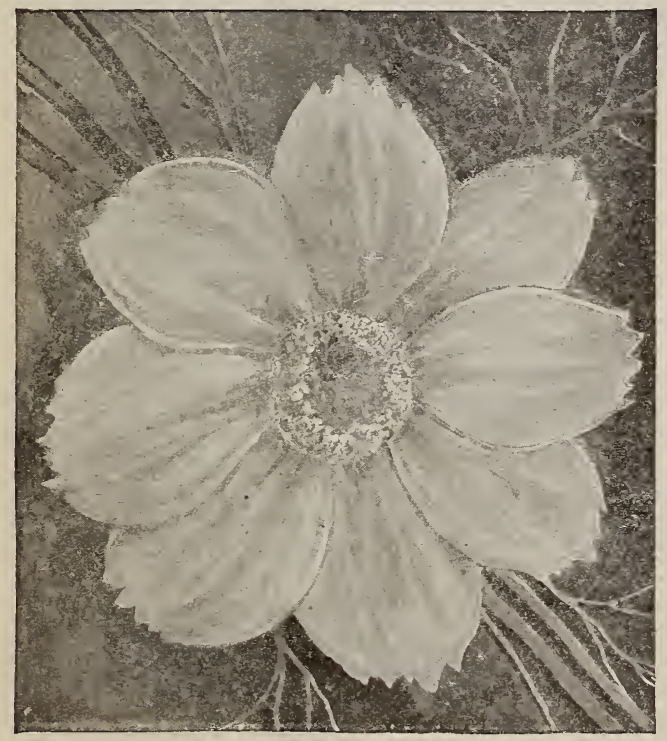

Cosmos

COSMOS-A strong grower, having elegant foliage, and for tall blooming has no superior. Seed sown in March or April and transplanted to open ground will produce plants three to fire feet high by September, which thereafter, until November, will yield hundreds of blossoms three inches across; various shades. Pkt., 5c.

DAHLIA-A well known and popular late summer and autumn flowering plant. Is grown from seed or propagated from bulbous roots. The seed mar be planted early in the hotbed and the plants set out in ger from frost is over. By sowing the seed early the plants may be made to bloom the first year. Dahlia Single Perfection, mixed, pkt., 10c. Double Cactus Flower. mixed, pkt., 10c.
DAISIES (Bcllis Perennis)-Very popular and easily grown flower; may be sown in the open ground early in May. Pkt., 10c.

SHASTA DAISY - A most remarkable new flower, orig. inated by Luther Burbank, of California; bears flowers of the snowiest white, with vellow centers; blooms the first season and should be sown in boxes early and transplanted. Pkt., 15c.

DIANTHUS (Chinese Pink) -Mixed; many distinct and beautifully marked varieties. Pkt., 5c.

ESCHSCHOLTZIA (Califormia Poppy) - The tSate Flower of California; an annual of rich, rare tints of yellow and orange. About a foot in height, beautiful foliage and large, poppy-like flowers. Pkt., כc.

FOUR し'CLOCK (Mirabilis) - Is also called Marvey of Peru. A handsome, free-flowering, sweet-scented plant. They open their blossoms about four o'clock in the afternoon, hence their name. Hardy annuals. Choice mixed varieties. Pkt., ฮ̄c.

FORGET-ME-NOT (Myosotis) - A modest little flower, to friendship erer dear. (See also Flowering Plants.) A pretty trailer with blue flowers. Pkt. 5c.

GERANIUM-Comparatively few are aware that Geraniums may be grown easily from seed and flower the first season if sown early. This is the best way to secure Geraniums, as they will frequently reward the cultivator with charming new varieties. In fact, propagation by seed is the only way to obtain new varieties. Pkt., 10c.

GLOXINIA - The Gloxinia is one of the most beautiful flowers, very few possessing the depth of color peculiar to this superb genus. Pkt., 25c.

GODETIA - An attractive, hardy annual deserving more extensive cultivation. The plants bloom profusely and bear showy flowers of rich and varied colors, one and one-half inches. All colors, mixed. Pkt., 5c.

GOURDS, ORNAMENTAL-Rapid growing, interesting annual climbers with handsome foliage and singular shaped fruit. Mixed varieties. Pkt., 10c; oz., 20c.

GYPSOPHILA, OR BABY'S BREATH-A pretty, freeflowering plant. Fine for bouquets. Pkt., 5c.

HELIOTROPE-One of the finest for cutting, as the delicious fragrance of all the varieties is very durable. For the same reason they make excellent house plants. Sow early in the spring. Choice mixed. Pkt., 10c.

HOLIYHOCKS-These fine, old-fashioned perennials are most striking when planted in groups or long rows; their variety of color is wonderful. Then plants are once obtained they last for several seasons. Mixed colors. Plt., taine.

LOBEIIA - A very valuable and beautiful dwarf-growi-g plant, delicate drooping habit and profusion of charming little blue and white flowers. Choicest mixed. Pkt., 10c.

IARKSPUR-One of the most showy and useful plants. making useful border flowers. Pkt., 5c.

MOON FLOWER, OR IPOMEA, MIXICANA GRANDIFIORA-Rapid growing climber, belonging to the Morning Glory family. The flowers are large, waxy white and very showy. Pkt., 10c.

MORNING GLORY - New Japanese; the surpassing charm in this grand variety lies in the entrancing beauty and gigantic size of the flowers. Pkt., 5c.

MORNING GLORY-Tall, fine mixed; a great variety of colors of the popular old-fashioned sorts. Pkt., 5c. MIMULUS-Moschatus, or Musk Plant. Cultivated for its rich musk odor. Should have a rich soil and ample moist ure. Hardy and perennial. Pkt., sc.

MARIGOID- Well known, extremely showy garden plant with handsome double vellow and brown flowers of varied shades; sueceeds in good garden soil. Annual. Pkt., 5c.

MOUNTAIN ROSE-One of the most beautiful as well as one of the rarest hardy climbers. It is absolutely hardy, and, once planted, is practically everlasting. Produces immense clusters of deen carmine flowers with deep green folage, freely furnished with long tendrils that attach themselves firmly to stone, brick or wood walls. Pkt., 10c.

Use REX IIME AND SUIPHUR around the roots of cabbage and cauliflower to Kill Wire Worms and Cut Worms. 


\section{[FLOWER SEEDS-Continued]}

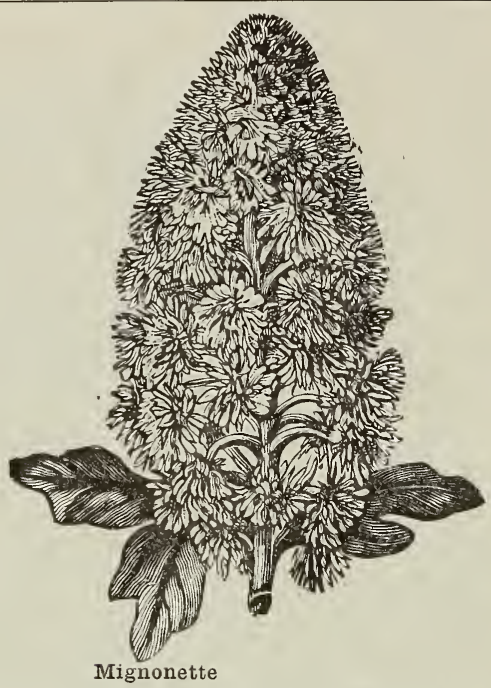

MIGNONETTE, RESEDA-A well-known fragrant favorite, and no garden is complete without a bed of Mignonette. Sowings are made in April and again in July, will keep up a succession from early summer until îrost. Pkt., 5c; oz., 25c

NASTURTIUM, TALL OR CLIMBING-A very wellknown ornamental, profuse flowering plant, adapted for rock work. The seeds, if picked young, are an excellent substitute for capers. Pkt., 50c; oz., 10c.

NASTURTIUM, TOM THUMB OR DWARF-When planted in beds or masses the brilliant effect of these splendid flowers is scarcely surpassed by any of our finest bedding plants. Pkt., 5c; oz., 10c.

NIGELIA-LOVE IN A MIST, OR DEVII IN THE BUSH-DAMASCENA-A compact, free-flowering plant, with finely cut foliage, curious-looking flowers and seed pods; of easy culture, growing in any garden soil; hardy annuals; blue and white mixed. One foot. Pkt., 5c.

NICOTIANA-AFFINIS- (Tuberose-Flowered Tobacco) -Delightfully sweet-scented, pure white tubular flowers, blooming continually; annuals; two to three feet high. Pkt., 5c.

PORTULACA-Brilliant, dwarf annuals, only six inches high, luxuriating in warm situations and blooming profusely from early summer to autumn. For low beds and masses of color, from spring until frost, they are indispensable; colors range through innumerable shades of red, yellow, pink striped, white, etc. Mixer. Pkt., 5c.

PRIMROSE-CHINESE-The culture of these lovely flowers is much easier than most people think. Our mixture includes not only all the choicest colors of the singleflowering Primulas in all their dainty shades, but it comprises also seed saved from hybridized flowers, and will produce a number of double flowers and the new blue Primula. Pkt., 10c.

PETUNIA-For outdoor decoration or house culture few plants are equal to this class. They commence to bloom early and continue to flower through the summer. Give them a rich soil and sunny place. Choice mixed. Pkt., 5c.

\section{Poppy, or Papaper}

The Poppy is well known and really a magnificent flower which is borne separately on tall stalks. Poppies are very showy and come in many bright and charming colors. They are hardy annuals, and may be sown where they are to remain, as soon as the ground can be prepared.

SHIRLEY - The range of color, extending from white through the delicate shades of pink, rose and carmine to deepest crimson; fine for cutting. The best single mixed Plst., 10c; $1 / 4$ oz., $25 \mathrm{c}$.
DOUBLE CARNATION FLOWERED-Fringed; colors are dazzling. Mixed. Pkt., 5c; oz., 25 c.

ICELAND, OR NUDICAULE-These are of a very graceful, neat habit, with bright green, fern-like foliage, formed in tufts, from which issue slended stalks about twelve inches in height, bearing yellow, white or orange-scarlet flowers in endless profusion and most useful for cutting; hardy perennial. (See cut.) Mixed colors. Pkt., 10c; 1/4 0z., 40c.

PHLOX DRUMMONDII_Of all summer-flowering annuals the varieties of Phlox Drummondii are unquestionably one of the most brilliant and satisfactory. Seed may be sown in the open ground any time after danger from frost is past, and in a few weeks the beds or borders are aglow with their brilliant coloring and remain so until cut down by frost. For early flowering they should be started indoors or in a hotbed. Mixed colors. Pkt., 5c.

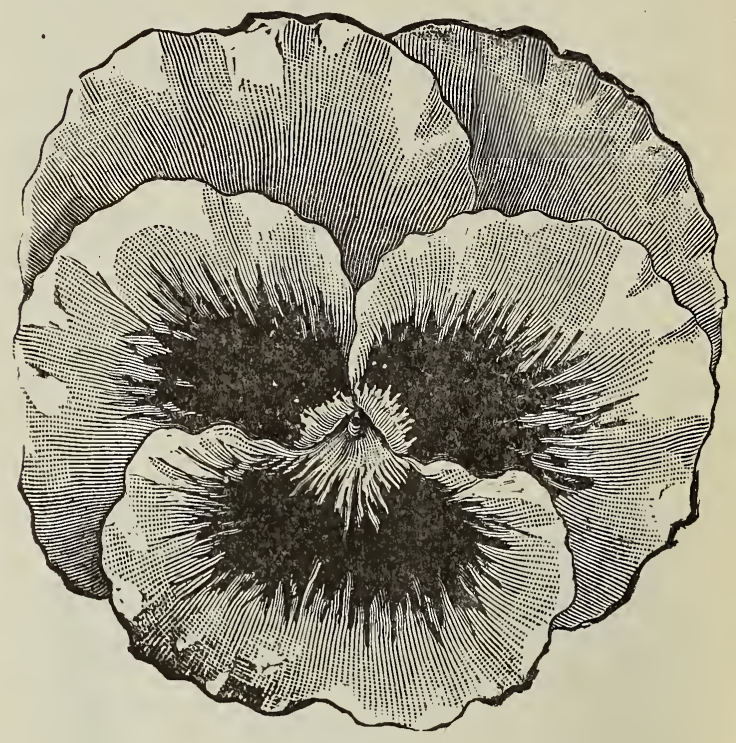

Pansies.

PANSY (Viola Tricolor) - A half hardy perennial, growing four to six inches high and probably the best known and among the most popular flowers in cultivation. It thrives best in a moist, shady location, and in rich, loamy soil. Seed should be sown in the autumn for early spring blossoms, or can be sown early in the year for good flowers later in the spring.

FANCY GIANT, MIXED-A splendid mixture of various shades and markings. The blossoms are perfectly round and are blotched at the base of three to five of the petals. Pkt., 10c.

FINE MIXED-A fine assortment of colors. Pkt., 5c.

THUNBERGIA-Rapid growing annual climbers; splendid for trailing over trellises, fences, etc.; beautiful flowers borne in profusion; buff, white, orange, etc.; four to six feet high. Mixed colors. Pkt., 5c.

VERBENA-Very few annuals will make such a gorgeous display during the summer months, or furnish more flowers for cutting, than the Verbenas. Start seed in the house or under glass early in the spring and transplant after three or four inches of growth. They flower in July and continue strong and healthy until destroyed by frost. Fine mixed. Pkt., 5c.

VIOLETS-Viola Odorata is the well known English Violet, a free-flowering, hardy perennial. Easily grown from seed, though somewhat slow in germinating; succeds best in partially shaded moist places. Choice mixed. Pkt., 10c.

WALI FLOWER (Cheiranthus cheri)-Produces spikes of beautiful, exceedingly fragrant flowers. Half hardy perennial. Mixed. Single, large flowering. Pkt., 5c. 


\section{[FLOWER SEEDS-Continued]}

WILD CUCUMBER-A well-known vine, common in many sections, and the quickest climber known for covering verandas, old trees and houses, trellises, etc., never suffering from the heat, but retaining its fresh lively green color: never infested wit hinsects and very profuse in bloom. It will sow itself and come up in the same place. Plkt., 5c; oz., 20c.

ZINNIAS (Youth and old Age)-Is one of the most brilliant and showy annuals, and has long been a general favorite. The seed can be sown early in the hotbed and transplanted, or sown later in the open ground. They come in flower early in the summer and keep on blooming until hard frost. Choice mixed. Pkt., 5c.

SCARLET RUNNER-Ornamental and useful; the vine is graceful; flowers are of a brilliant scarlet and the beans are of an excellent quality, either when shelled or in a dry state. Pkt., 5c; 1b., 25c.

SALPIGLOSSIS-The quaint, funnel-shaped flowers somewhat resemble those of the petunia; beautiful range of colors. Pkt., 5c

SNAPDRAGON, OR ANTIRRHINUM-One of the most useful and showy of border plants. Of almost every color, and striped as beautifully as carnations. They have recently been much improved and are now really magnificent. Hardy perennial. Finest mixed. Pkt., sc.

IARGE FIOWERING, 10-WEEK STOCK-This is the leading class for bedding out or summer-blooming. All varieties, mixed. Pkt., 5c; oz., 20c.

SWEET WILIIAM-A well-known, attractive, freeflowering, hardy perennial, producing a splendid effect in beds and borders with rich and varied flowers. The demand for seperate colors has induced us this season to ofrer several of the best and most distinct flowering sorts.

Mixed. Pkt., 5c; 0z., 20c.

\section{SWEET PEAS}

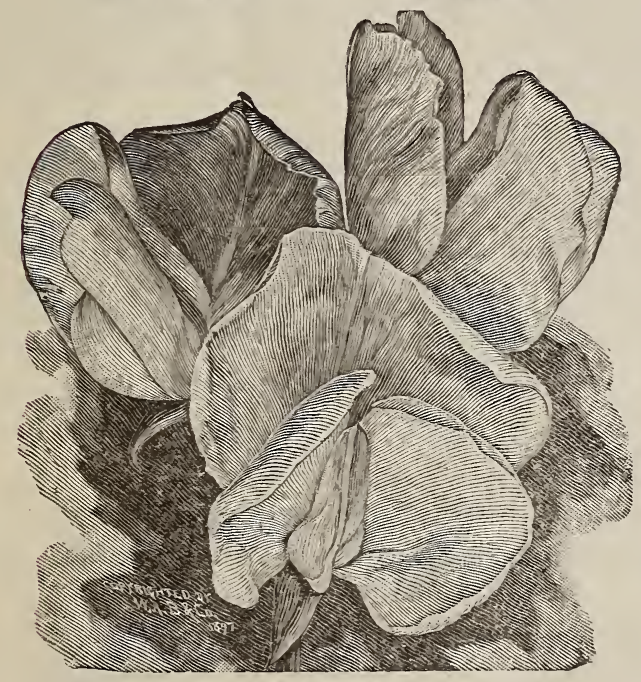

CULTURE-Early in the spring make a trench about four inches deep in rich, mellow soil, so arranged that no water can stand in it, and plant the seed in the bottom, covering no more than two inches. Sweet Peas, particucovering no more than two inches. Sweet Peas, particu-
larly the white seeded sorts, are often a little difficult to start. If the soil is too dry they will remain a long time without germinating; if it is too wet and cold they will not sprout at all. In soils at all heavy or composed largely of clay, put about one inch of sand in the bottom of the trench and sow the seed on this, covering with more sand. Cover the row with a board to shed the rain and protect the soil from the hot sun, but remove this as soon as the young plants appear. When the plants are about as the young, plants appear. When the plants are about some support for the vines to run upon. The blooms should be picked before they form pods or the plants will soon stop flowering.

\section{New Large Flowering Sweet Peas}

VIOLET-So much has been written and said about this grand new blue that it must be familiar to all lovers of the Sweet Pea. The color is almost a true violet-blue self; the standard is only slightly hooded; flower of grand size and substance. A very vigorous grower. Pkt., 10c; 0z., 20c; $1 / 4$ lb., 45. c; lb., \$1.00.

PHENOMENAL-Thite, shaded and edged, with lilac. Very large, the lower blossom on the stem is usually double. The petals are delisate and wavy. A grand orchid-flowering variety. Pkt., 10c; 0z., 20c; $1 / 4$ lb., $45 c$ lb., $\$ 1.00$.

APPLE BLOSSOM-Large, beautifully hooded, shaded and edged with soft rose on silvery white. Pkt., 15c; oz. 20c; $1 / 4$ lb., 45c; lb., \$1.00.

HENRY ECKFORD-An intense bright shining orange self color, quite unique and absolutely distinct. Pkt., 10c; oz., 20c; 1/4 lb., 45c; lb., \$1.00.

\section{Cream of the Sweet Peas}

ALL VARIETIES-Postpaid. Pkt., 5c; 0z., 10c; 1/4 1b., 25c; $1 \mathrm{~b} ., 60 \mathrm{c}$.

\section{Light Pink}

STEILA MORSE-Flowers of a peculiar warm salmonpink. A combination rellow and pink which is distinct and very attractive.

ELIZA ECKFORD-Primrose turning to white.

KATHERINE TRACY-The color is a soft but brilliant pink in wings and standard. Plants vigorous and give a profusion of flowers, which continue large and fine until the end of the season.

\section{Pink and Red Stripes}

AURORA-Very large and of fine form. The standard and wings are striped and flaked with delicate orangesalmon-pink over white.

\section{Lavender and Blue}

COUNTESS OF RADNOR-Self-colored in a very distinct and beautiful shade of lavender. blue.

EMILY ECKFORD-Heliotrope-blue, wings lavender

NAVY BLUE-A true blue.

LADY GRISEL HAMILTON-Most attractive light lavender shading; flowers of large size.

\section{Purple and IVaroon}

BIACK NIGHT-One of the darkest varieties. Oz., 10c; $1 / 4$ lb., 20c; 1 b., $60 \mathrm{c}$.

SHAHZADA-This has a very rich dark maroon standard and deep violet wings. One of the finest dark sorts.

GRAY FRIAR-Flakes and speckled blue and mauve on white.

COUNTESS CADOGAN-Large flowers. The color effect is that of a bright blue.

\section{Orange and Salmon}

IADY MARY CURRIE-Large, salmon-pink and shaded with carmine.

GORGEOUS-Brilliant orange-salmon, wings of orangemadder.

QUEEN VICTORIA-Light primrose of hooded form, showing a pink tint in the bud; clear, soft primrose when matured.

\section{Red Standards, White Wings}

BLANCHE FERRY-Bright pink standard and nearly white wings. 


\section{[SWEET PEAS-Continaed]}

\section{Shades of Red}

LORD KENYON-Magenta-rose, wings veined with a deeper shade.

HER MAJESTY-A delicate rose-pink color.

MAJESTIC-Fiery carmine, wings rose-madder.

SALOPIAN-One of the most brilliant sorts yet introduced. The ffowers are of faultless form, large and a rich, brilliant cardinal red.

FIREFLY-Bright and intense crimson-scarlet.

KING EDWARD VII-A lovely, intense crimson. A truly giant-flowered variety. The finest crimson to date. Strong stems and growth.

\section{White}

BLANCHE BURPEE-A splendid pure white variety. While not so profuse a bloomer or as hardy a plant as the Emily Henderson the flowers are fine.

EMILY HENDERSON-A bold, well formed, clear white flower. Wings broad and well expanded. An early and wonderfully free and persistent bloomer.

\section{Mixed Sweet Peas}

BEST LARGE FLOWERING MIXTURE-This is the best mixture that can be made fro mexisting varieties. The colors are well proportioned and the amount of each is determined by a well-studied and carefully arranged formula, which has been tried and corrected for mony years. mula, which has been tried and corrected for mony
All the newer and best varieties are in this mixture.

\section{VEGETABLE PLANTS AND ROOTS}

\section{Prices Given Below are by Express or Freight Only. No Plants Sent C. O. D.}

We grow large quantities of vegetable plants, and canPRICES FOR TOMATO PLANTSsupply all of the varieties listed below, in their proper season, in most any quantity. We have made arrangements this year so we can supply all vegetable plants in two grades-plants direct from the seed beds and those that have been transplanted into shallow boxes.

TRANSPLANTED PLANTS are much stronger and better rooted and are well worth the price, especially in the early part of the season. We can supply most of the leading sorts.

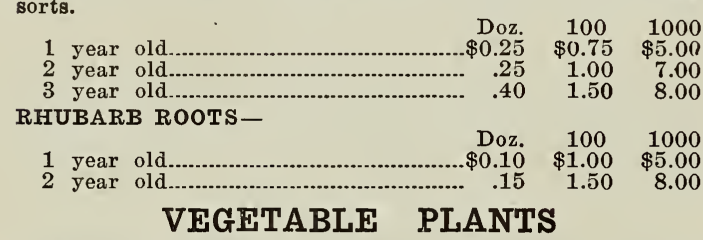

\section{CABBAGE PLANTS-}

Doz. $\quad 100 \quad 1000$

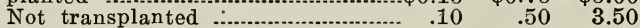

$\begin{array}{cccc}\text { Danish Ball Head and other varie- } & & & \\ \text { ties red and savoy....................................... } & .10 & .40 & 2.50\end{array}$

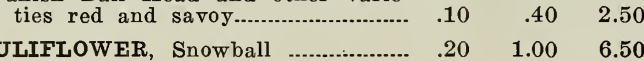

$\begin{array}{llllll}\text { CAULIFLOWER, Snowball } & \text {................... } & .20 & 1.00 & 6.50 \\ \text { CELERY - } & . & & & & \end{array}$

Early White Plume, transplanted...... $\quad .20 \quad 1.00 \quad 6.00$

Not transplanted ...............................

Late kinds, not transplanted................

PARSLEY

SAGE, culinary herb.............................

PEPPERS, mild for mangoes and the hot kinds ...

EGG PLANTS

$.15 \quad .75$

.50

$.20 \quad 1.00$

$.20 \quad 1.00$

SWEET POTATO PLANTS................... $\quad .25 \quad 1.00$

TOBACCO

$.25 \quad 1.00$

CHIVES (Schnittlauch) per clump $25 \mathrm{c}$

HOP ROOTS

MINT ROOTS

HORSE RADISH SETS

\section{TOIMATO PLANTS}

We grow immense quantities of Tomato Plants, and those listed are the very best varieties for the Northwest. We have stock from March until August.

EARLY RUBY - In this we have an old standard that will give a crop when all others fail.

SPARK'S EARLIANA-The tomato that has more favorable comment, perhaps, than any other ever introduced. We highly recommend this variety, especially under irrigation.

DWARF CHAMPION-The great toamto for the home. Showy and attractive in appearance and responds to high culture. Deep, rich red color; superior table quality; unsurpassed.

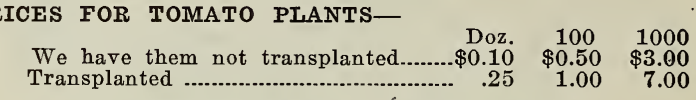

\section{STRAWBERRY PLANTS}

Our customers say that our strawberry plants are the very best they have ever seen. Our plants are grown in very highly fertilized soil and we send out plants only from parent plants that are not more than one year old. The varieties we list are the very best.

MAGOON-Mid-season. This is an exceedingly high quality and beautiful berry. If you want something fancy try this berry.

HOOD RIVER, S-Mid-season, dark red, a splendid canning berry.

GLEN MARY, S-Mid-season to late, a good variety.

WM. BELT, S-Mid-season, standard, reliable sort.

GANDY, S-The large, late kind, handsome and productive.

PRICE OF STRAWBERRY PLANTS-DOz., 25c; 100, $\$ 1.00 ; 1000, \$ 6.00$.

We also handle Pansy, Aster and other Flower Plants. Rose, Early Ohio, Sunlight, Burbanksemfwyemfwycmfwypp

\section{SEED POTATOES}

We aim to carry all of the standard varieties Early Rose, Early Ohio, Sunlight, Burbanks, Carmens, etc.

Write for prices, stating quantity wanted.

\section{HERE ARE A FEW HINTS TO THE BEGINNER HOW} TO MAKE A HOTBED.

First, pile up some fresh horse manure, not taking too much bedding, and wet it thoroughly. In two or three days it must be turned over, throwing the outside manure in the center of the new pile and breaking up all the lumps. It will have to be turned once more before it is ready to put in the bed. Dig a trench five feet eight inches wide by 24 or 30 inches deep and any length desired. In the trench put the manure that has already been heated, putting a put the manure that has already been heated, putting a
layer of six inches at one time, and then wetting every time till you have two feet of manure, and then top it with six inches of well-pulverized soil. Then make a frame with one or two-inch boards, 12 inches wide for the back, and six inches for the front, and cover with a sash three by six feet. If you cannot get a glass sash, a wooden frame of same dimensions, covered with hotbed cloth, will be almost as good. After the soil is on the manure, the bed will commence. to heat up, but will be too hot to sow seeds, and it mence to heat up, but will be too hot to sow seeds, and it will take about a week before it is safe to sow it. Care
should be taken to water the hotbed enough, and ventilate it whenever the weather permits, or the plants will be liable to be damped off and die. Shutters and mats are used for covering the sash at night to prevent too rapid radiation of the heat. Manure stacked against the frame will help to keep the frost out. 


\section{CLOVER AND GRASS SEEDS}

As Clover and Grass Seeds prices are continually changing we cannot print prices good for any length of time. When ready to buy, write us for special prices, stating qunatity wanted.

\section{Alfalfa, Clover of Lucerne}

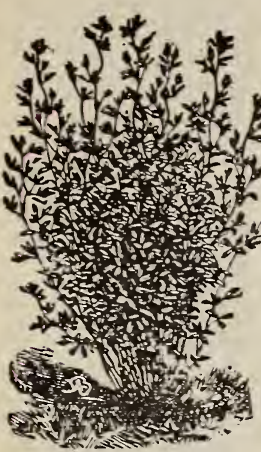

ALFAEFA. and pat cla sull.

The most valuable forage plant; is particularly adapted for Testern climate and soil. It requires a deep, mellow soil; newly broken sod does not do so well. It thrires best in a sandy loam, the richer the better, while it has not proved a success on heavy, every blade of falfa is as fresh and green as in the spring, as its roots go down from 10 to 20 feet to the moisture of the ground. Although a prodigious vielder, it does not exhaust the soil, but rather improves the ground by the decay of its lon roots, and converts it into rich ground, full of vegetable matter. The seed may be grown early in the spring, as soon as the frost is out of the ground, in order to catch the spring rains, as it needs moisture to germinate. In localities where irrigation is used it can be sown successfully at any time during the summer months. Most of our successful Alfalfa growers prefer sowing the seed broadcast, while others are more in pror of driling it in. It is ast, while others are more in first year, but will, when once started, produce a profitable first year, but will, when once started, produce a profitable
crop; under favorable circumstances three and even four crops are cut yearly, aggregating five to seven tons to the acre. Never sow less than 15 pounds of good, celan seed to the acre, as thin sewing produces thick and coarse stalks not relished by stock. If intended to raise Alfalfa for the seed, 12 to 15 pounds is plenty to sow on an acre. It is worthy of trial in any locality where it has not already been tested. Per lb., postpaid, 35c; 100 lbs., write for prices.

\section{Tukestan Alfalfa}

This new Alfalfa, introduced from Turkestan, has been experimented with more or less for the past few years. In some places it has proved a great success. In general appearance it is very much like our regular Alfalfa. It is claimed that it will produce a luxuriant growth in the driest and hottest sections without irrigation. It is perfectly hardy and will stand extreme cold in winter without harm. It yields a very heavy and rich crop of hay and makes permanent pasture. We have secured a good stock of the pure, genuine seed, which we offer at the following of the pure, genuine seed, which we offer at the followin
prices: Per lb., postpaid, 35c; 100 lbs., write for prices.

\section{Dry Land Alfalfa}

For high, dry, hot land. We are now able to offer in quantity this new Dry Land Alfalfa, which will porduce large, profitable crops of hay and excellent pasture on the high, dry lands of Eastern Oregon, Washington, Idaho and Utah. This is especially recommended for the hills and plateaux which are above irrigation ditches or in sections where irrigation is impossible. "The new "Dry Land" Alfalfa is what might be called "a new strain, acclimated to dry land." "Price per lb., postpaid, 35c; 100 lbs., write dry land.

\section{Mammoth or Sapling Clover}

Being a rank grower makes it most valuable for fetrilizing purposes. Foliage, flower and stem much darker than common Red Clover; ripens later than the latter, about the time Timothy, Red Top and other grasses ripen, making thereby a much better quality of hay, when mixed with
them. Sow 12 to 15 lbs, to the acre. Per lb. 30c; 100 lbs., write for prices.

\section{Alsike, or Swedish Clover (Trifolium Hybridum)}

A perfectly hardy variety which is rapidly growing in popular favor. It yields large crops of excellent hay, and

under farorable conditions may be cut several times dur ing the season. It is also valuable for bees. It is well calculated to resist both drought and excessive moisture. The hay of this variety is greatly preferred by some to that of Red Clover, for the reason that it is generally finer brighter and not so dusty, making it better for horses. It is perennial and produces a mass of long fibrous roots, which hold the soil, making it useful for permanent pasture on hillsides which are liable to wash. When used alone sow from eight to ten pounds per acre. Per lb., postpaid, 35c; 100 lbs., write for prices.

\section{Red Clover (Trifolium Pratense)}

The standard clover for all purposes, either has, pasture or for improving and enriching the soil. It is hardy and succeeds well on any good soil. It yields the heaviest crop of any clover except alfalfa, and makes superior hay-especially if mixed with timothy-either for dairy cows or for general use. Sow from twelve to fifteen pounds per acre, being careful to get it evenly distributed over the ground. Per lb. postpaid, 30c.; 100 lbs., write for prices.

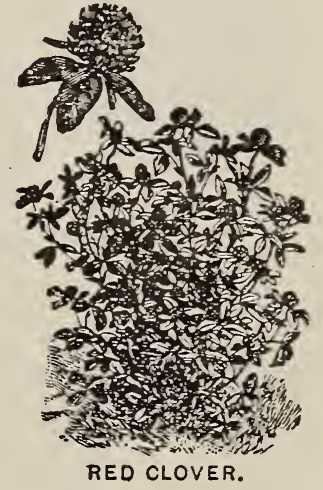

\section{White Dutch Clover (Trifolium Repens)}

A small variety having a white blossom. It is of a vining nature, spreading rapidly and will soon cover bare spots if the stand be even. It does not attain sufficient height to be profitable for hay, but is superior for pasture, either for cattle or sheep, and unsurpassed for the production of honey. It also makes a beautiful lawn when mixed with Blue Grass. If sown alone, use six to eight pounds per acre. Per lb., postpaid 35c; $100 \mathrm{lbs}$., write for prices.

Fancy for lawn. Per 1b., 40c; 100 lbs., write for prices.

\section{Bokhara, Sweet or Honey Clover (Melilotus Alba)}

A rapid growing, white flowered sort; excellent for bees. Sow ten pounds per acre. Per 1b., postpaid, 35c.

\section{Crimson, or Scarlet Clover (Trifolium Incarnatum)}

Highly recommended for pasture and fertilizing purposes. It is a thrifty annual, growing from twenty to thirty inches high, and has a beautiful crimson bloom. It germinates quickly, grows rapidly and stools abundantly. Sow from twelve to fifteen pounds to the acre, and harrow it from twelve to fifteen pounds to the acre, and full bloom. with a light harrow. Cut for hay wh
Per lb., 25c; $\mathbf{1 0 0}$ lbs., write for prices.

\section{Esperette, or Sainfoin (Onobrychis Sativa)}

A deep rooting, perennial legume, extensively cultivated on dry, calcerous soils which are too barren for clover or alfalfa. It is rather difficult to establish, as plants are easily killed when young, but when once rooted, will live from ten to twenty-five years. Sow 50 pounds per $8 \mathrm{cre}$ from ten to twenty-five years. Sow 50 pounds 


\section{[Grass and Clover Seeds--Continued]}

\section{TIMOTHY SEED}

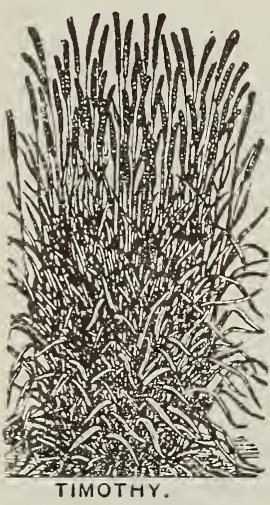

Timothy is a native of Europe, but long ago naturalized in America, where it ranks as by far the most important of hay grasses. Its popular name, by which it is now known the world over, refers to Timothy Hanson, who did most to make it known and appreciated. On moist, loamy or clayey soil it produces a larger hay crop than any other grass. It is not so well suited for light, sandy soils. Though preferring a moist, temperate climate, it withstands drought and extheme heat and cold. Its hay is very nourishing and can be preserved for a long time. It should be cut when flowering, as, if left later, the hay becomes hard and coarse. It is often sown along with red clover, and the nutritive value of the hay is greatly increased by the mixture. Height, 2 to 3 feet. If sown alone, lb., postpaid, 20c. $100 \mathrm{lbs}$., write for prices.

\section{Red Top (Agrostis Vulgaris)}

RED TOP (Agrostis Vulgaris)

In Pennsylvania and states further south, this is known as Herd's Grass, a name applied in New England and New York to Timothy. It is a good, per ennial grass, standing our cli mate well and makes good pastures when fed close. Is valuable for low, wet meadows, producing a large return in good hay. When sown alone, use twenty-eight pounds of the chaff seed per acre. Sow in spring or fall. Fancy (cleaned from chaff). Sow eight to ten pounds per acre. Per lb.,.30c; 100 lbs., write for prices.

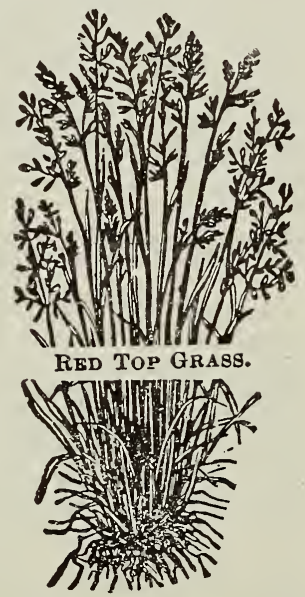

\section{Tall Meadow Oat Grass (Avena Elatio)}

A hardy perennial much used in the south and west. Its roots penetrate deep, and it thrives on any good soil. It yields a heavy crop and is valuable for both meadow and pasture. If used alone, sow from thirty to forty pounds per acre. Per lb., postpaid, 35c; $100 \mathrm{lbs}$., write for price.

\section{Brome Grass (Bromus Inermis)}

A perennial grass valuable for binding the soil of embankments and on account of its ability to resist both drought and cold. On light, dry soils it is used for both hay and pasturage, but is not recommended for locations where better grasses will succeed. Should be used at the rate of twenty pounds per acre. Per lb., postpaid, 30c; $100 \mathrm{lbs}$., write for prices.

\section{English Rye Grass (Lolium Percune)}

This makes a quick growth very early in the spring, and is adapted for cool, moist locations, recommended for fall seeding on Bermuda-grass lawns in the south, giving them a bright green appearance all winter. Twenty-four pounds to the bushel; three bushels to the acre. Per lb., postpaid, $25 \mathrm{c} ; 100 \mathrm{lbs}$., $\$ 8.00$.

\section{Italian Rye (Lolium Italicum)}

This is distinct from the preceding, being of much larger and stronger growth, with large, broad, glossy green blades.

It succeeds best in moist, fertile soils. About twenty pounds to the bushel; three bushels to the acre. Per lb., postpaid, 25c; 100 lbs., \$8.00.

\section{Orchard Grass}

No farmer should be without a small field of Orchard Grass, as in many respects it is superior to all otleer grasses. It stands the drouth, grows well in the shade, does well in wet or poor ground, and is splendid to prevent worn out fields from washing. This grass furnishes excellent pasturage three weeks before any other, and after close grazing ten days' rest is sufficient for another growth. Cows fed on this will produce more and richer milk than on blue grass. It makes a very heavy sod and when well set remains for many years. It is especially adapted for winter grazing, as it remains green all season. Per lb., postpaid, 30c; 100 lbs., write for prices.
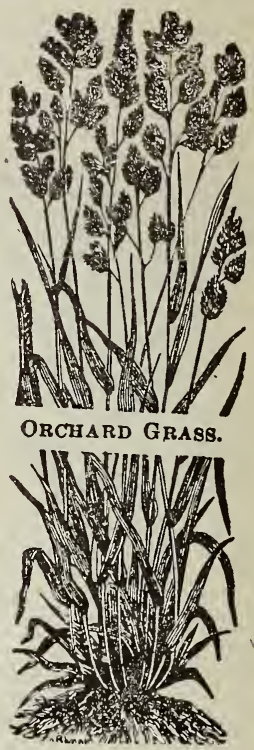

\section{Meadow Fescue (Festuca Pratensis)}

A perennial variety growing three to four feet high. It roots deep, but resisting drought better than most grasses. It succeeds on any ordinary soil; yields a heavy crop of superior hay; one of the best grasses for pasturage. Valuable to mix with other kinds. Use 20 pounds per acre uable to mix with other kinds. Use 20 pounds per acre
when sown alone. Per 1b., postpaid, 25c; 100 1bs., write for prices.

\section{Canadian Blue Grass (Pea Compressa)}

A hardy perennial growing on poorest and dryest soils. Short (6 to 8 inches), hard and wiry, but high in nutritive value. Decidedly blue in color. Stems flattened. Invaluable for use on steep places or exposed situations. Sow three bushels to acre. Per lb., postpaid, 25c; 100 lbs., write for prices.

\section{Kentucky Blue Grass}

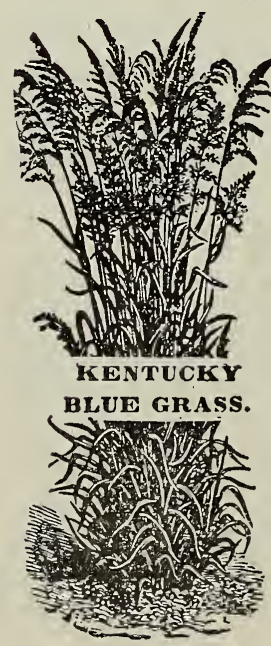

This makes the best, sweetest and most nutritious pasturage for all kinds of stock. Kentucky has long been famous for its high bred horses and its blue grass pastures. It is now possible to establish on most any farm a blue grass pasture of greenest verdure which will give very profitable returns. This grass is the first to start up in the spring and remains green until snow flies in the fall. It is very hardy and is uninjured by cold or dry weather, hot sun or tramping of hoots. The roots are so thick and stout as to form a tough sod. Blue grass requires about two years to get well started and for that reason it is often sown in mix. ture with other grasses. It will do well on almost any land. Sometimes called "June Gas,, , Sometimes callod "Sterom grade seed required to the acre. grade seed required to the acre.
Per 1b., postpaid, 35c; 100 lbs., Per lb., postpaid
write for prices. 


\section{(Grass and Clover Seeds-Continued)}

\section{Wild Rice for Seed}

As an attraction for wild fowl it cannot be equaled. In large ponds and lakes it purifies the water and affords a refuge for small fry from the large fish, also furnishing them plenty of food from the animalculae upon its stalks. For planting in fish ponds it is especially desirable. It also does well along the shores of marshes, and makes a good hay. In the south two crops can be cut, and all cattle are very fond of it. Per lb., postpaid, 35c.

\section{How to Make a Lawn}

The ground should be spaded deeply and thoroughly, and a good compost of decomposed and finely pulverized manure or rich loam spread over the ground. It would be well, also, to give a sprinkling of bone dust. Then use a slanted tooth harrow and a light or medium roller until the soil is smooth, even and firm. Then sow the seed and harrow again and smooth off with a common garden rake. When the grass has grown 2 or 3 inches in height use the lawn mower, gauged to cut full one inch above the ground; repeat the same as often as it grows to that height. The repeat the same as often as it grows to that height. The weeds and foul grass can be kept down and destroyed by
the repeated mowing. If this is neglected they will spread and take possession of the soil, but being constantly clipped, the leaf and seed stalks are destroyed and the foul vegetation disappears.

As a guide for the proper quantity to order, we may state that one pound of Fancy Mixed Lawn Grass Seed is sufficient to thoroughly sow an area of 20 feet by 15 feet300 square feet. It should be borne in mind that in order 300 square feet. It should be borne in mind that in order
to produce the best results grass seed for lawns should be sown at least thrice as thickly as if sown for hay.

As soon as the grass has become well established a dressing of good Lawn Fertilizer is necessary to keep up that beautiful fresh appearance.

\section{LAWN GRASS}

\section{Our Own Mixture}

This is especially fine. Carefully prepared. Will give best results. Per lb., postpaid, 35c; by express, 10 lbs., $\$ 2.25$.

\section{FIELD AND MISCELLANEOUS FARM SEEDS}

\section{Millets}

If sent by mail add $10 \mathrm{c}$ per $\mathrm{lb}$. for postage.

GERMAN MILLET-No other grass or forage plant has been able to produce the enormous yield of this plant. It has produced four to five tons of hay to the acre, and from 70 to 80 bushels of seed. It is sown in the spring on newly broken prairie, and after harvesting it leaves the ground in the finest condition for wheat. Sow 25 to 40 pounds to the acre. Ib., postpaid, 20c; 100 Ibs., \$4.00.

MANITOBA OR HOG MILIET-Very rich and thus espeeially valuable as a hog food. A very much prized peculiarity of this millet is that the seed ripens while the stem is yet green, thus if cut promptly can be threshed for the seed, while the hay after being threshed will make excellent fodder. Sow same as other millet. Ib., postpaid, 20c; 100 lbs., \$4.50.

NEW SIBERIAN OR RUSSIAN MILLET-Is claimed to be the most wonderfully productive and satisfactory forage plant, possessing in a superior degree all the essential merits of any of the older sorts-exceeding them by far-besides many other points of excellence that distinguish it and render it a most valuable addition to the list of forages, and, if the claims are well founded, destine it to take front rank, and if not lead all the rest. The claims made by its introducers are that it is from two to three weeks earlier than the German Millet, is a much heavier cropper, that the hay is much finer, stalks more elastic and grow. ing much taller, that it is rust proof, and chinch bugs do not relish it, and being of stooling habit, requires much less seed per acre. You should try it. Lb., postpaid, 20c; 100 lbs., \$4.50.

EARLY FORTUNE-A most promising new sort, of which astonishing yields are reported. It is very early and claimed to be rust proof. Per lb., postpaid, 20c; 100 lbs., \$4.50.
HUNGARIAN MILLET-This grass resembles Millet very much. It is of fine growth, and makes an excellent hay. It has numerous succulent leaves, which furnish an abundance of green fodder, taken by all kinds of stock. Sow 25 to 30 pounds to the acre. Lb., postpaid, 20c; 100 Sow 25 to
lbs., $\$ 4.50$.

\section{Buckwheat}

SILVER HULL-A very good and popular variety Grain is of light gray color, rounder than the common; ha a thin husk; matures earlier and yields heavy. A good milling variety. 'Per lb., postpaid, 15c; 100 lbs., write for prices.

JAPANESE-This variety excels all others; yield much heavier; ripens one week to ten days earlier; stands up better and makes better flour. Excellent for bee pasture. Per lb., postpaid, 15c; 100 lbs. write for prices.

\section{Dwarf Essex Rape}

Main standby of the English farmer in raising choice mutton. Perfectly hardy, and of remarkable fattening properties. Easily grown. One acre will pasture 36 head two months, and lambs will make a gain of from 8 to 12 pounds per month. Pigs and cattle are also extremely fond of it. A very rank grower and bears heavy manuring and high cultivation. Sow at intervals of several weeks and se cure a supply of good feed. Sow in June. Rape should be fed in August, though if a first crop be cut about four inches from the ground an atfer growth would be useful later. For breeding flocks a piece should be sown first week in July or later. Does well sown with oats. If soi is rich and clean sow broadcast, otherwise in drills and cultivate same as corn. Poultrymen will do well to grow a small patch to feed green to growing chicks. Can be sown on wheat stubble, furnishing excellent pasture late in the fall. Broadcasted it takes 8 to 10 pounds to the acre. Lb., 25c, postpaid, express or freight; 10 lbs., $\$ 1.00 ; 100$ Ibs., \$7.50.

\section{FIELD PEAS}

"Peas could be made to bring more nitrogen to the soils of this country every year than is now purchased annuall by the farmers at a cost of millions of dollars." - (Yearbook of the U. S. Department of Agriculture.)

For the northern states there is no crop of greater value than Field Peas and none is more neglected, which can only be attributed to a lack of knowledge as to its merits. Whether for fodder, in mixture with oats, sown at the rate of two bushels each per acre, or the Peas sown alone at the rate of three bushels per acre for plowing under, there is no crop that we can so strongly recommend for more extended culture.

\section{Canada Field Peas}

This pea is adapted to cultivation in Washington, Oregon and British Columbia. This should be sown in early spring, at the same time as grain, using from one to one and a half bushels of peas and an equal quantity of either wheat or oats or barley. The crop is ready to cut for hay when the dominant variety in the mixture is nearly ripe. If there is more peas than grain then the yellowing of the peas and pods marks the time for cutting, or if the grain exceeds the peas, then crop should be cut when the grain is in the dough stage. Per lb., postpaid, 20c; 100 lbs. write for prices.

\section{Vetches, or Tares}

One of the best forage plants that can be grown on the Pacific coast. Often called Fall Vetches. This is a species of the pea, and is grown very extensively in Oregon and Washington. It furnishes an abundance of excellent feed ither green or dried. The seed should be mixed with an equal weight of some variety of wheat, oats or rye having a stiff straw, and the mixture sown at the rate of two bushels per acre. Weight 70 pounds per bushel. Sow in the early spring. Per lb., postpaid, 20c; 100 lbs., \$5.00

\section{Vetches, Sand or Winter (Vicia Villosa)}

This variety thrives on poor, arid, sandy soils. It is sown either in the fall or spring, and is generally mixed with rye, which serves to support the plants. It grows to a height of htree or four feet, and can be cut twice; first, as soon as the bloom appears and afterward for seed. The plant is perfectly hardy and makes a very nutritious food. Per lb., postpaid, 25c; 100 lbs., \$12.50. 


\section{[Field and Miscellaneous Farm Seeds -Continued]}

\section{Sugar Cane, Early Amber}

The high value of northern grown sugar cane for fodder and enslia is becoming rapidiy known. It may be made and ensliage is becoming rapidly known. It may be made August until the following spring. When fed down young as a pasture it grows rapidly again. It also withstands severe drouth with the best of this kind of plants. As a fodder and for winter feed it is one of the most economical. The Early Amber is the best variety for sugar, and it matures quickly. Per lb., postpaid, 25c; 10 lbs., \$1.00; 100 lbs., \$5.00.

\section{Soja Bean}

A very valuable fodder plant, either for feeding green or for the silo. It is a rich food and is unsurpassed for forming flesh. Sow 30 pounds per acre in the spring after the ground becomes warm. Like clover, it improves the soil by drawing nitrogen from the air. Very productive. Per lb., postpaid, 25c; 100 lbs., $\$ 9.00$.

\section{SEED GRAINS}

\section{Re-Cleaned}

We give special attention to our Seed Grain Department. Having one of the best cleaning plants in the Northwest, we aim to have our prices as low as possible consistent with quality.

Seeds cannot be manufactured and the value of them always depend on the quantity that has been produced, which is found to be of a quality that meets the standard suitable for seed purpose. When shortages develop prices go up. When the supply is abundant prices go down.

Owing to the very great shortage of grains this year we are unable at the time of going to press to say just what varieties we will be able to procure or what price we can quote.

Therefore we are listing only the standard varieties. When ready to buy, write us giving quantity wanted and we will quote you at once.

\section{Recleaned Wheat-Spring}

BLUE STEM-A remarkable, semi-hard spring wheat, yielding large crops, free from rust. The millers here pay more for it than for any other sort. It is fully equal to the old Fife Wheat, and yields a very much larger crop. It is now the main crop in the northwestern states, and the great milling kings use it for their leading grade of flour. It has been the most reliable variety year after year, yielding a good crop when other kinds failed. One of the best varieties for hay.

SONORA-Light colored small kernel, medium hard. A variety much used for breakfast foods.

\section{White Australian}

Light colored large kernel, somewhat resembles blue stem. A variety sometimes used for hay.

\section{Recleaned Wheat-Winter}

JONES FIFE-A medium hard red variety, less likely to shell than many.

MARTIN AMBER-Medium light kernel, much used for hay and cereal foods.

GOLD COIN-Light colored grain, very hardy and a good yielder.

\section{RECLEANED RYE}

Rye is a valuable and very hardy crop producing green fodder either in the arly spring or lat sidered preferable to wheat because it is harder and protects the young grass, matures before other crops come in and can be sown on soil too poor for other cereals.

SPRING RYE-Spring Rye is an excellent catch crop where winter grain has been killed out, or for sowing where a fall crop has not been planted. If desired it can be turned under and made to answer a good purpose in adding to the fertility of the soil. We call particular attention to the fact that we offer genuine Spring Rye. Many have been disappointed in receiving winter rye as a spring vabeen disappointed in receiving winter rye as a spring va-
riety, and we wish to emphasize the fact that we sell the Genuine Spring Rye, sown in the spring and harvested the

\section{Sunflower, Mammoth Russian}

The largest and most productive variety. Heads often 12 to 20 inches across. Every farmer should plant a few rows at least. It makes one of the very best of foods for poultry; a great egg producer. 1 lb., postpaid, $25 \mathrm{c}$.

\section{Kaffir Corn}

An excellent fodder plant, yielding a large crop of fodder during a season. Grows four to five feet high; upright stalk, with numerous large leaves. Greatly relished by cattle and horses. The seed crop is also heavy, sometimes yielding 60 bushels to the acre. It does best sown in drills three feet apart, using six to eight pounds of seed per acre. Per lb., postpaid, 20c; 100 lbs., $\$ 4.00$.

\section{Broom Corn, Improved Evergreen}

This is the most popular variety of broom corn to grow for the market the brush being firm and of good length, and retaining the light green coloring when properly cured. Per 1.b, postpaid, 20c.

same season. We now offer an extra fine grade and to in sure receiving all your requirements we advise placing your order early. 100 lbs., \$2.25.

WINTER RYE-The value of Winter Rye is becoming more apparent every year. It is much hardier than whea and can be grown on a greater variety of soils, even on soil that would not produce a fair crop of wheat. It will thrive even in dry seasons and on light sandy loam. It is grown not only for grain, but for fodder and soiling purposes also. When sown in the autumn it starts up very early in the spring and is ready to cut or pasture when about six inches high. It is often plower under at this stage of its growth as it is then in condition to add great fertility to the soil. Rye does not exhaust the soil as do other grains and can be cultivated longer on the same land than any other crop on the farm. $100 \mathrm{lbs}$., \$2.25.

\section{Barley}

BEARDLESS BARLEY-Very early and free from beards; handles as easily as Oats making a stronger feed, Makes magnificent hay for work horses. Sow as early as you can; frost will not hurt it. $100 \mathrm{lbs} ., \mathbf{\$ 2 . 2 5}$.

WHITE HULIJESS-The earliest variety of Barley known. If sown in September will ripen about the end June. Grain is flinty and translucent not unlike wheat, and weighs about $60 \mathrm{lbs}$. to the bushel. It will yield a magnif weighs about $60 \mathrm{lbs}$. to the bushel. It will yield a magnif$1 \frac{1}{2}$ bushels per acre. This is less than common barley. 100 lbs., \$2.50.

HANNA TWO ROWED-A famous and popular barley, highly recommended. 100 lbs., $\$ 2.25$.

\section{Recleaned Seed Oats}

We always aim to have a selected, re-cleaned stock of standard varieties. Write for prices.

\section{Kill the Smut in Your Grain}

If there is smut in your Wheat seed destroy the smut and persist in it; you should also insist that your neighboring wheat growers endeavor to destroy the smut. This trouble is becoming very prevalent. Smut must be destroyed if wheat is to keep up its high grade of milling qualities.

\section{Remedies for Smut}

Bluestone, market price; use $1 \mathrm{lb}$. to $5 \mathrm{bu}$. grain.

Formaldehyde, $1 \mathrm{lb}$. Bottle, 40c; use $1 \mathrm{lb}$. for 40 to 50 bu. of grain.

\section{Flax Seed}

RE-CLEANED FOR PLANTING-Per lb., postpaid, 20c; 100 lbs $\$ 4.50$.

GROUUND FLAX-For medicinal uses. Per lb., 10c; 100 lbs., \$4.50.

OII MEAL—For feed purposes. 100 lbs., \$2.75. Special prices in quantity.

\section{BIRD SEED}

CANARY-Per lb., 10c; 3 lbs., 25c.

HEMP - Per lb., 10c; 3 lbs., 25c.

RAPE-Per lb., 10c; 3 lbs., $25 c$.

MILLET-Per lb., $7 \mathrm{c}$; 10 lbs., 50c.

CUTTLE BONE-2 for $5 \mathrm{c}$

SUNFLOWER-Per lb., $10 \mathrm{c}$. 


\section{INCUBATORS AND BROODERS}

\section{THE MODEL INCUBATORS}

Made by Chas. A. Cyphers

(For fuller description wrte for Catalogue.)

The name of Chas. A. Cyphers is known to every poultry raiser who knows anything about the various incubators and brooders on the market. He is now putting out the Model Incubators, which is in every way the best and most popular incubator made, backed by years of experience in the manufacture of incubating machines. The outer case of the Mrodel Machine is chestnut, which holds a glue-joint better than any other wood and will not warp. It also makes ter than any other wood and will not warp. It also makes a most handsome appearance. Each machine has double The heater is constructed of the best grade of galvanized iron, heavily insulated with an asbestos jacket, and placed outside the incubator. In this improved machine the air does not return from the egg chamber to the heater, but is exhausted through a pourous bottom in the hatching chamber directly to the outer air, fresh warm air taking its place.

The Model contains the most perfect heat controller in existence. Strong, yet active; sensitive, yet positive-perfect in action.

Improvements on Model Incubators for Season of 1908-9 are most valuable.

\section{FIREPROOF HEATING APPLIANCE}

The "'Model Patent Fusible Link" puts the flame out should it smoke. With this device it is impossible for the lamp to explode. It makes the Model Heater safer than a house lamp. Furnished free this season with Model Incubators. Links sold separately to old customers.

Church's Seed Store.

Sirs:- I received the lamp all $O . K$. The hatch is off. I have hatched in the Cyphers Model 220 chicks out of 223 fertile eggs. I think that is not so bad for a new hand. I recommend the Cyphers Model to old and new hands in the chicken business. Yours respectfully G. H. CRANE, Rockford, Wash.

The Model Corrugated Leaf, Compound Thermostat

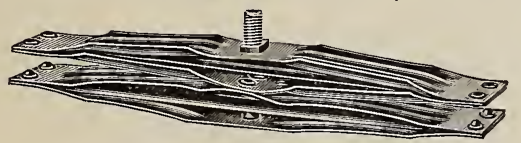

This thermostat has three corrugations in each leaf; is exceedingly strong and rigid; is not easily damaged; and by the different coefficient of expansion between the two metals of which it is made is transmitted to the controlling device without any loss of movement.

The Model Incubator gives a perfect heat controll, which stimulates and holds the germ development uniformly constant and normal, as a hen. This wonderful hatcher has almost a perfect balance in ventilation and humidity, and suppiles all the vitalizing principles found under the incubating hen.

\section{PRICES OF MODEL INCUBATORS}

No. $1-140$ to 150 eggs.

No. $2-240$ to 250 eggs

No. 3-360 to $\mathbf{3 7 0}$ eggs

No. 4-Special 410 to 420 eggs

$\$ 25.00$ $\mathbf{3 5 . 0 0}$ 43.00
$\mathbf{4 7 . 0 0}$

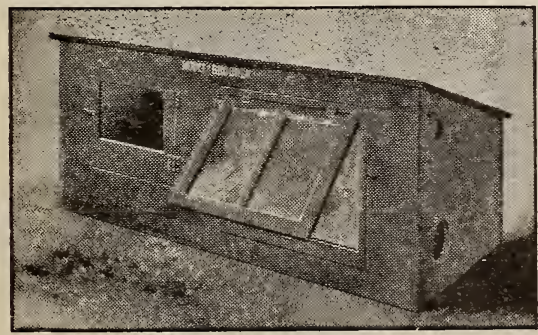

Model Colony Brooder

This brooder, an entirely new design last season, once met with popular favor; and it is safe to say that no brooder ever gave as universal satisfaction as did this brooder. It excels all other artificial mothers as much as incubators of $\mathrm{my}$ design do all other hatching devices. It stands without equal in design as well as in efficiency. Price \$20.00.

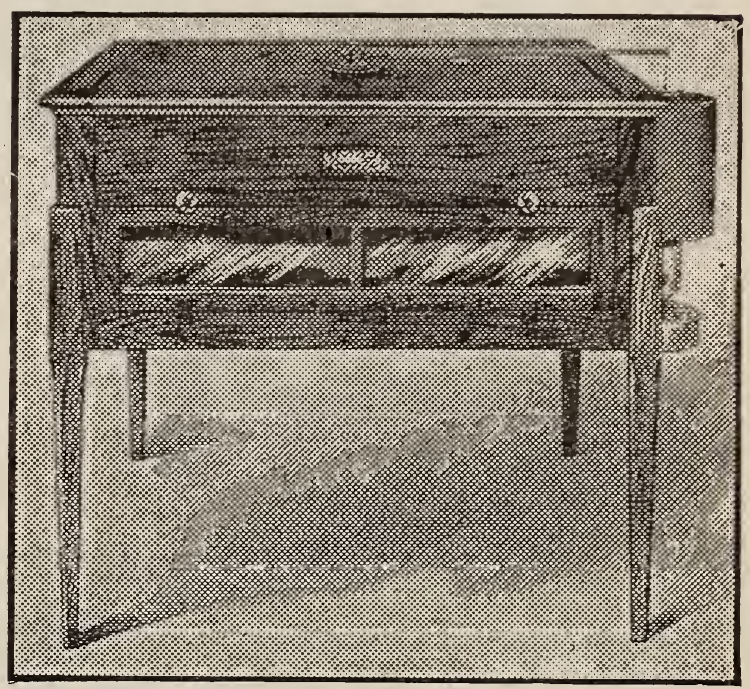

Model No. 2

\section{Church's Common Sense Outdoor or Indoor Brooder}

Caring for the roung chicks after they are hatched is a more difficult task than hatching them. There are a number of incubators on the market that will hatch a good percentage of fertile eggs placed in them, but these same manufacturers have neglected to a great extent the brooder

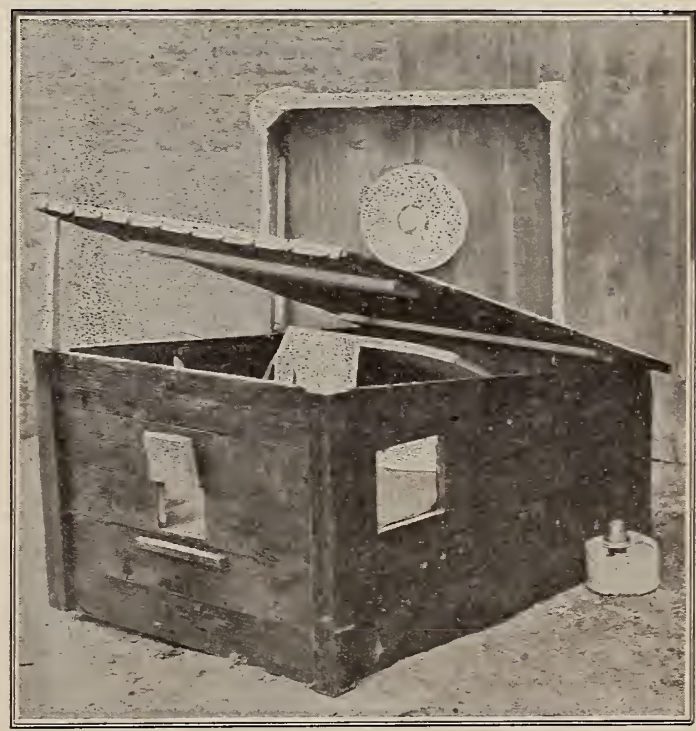

question. The demand for indoor and outdoor brooders is about the same. Many more outdoor brooders would be sold if the price were the same. To meet the popular de 


\section{(Incubators and Brooders-Continued)}

mand we are manufacturing the COMMON SENSE BROODER, suitable for indoor or outdoor use. This brooder has two separate compartments, thus supplying a temperature under the hover that is at all times several degrees warm. er than that of the chamber outside. Instead of being standard size, 36 inches square, it is $33 \times 48$ inches, thus ellowing much more rom in front for feeding and exercise. It is built thoroug with Mahthoid roofing making it water proof. In order to avoid crowding in corners the heating iron is made 12 inche sin diameter, thus giving 36 inches in circumference or ample room to start with, for 100 chicks. For heating we use Church's Safety Lamp, which will produce more heat with less smoke and oil than any on the market. Price \$12.50.

\section{Model Double Indoor Brooder}

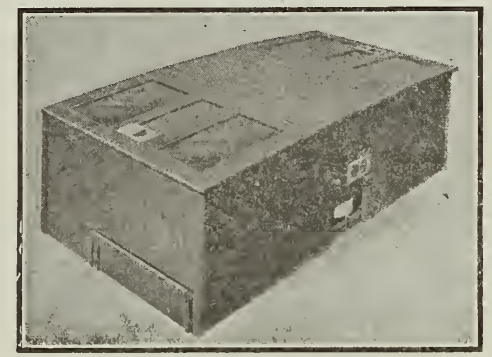

This brooder is made both single and double, the latter to take the place of sectional brooders. In a sectional brooder a surplus lamp heat is dissipated in the outer air. In a Model Brooder the lower temperature is equable and the surplus heat keeps up the temperature of the nursery. The double brooder is partitioned in the middle making two distinct compartments, while it takes but one lamp to heat both sides. Price $\$ 19.00$.

\section{Lampless Brooders}

We have made arrangements to handle the latest improved

\section{Fireless or Lampless Brooders}

We have been unable to secure an illustration of it for this catalogue, but you can call and see it or write for descriptive circular.

\section{Brooder Fixtures.}

To those wishing to make their own brooders we can furnish fixtures for the Common Sense Brooders. In the past three years we have sold hundreds of these to poultrymen, and wherever used they have given satisfaction. The fixtures include Safety Lamps, Thermometer and set of Irons. Price, Complete, \$3.25.

We have no printed directions for making, so it is advisable to secure one already set up as a pattern.

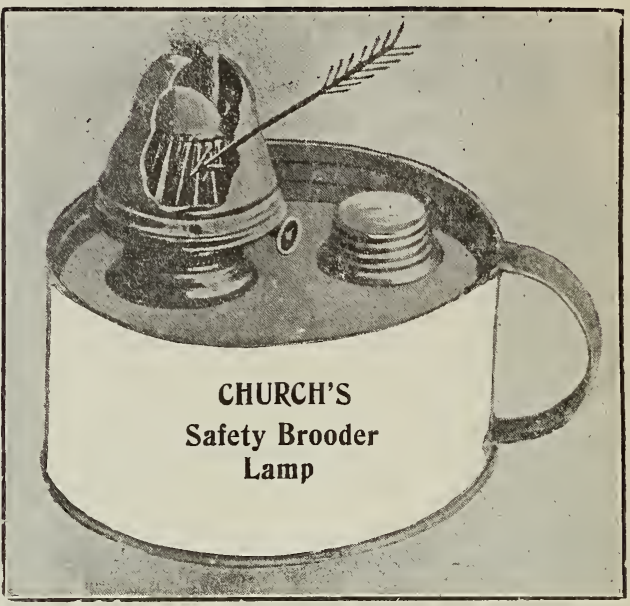

Church's Safety Brooder Lamp

The latest and best lamp for the brooder; requires no chimney; never smokes, but burns a steady flame. The air fingers carry fresh air direct to the flame. This gives perfect rnbustion and more heat for a given amount of oil than with any other burner. A water chamber is on top of lamp to keep oil and burner cool, and prevent any chance of explosion. Price, $\$ \mathbf{1 . 0 0}$.

Large Lamp for Model Incubator and Brooder............ $\$ 1.10$ Small Lamp for Model Incubator and Brooder............ 1.00 No. chimney burners with collar.................................. .50 No. 1-Burners, postpaid.......... $\mathbf{. 3 0}$

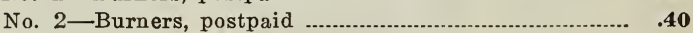
No. 3-Burners, postpaid..............

No. 1-Chimneys, postpaid..........................................................

No. 2-Chimneys, postpaid._..30c

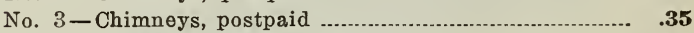

No, 1-Wicks, postpaid, per doz................................

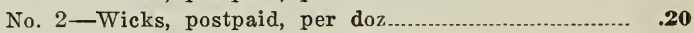

No. 3-Wicks, postpaid, per doz

\section{Mann's Green Bone Cutters}

MANN'S NO. 5 BHas four knives, large cylinder, and has the lat est patent (automatic, governing spring feed) which makes it one of the best. Price, $\$ \mathbf{1 0 . 5 0}$.

NO. 5 B. M.-Mounted on iron stand, no expense to set it up. pense to set it up. the bone. Patented authe bone. Patented automatic governing spring
feed. Cylinder, 6 inches diameter, 4 inches deep. Cutter plate has four knives instead of three. er than other types costing twice as much Weight 85 pounds. Price, $\$ 14.00$.

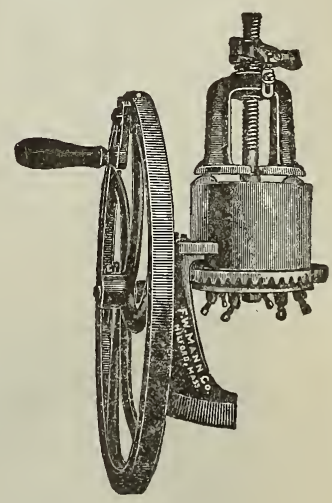

No. $5 \mathrm{~B}$

A good Bone Cutter is almost indispensable if you want to get the best results. They pay for them= selves many times over. 


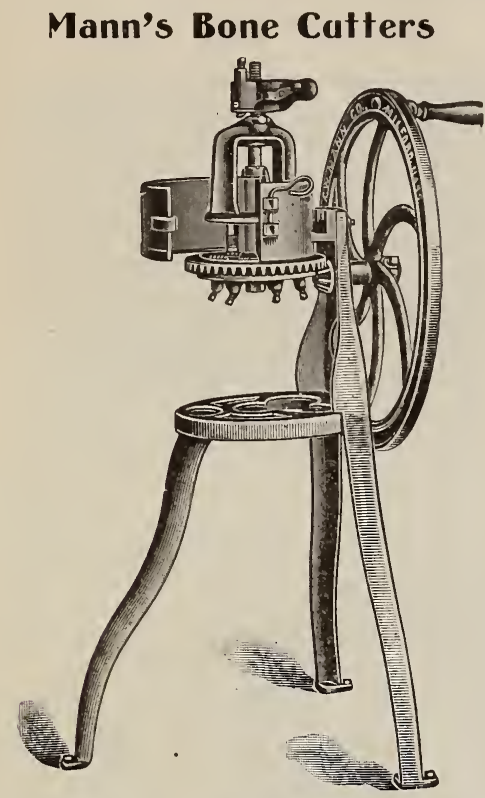

MANN'S NO. 7-The New No. 7 is mounted on strong iron stand, and has patent automatic governing spring feed. Large, open-hinged cylinder giving instant access to all working parts; has six knives, gear guard, anti-clog device, heavy balance wheel and other improvements. (See cut.) Price, \$15.50.

MANN'S 'NO. 71/2-Adapted to run either by hand or by power, without any change. The particular advantage of it can be operated by hand just as easily as the No. 7 . Thus, it is always ready for use. It is recommended even if you have no power at present, for should you get power in the near future, you need be at no further expense. Price, \$21.00.

MANN'S NO. 11-About the same as No. $7 \frac{1}{2}$, except that it has a larger cylinder and greater holding capacity, different design and larger table. Price, \$33.00.

\section{The Wilson Dry Bone Mill}

No. 1 is a practical mill, grinding all kinds of shells, crockery, grit, burnt or dry bone feed, etc. Instantly adjusted to grind coarse or fine. Weighs 33 pounds. Diameter of hand wheel, 20 inches. Price, $\$ \mathbf{5 . 5 0}$.
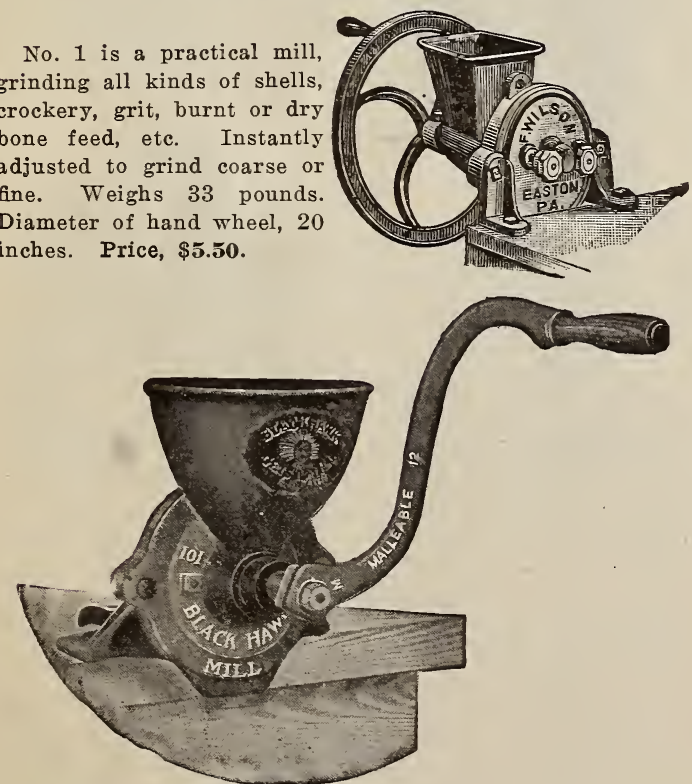

WITH A BLACK HAWK MILL in the house you crack the corn or grind any kind of grain to whatever degree of fineness you desire or which ever will best suit the use or condition of your chickens. Its wide range of usefulness, its durability and small cost will appeal to the family in town with a small flock in the back yard, and it has large enough capacity to meet the needs of those in the large enough capacity to meet the needs of those in th
country who keep poultry on a big scale. Price, $\$ 3.50$.

\section{Silver's Clover Cutter}

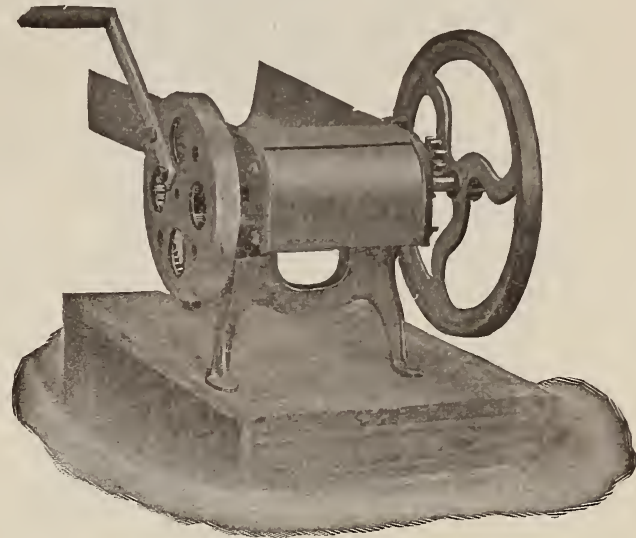

A Practical, Inexpensive Machine for Poultry Raisers This machine has been specially designed for cutting chis machine has been specially designed for cutting 1y demonstrated by poultry raisers that cut feed is one of the necessities in successful poultry raising and the above cut represents the best machine yet produced for this purpose. It has a heary fly wheel, which insures easy running, and it will cut faster than machines costing about twice the money. Will cut a bushel of clover easy in ten minutes. It is intended to be mounted on a box or bench the proper height for the convenience of the operator. Weight 60 pounds. Price, $\$ \mathbf{7 . 5 0}$.

\section{"New IModel" Clover Cutter for Poultry} Removable Steel Knives-Adjustable Cutter Bar-Runs Easy-Cuts FineIs Durable

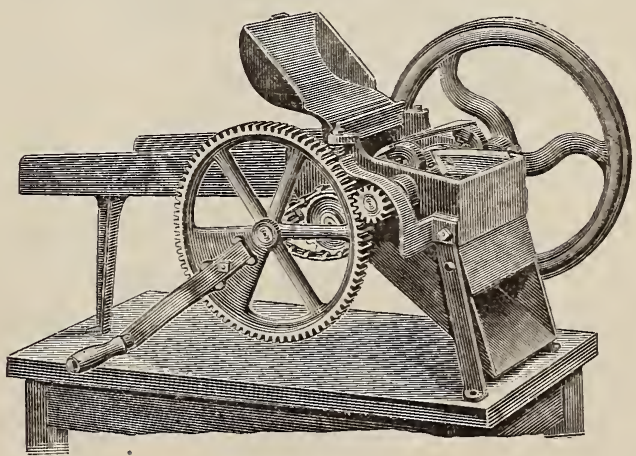

FIG, 770

The "New Model" Clover Cutter is designed for cutting, either green or dry, such growths as clover alfalfa, vegetable tops, etc., into $1 / 8$ inch lengths. These growths are the cheapest and most productive egg-forming poultry foods for cold weather.

The "New MIodel" is made only of iron and steel, from entirely new patterns. It is a strong feeder, has large capacity, runs unusually easy and will do perfect work indefinitely. Length over all $281 / 2$ inches.

The machine is intended to be mounted on a box or bench at any height to suit the operator. Price, with four 7-inch knives, extended shaft and pulley for power, $\$ \mathbf{1 4 . 0 0}$. 
Banner Root Cutter No. 7

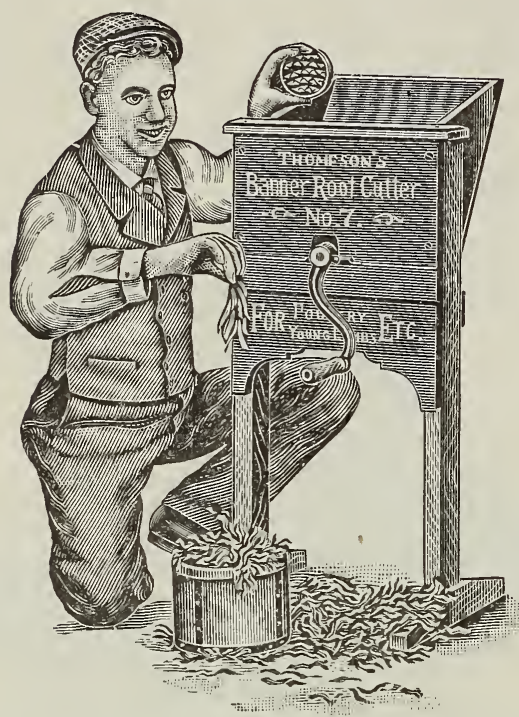

This is an illustration of the Banner No. 7, Root and Vegetable Cutter, a machine made expressly for poultrymen. It quickly cuts vegetables into long, round, ribbonlike slices, that resemble a bunch of angle worms, which fowls readily eat up to the last morsel. The value of this kind of food once or twice a day, as an egg producer, is unequalled. It also puts the fowls into a fine, ealthy condition, acting as a general tonic and laxative. This machine will pay for itself in a short time. It is a valuable addition to the poultry house and comes to us highly recommended by the best poultry experts in the country. Price, Banner Root Cutter, \$5.广ิ0.

\section{Paper Egg Boxes}

Intended for use in delivering eggs to private families. If you have a select egg trade you should use this box. They ship knocked down at a low rate. 1 doz., 20c; per $100, \$ 1.00$; per 1000, $\$ 9.00$.

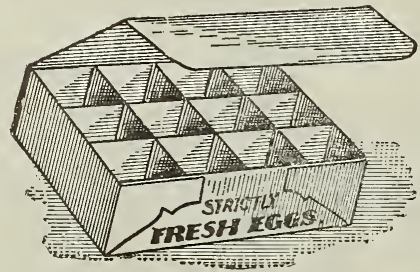

\section{Reliable Egg Carrier}

Nicely painted; equipped with the very best fillers. Patent top and sling handle. Holds twelve dozen. (See cut.) Price, each, 75c

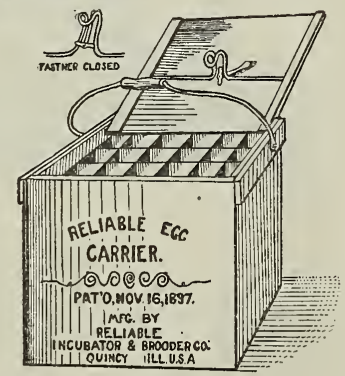

\section{Sanitary Self-Feeding Boxes}

Made of heavy galvanized iron. Soon pays for itself in preventing waste of feed. For keeping grit, shells and charcoal before the fowls at all times. Price, $75 \mathrm{c}$.
Standard Egg Testers

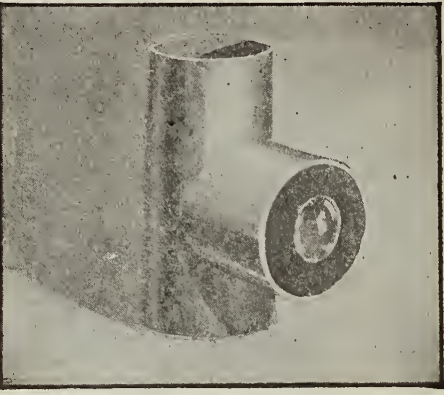

Best lamp tester made. Will fit any No. 2 burner. Price, 25c; postpaid, 40c.

High Grade Tested Thermometers
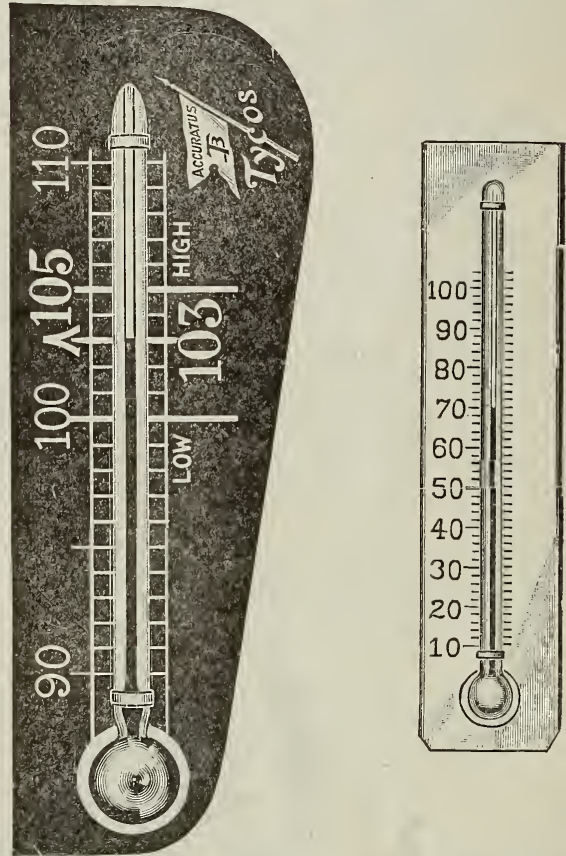

The best incubators and brooders manufactured are worthless unless the thermometers therein are correct. worthless unless the thermometers therein are correct. facturers to be thoroughly and expertly tested before they are offered to the public. Price, incubator thermometers, $75 \mathrm{c}$ postpaid. (Hang it from the top of egg chamber so it touches the eggs.) Brooder thermometers, 50c postpaid.

\section{Wire Nests}

Plain Nests. These nests are strongly made from heavy japanned steel wire and will last a lifetime. They are injapanned steel wire and will last a lifetime. They are intended to be fastened to the wall with screws or screw. hooks. There is no room on them for lodgment of lice or far superior to wooden boxes. Price, each, 20c; per dozen, $\$ 2.00$.

\section{Glass Nest Iggss}

Perfect in shape and easy to clean. Three for 10c; per doz., 30c; postpaid, 55c.

\section{Hygea Lice-Killing Nest Egg}

A combined nest egg and lice killer. By simply using it in the nests in the same maner as an ordinary nest eg. is used laying hens are cleared of lice and mites, and are able to occupy the nests with comfort. Do not accept worthless substitutes. Each, 10c; doz., postpaid, 85c. 


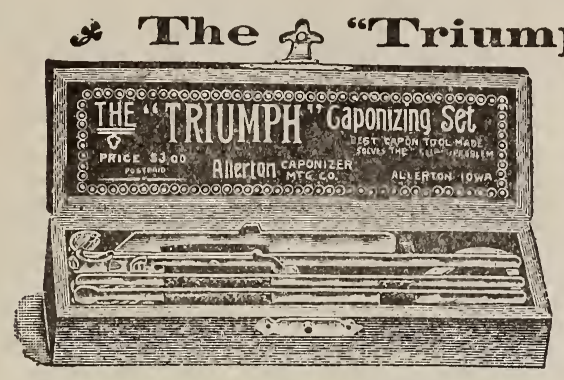

Poultry Punch

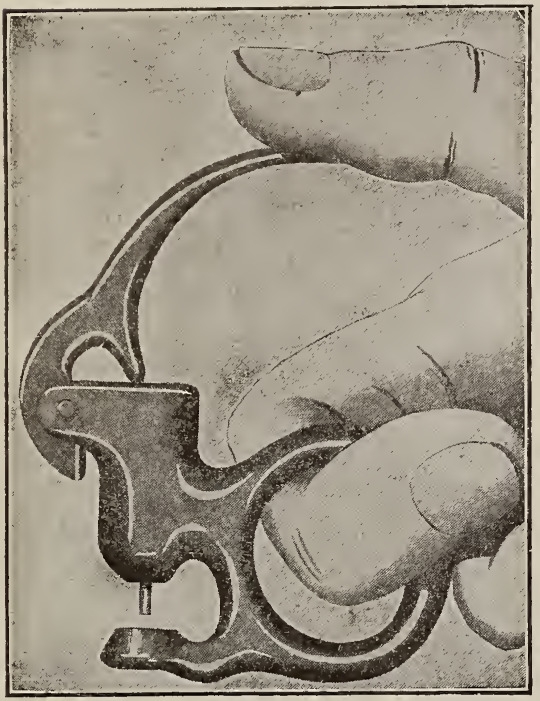

If you keep a record of your chicks, of the different breeds, hatches, strains, etc., there is no better, quicker or easier way than by using our latest invention, the Acme Spring Lever Poultry Punch for marking the web between the toes. Price, 35c postpaid.

\section{Drinking Fountains}
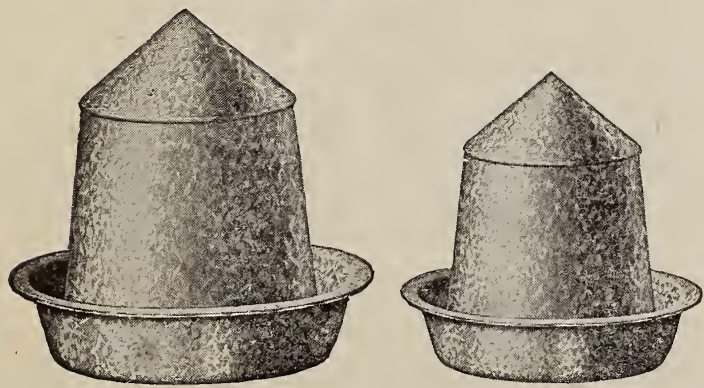

The Galvanized Iron Drinking Fountains embody every good feature of a down-to-date drinking fountain, and are believed to be the best in use. They have done much to supplant the old-style earthenware fountains which could not be thoroughly cleaned and purified. A fountain that cannot be easily and readily cleaned out, and in which water soon becomes sour, is highly obectionable. A fountain that will burst if the water in it freezes is also an annoyance and a source of loss. These fountains are easily filled, easily cleaned and kept clean. The interior of these fountains can, after being scalded, be exposed to the sun, and thus sweetened and kept wholesome. If placed in the shade in the summer time the water will placed in the shade in the summer time the water will 1 qt., 25c; 1/2 gal., 35c; 1 gal., 50c; 11/2 gal., 70c; 1 gal., $90 c$.
There is no doubt in the ninds of up-to-dute poultrymen as to the advantages of caponizing. The operation is very simple, and with a "Triumph Caponizing Set" any boy twelve years or age can perform it with safety and thorough. ness. Capons, as anyone knows, sell on the market as a chichs. The ether crowing, and at this time a better market is , is steadily producer in this field than any other. Now is the time to get into the caponizing business, and the first thing to start right is to buy a "Triumph Capouizing Set." No moreeffcient, simple or more easily operated set is being offered mistake byda mo mistake by selecting the Triumph set.

Set in plus -lined cloth RRICES

et in polished hardwood box cuse................\$3.00 Set in Japanned wood box $\ldots \ldots \ldots \ldots \ldots \ldots \ldots \ldots \ldots \ldots \ldots \ldots .275$ We pay transportation charges within the United States

Insect Powder Blowers

ASPINWALL-Excellent for blowing powder on vines and bushes. Price, \$1.2.

JUMBO-Price, 25c; postpaid, 35c.

DEFENDER-Price, 15c; postpaid, 25c.

Champion Leg Band

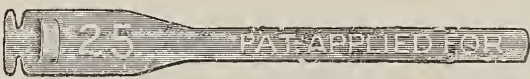

The oldest and most popular band on the market. This band is made in one piece in two sizes, adjustable to fit any fowl. They will stay where you put them. Held by double lock, it is impossible for them to lose off. Made of aluminum or copper in two sizes, large size for Asiatic class and turkeys; small size for Plymouth Rocks and all smaller breeds. Price, postpaid, 12, 15c; 25, 30c; 50, 50c; $100,80 \mathrm{c}$.

\section{Aluminum Pigeon Bands}

Pigeon Bands are seamless and open, with number.

PRICE, POSTPAID

Seamless, 12, 30c; 25, 60c; 50, \$1; 100, \$2.

Open, 12, 20c; 25c, 35c; 50, 60c; 100, \$1.

We are Headquarters for Poultry Wire.

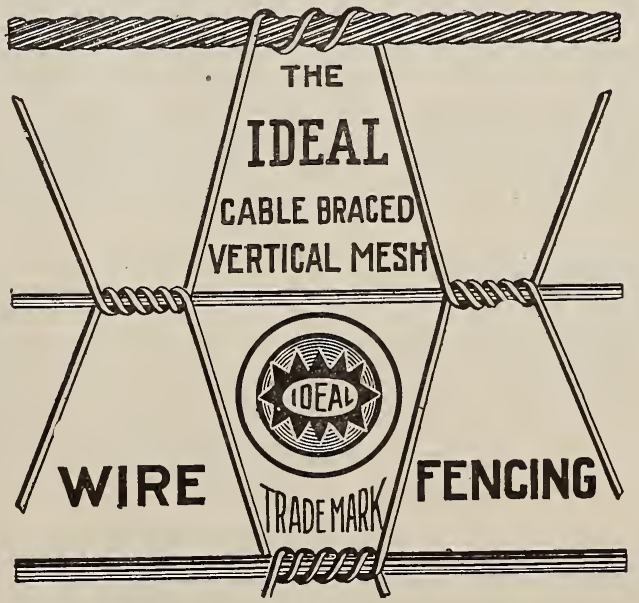

This cut shows the construction of the "Ideal" Poultry, Rabbit and Iawn Fencing. The "Ideal" combines strength, durability and neatness of appearance. It is flexible, and readily adjusts itself to uneven surfaces without buckling. Stretches in firm, straight lines without rail supports, and as compared with ordinary netting of same gauge wire, the "Ideal", in the complete fence is much cheaper, as fewer posts are used and no top or bottom rail is required to keep the fence from sagging or narowing together beto keep the fence from sagging or narowing together be"Ideal", Poultry and Rabbit Fence, which, combined with the great multiplicity of horizontal wires, makes it a very 


\section{Ideal Wire Fencing--Continued.}

strong, durable fence. Bear in mind that the bars in strong, durable fence. Bear in mind that the bars in
the "Ideal" fencing are only two inches apart. Put up in 10 -rod rolls.

\section{PRICES}

\section{PRICE TWO INCH MESH}

12 inch high, per roll, 10 rods........\$1.25, 5 roll lots, $\$ 1.10$ 24 inch high, per roll, 10 rods........ 2.25, 5 roll lots, $\mathbf{2 . 0 0}$ $\mathbf{3 6}$ inch high, per roll, 10 rods........ 3.16, 5 roll lots, $\mathbf{3 . 0 0}$ 48 inch high, per roll, 10 rods........ 4.15, 5 roll lots, $\mathbf{3 . 9 0}$ 60 inch high, per roll, 10 rods........ 5.25, 5 roll lots, 4.85 72 inch high, per roll, 10 rods....... 6.25, 5 roll lots, $\mathbf{5 . 8 5}$ ONE INCH MESH-150 FEET

18 inch high, per roll $\$ 3.75$

24 inch high, per roll 5.00 36 inch high, per roll 7.25

\section{MI. S. Poultry Fencing}

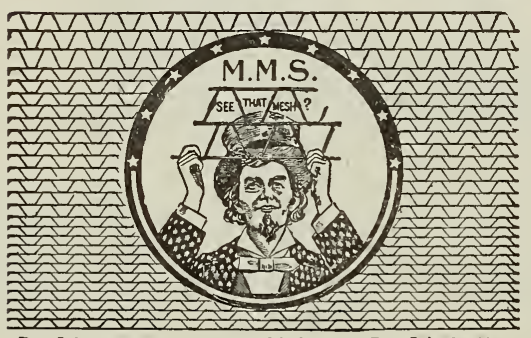

Pat. July 21, 1896.

Pat. July 6, 1897 .

The M. M. S. wire being only one inch apart at the bottom requires no board to prevent littel chicks passing through. Also saves buying expensive one inch mesh wire. 60 inches high, $\mathbf{1 6 0}$ feet long, per roll

$\$ 5.25$ 72 inches high, 160 feet long, per roll 6.00

\section{Pacoruco}

\section{The Durable Smooth Surface Roofing}

A slate colored, tough, leather-like material, made from a combination of wool-felt and the highest grade natural asphalt.

Not affected by water, acids, alkalies, gases or sudden changes in weather. Neat in appeararce and easy to lay. Will not dry out, become brittle and break.

Pacoruco Roofing does not contain coal tar, Texas or California residuum (alleged asphalt), stearin pitch or candle tar. It is composed of the highest grade natural candle tar. It is composed of the highest grade natural asphalt known. What is the composition of the "oids"' and "ites"?

Made in four weights and put up in rolls to cover 100 and 200 square feet.

$1 / 2$ ply, per 100 square feet.

1 ply, per 100 square feet.

$\$ 2.25$

$\mathbf{2}$ ply, per $\mathbf{1 0 0}$ square feet

$\mathbf{3 . 0 0}$

feet...............00

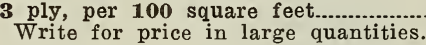

\section{CHURCH'S CHICK FEED}

\section{Means Profit for the Poultry Man}

If fed from the start you will have bright, healthy chicks, and if the chicks are given nothing else but green stuff and water you can raise 95 per cent of them to the age of six weeks at a cost of two cents each. Every one who has raised poultry knows that the critical time is then over. With this feed incubator chicks are a success. With the methods usually follewed there is too great a mortality among the young chicks the first six weeks. Good care and an exclusive Church Chick Food diet will reduce the mortality to the minimum.

\section{POULTRY FOODS}

\section{Church's Chick Feed}

The experience of poultry raisers is the same the world over. Everybody knows that the first few weeks is the critical time-that's when the distressing losses comelosses that are so severe that about one-half the people who engage in poultry raising are driven out of the business, the weak unused stomachs of newly hatched chicks cannot suddenly accustom themselve to the illy adapted, poorly balanced foods that are supplied. Unbalanced food means failure of digestion, and that means decrease of an already low temperature, chills, bowel troubles, "sleepy disease", and almost certain death. By 'using Church's Chick Food you can give the chicks just what nature intended they should have, a food composed of grains (cracked), small seeds, grit, bone, dried sweet meat (to take the place of insects and bugs), charcoal, etc., etc., mixed in the right proportion to produce a quick and profitable growth with. proportion to produce a quick and profitable growth with
out loss. You can raise so many more chicks by feeding out loss. You can raise so many more chicks by feeding
it, that it is the cheapest food you can buy. Price, 25 lbs., 85 ; 50 lbs., $\$ 1.60 ; 100$ lbs., $\$ 3.00$.

\section{Cut Alfalfa}

The value of some green food for fowls can hardly be overestimated. For a winter food we have found by experience that alfalfa is one of the best for this purpose. It contains more protein lime and mineral salts in soluble and digestive form that clover, and fowls relish it in either a green or dry state. For producing eggs in winter it has no equal. For little chicks it furnishes the element for growth, making bone, blood, muscle, feather and preventing disease. Price, 100 lbs., $\$ \mathbf{2 . 2 5}$.

\section{Granite Crystal Grit}

The sharpest and hardest grit known. Free from dust, is sharp, hard and clean. Rich in iron, silica, aluminum and mica, a health giving tonic. Viewed under the magnifying glass, it shows myriads of crystals clear as glass and sharp as a diamond. Each crystal has sharp edges which cut and grind, and grind and cut until the last minute particle is worn away. Thus it will last two or three times longer than any other grit, and is therefore cheaper. We ened not enlarge upon the value of grit for poultry. Every poultryman knows how necessary it i to poultry. Elfare. To obtain best results, grit must not only be sharp when eaten, but must remain sharp under the be sharp when eaten, but must remain sharp under the proves itself superior to all others, its hard texture and thousand-cornered crystals serving to sharpen each other while grinding the food for the digestive organs. Grit should be put in a small box tacked up in the hen house. Let the fowls eat all they want of it. In ordering please state whether you want chick size or poultry size. Price, state whether 1 lbs., $\$ 1.25$.
100

\section{Oyster Shell}

\section{Eastern Oyster Shell Washed and Screened.}

Every poultry house or yard should have a pan or box filled with crushed shells, so that the fowls can have access to them at all times. Oyster shells prevent soft shell eggs, makes the egg shells strong enough to carry without breaking and makes eggs larger and heavier. If you have been using Puget Sound Shell, try a sack from us. There is 20 per cent. less waste. Price, 10 lbs., $25 \mathrm{c} ; 100$ lbs., $\$ \mathbf{1 . 7 5}$

\section{Granulated Bone}

Many poultry men prefer granulated bone to fresh or green bone. Fresh or green bone contains 53 per cent. of moisture and 12 per cent. of grease, so that when a poultry man buys fresh bones he pays for 65 pounds of useless materials in every 100 pounds he buys. Granulated Bone, materials in every 100 pounds he buys. Granulated Bone, while more expensive as a rule than green bone, fully
makes up for the difference by its concentrated value. It is made from fresh green bones with the moisture and grease taken out, leaving nothing but the phosphate of lime and nitrogen. Price, 10 lbs., 30c; 100 lbs., \$2.50.

\section{Armour's Meat Meal}

Armour's Meat Meal contains from 50 to 65 per cent. of protein, 10 to 12 per cent of fat and less than 5 per cent. of ash. Made fro mhearts, livers, meat scraps and cracklings from United States government inspected ani mals. Pure, clean, sweet and wholesome. Will keep indefinitely if stored in a dry place. Price, 100 lbs., \$3.S5. 
(POULTRY FOUDS-Continued)

\section{Armour's Beef Scraps}

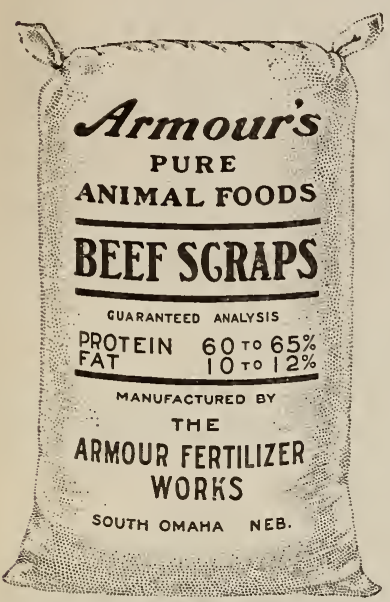

The object in buying Beef Scraps or Meat Neal is to obtain the largest anount of di-
gestible protein sible, as protein is what you are in quest of to balance your ordinary Farm Foods and grains. Armour's Beef sicraps Armour's Beef scraps per cent. of protein, 10 to 12 per cent. of fat aud less than 5 per cent. of ash.

The guarantee on protein gives you an approximate value of the feed, but the percentage of ash contained tells rou whether you are buying pure meat product or not.. Price, 100

\section{Dried Blood Meal}

One great reason why hens do not lay in winter is because they are not supplied the proper elements to produce the rolk of an egg. This can be remedied by the use of Dried Blood Meal or Beef Scraps. Blood Meal is the highest concentrated form of animal food and prepared so as to include all the elements of the so-called Red tlbumen. Use one tablespoonful to six hens once a day. Price, 5 lbs. 25c; 100 lbs., \$3.00.

\section{Charcoal}

Our Charcoal is granulated, prepared especially for poultry; no dust; a good thing for bowel trouble, sour crop and indigestion; a health preserver. Price, lb., 10c; $\mathbf{3}$ lbs., 25c; 100 lbs., $\$ 5.50$

\section{Church's Balanced Ration}

This is a complete food ground and ready to mix with water, hot or cold, according to the season. It contains all the ingredients necessary to promote quick growth, to produce eggs and to keep the birds in a good condition, summer and winter. Random and haphazard feeding is no longer profitable. Try this food and be convinced. We have thoroughly studied the subject of food for fowls and know this mash will give you the desired results. It is no more trouble to feed than a bucket of ordinary food, which is often as good as wasted, as the results are not generally often as good as wasted, as the results are not generally
satisfactory. To be successful you should make every pound of feed show results. Church's Balanced Ration costs only a little more than wheat or corn and is of twice the value. Try it. Price, $85 \mathrm{lb}$. sack, $\$ 1.50$.

\section{Church's Scratch Food}

This is a balanced ration, all grain poultry food, composed of the choicest grain and other ingredients. In the first place, our factory is situated where we can get the best of Northern-grown wheat, to this is added sunflower, corn, oats, peas, kaffir, rape, millet, oyster sheils and grit in jut the proportion that sereral rears of experience has demonstrated is right. Every practical poultry man will readily concede that such a diversity of the most valuable feeds will put hens in just the right shape for laying. Price, per 100 lbs., \$2.00.

\section{Millet}

This is a good scratch food. Place it in some chaff or litter and make your hens work for it. Price, 10 lbs., 50c; 100 lbs., \$3.25.

\section{Feed Grains}

We keep in stock for feed WHEAT, CORN BARLEY, OATS, BRAN SHORTS, etc.. As above feeds fluctuate so in value we do not quote prices, but will be pleased to do so upon application.

\section{Ground Flax Seed}

Good for chickens or stock. Price, lb., 5c; $100 \mathrm{lbs}$., market price.

\section{Oil IVIeal}

Price, 8 lbs., 25c; 100 lbs., market price.

\section{Kaffir Corn}

Fine for chicks five to six weeks old. Price, $10 \mathrm{lbs}$. 40c; 100 lbs., \$2.50.

\section{Pratt's Poultry Regulator}

This is the original Poultry Regulator, in use by the most succesful poultry-raisers everywhere. It is entirely different from Pratt's Animal Regulator. It is composed of raluable imported roots, herbs and barks so blended as to make a perfect regulator, tonic and stimulant, suited to the constitution of the poultry.

Pratt's Ponltry Regulator overcomes the difficulties met by every poultryman by regulating the blood, bowels and digestive organs of all fowls. Thus it keeps the birds in robust health, produces good rich blood, healthy fat, sturdy muscles, strong bones, red combs and wattles, brilliant feathers and fertile eggs. It stands unrivaled as an eggproducer, and when regularly used, the hens lay through. out the year. Price, 2.5c, 50c, \$1.00 and \$1.25 packages.

\section{Pratt's Lice Killer (Powdered Form)}

is entirely unlike any other preparation of the kind on the market today. It is non-poisonous and non-explosive, and being stronger, has greater disinfecting qualities.

It quickly and thoroughly kills all lice on little chicks, big chicks, sitting hens, and incubator chicks - with it nests, litter and dust bath are sprinkled. It rids horses, cattle, hogs, dogs, and cats of lice, and destroys ticks on sheep. It destroys insects and bugs that ruin shrubbery, deodorizer and disinfectant, and should be used in all poultry houses, barns, stables and dwellings. It also drires out moths and bugs from closets, furniture, car pets and clothing. Refuse all imitations, and insist on getting the genuine Pratts Lice Killer. One box will pay its cost many times over. Package, 25c; postpaid, $40 \mathrm{c}$.

\section{Pratt's Liquid Lice Killer}

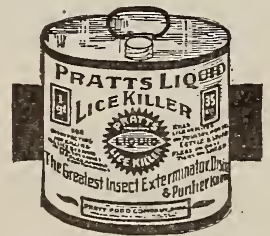

is the strongest liquid preparation on the market for the destruction of poultry lice and lice on horses, cattle, cows and hogs; ticks on sheep and flees on cats and dogs. It is invaluable for houehold use, for cleaning and disinfecting drains, sinks, slop pails, cellars, stables and outhouses.

Pratts Liquid Lice Killer is not only the surest, quickest and most effective but also the cheapest.

Sold in $35 \mathrm{c}$ and $\$ 1.00$ cans.

\section{Pratt's Bag Ointment}

is especially raluable for healing "caked udder" in cows, caused by injuries, scratches, blows or kicks, or from being over-distended with milk. If such troubles are not attended to at once, part, or all, of the udder may be destroyed.

Pratts Bag Ointment reduces the inflammation and promptly effects a cure. Sold in $\mathbf{2 5 c}$ boxes, postpaid $\mathbf{3 5 c}$.

\section{Pratt's Worm Powder}

is a special preparation for the destruction of all kinds of worms in horses, cows, hogs and sheep. It is purely vegetable, has a strong tonic effect that builds and helps the animal to regain strength, and is unquestion-

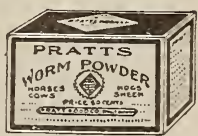
ably and quickest, surest and most thorough worm-destroyer procurable. Sold in 50c boxes; postpaid, 65 c.

\section{Lice Powders}

IILIY'S IICE POWDER-Hen lice weaken the fowls and thus make them an easy prey to disease. Keep the lice off, and you will not only get more eggs, but vour hens will be less liable to contract disease of any kind. Iilly's Lice Powder is especially useful on little chicks and setting hens. All well ordered poultry houses should have both lice powder and liquid lice killer to effectually prevent both lice powder and liquid
lice. Sold in cartons, 25c.

BUHACH-Per oz., 10c; 1/4 lb., 30c; lb., $\$ 1.00$

PERSIAN INSECT POWDER-Ib., 50c.

SKIDOO INSECT POWDER-It is death to insects but harmless to the animal or human. This powder will kil? any kind of insects on animals, fowls or humans, and has no odor or bad effect. Price, 50c. 


\section{Church's Best Lice Killer}

Destroys lice, mice, fleas and all kind of vermin. Is applied with a paint brush or sprayer to floors, roosts, nests and to cracks in the wall. It kills lice by its fumes. It penetrates every crack and crevice in the flooring and the penetrates every crack and crevice in the liooring and the kinds of vermin. Church's Best Lice Killer is the best and strongest lice killer known. It will do more work for less money than any other similar preparation now on the market. It does not contain kerosene or other dilutents. Each gallon is equal to from two to five gallons of other paints, washes or dip. The boxes in which you are going to put sitting hens, and the brooders in which you are going to keep your chicks, should be painted with Church's Best Lice Killer several days before they are used. Do not confine your chicks with this Lice Killer, except for a short time, and with plenty of ventilation. It is very pow erful and should not be applied direct to the skin as it will blister and remove the feathers. Remember that it is easier to keep the lice down than it is to get rid of them after they have once thoroughly infested your hen-house and its surroundings. Put up in quart cans, 3ac; gal. $\$ 1.00$.

\section{Rex Lime and Sulphur Solution}

What Poultry Raisers Have Been Looking For.

The most marvelous poultry lice and mite killer of the age is Rex Lime and Sulphur Solution, and non-poisonous. Lice and inites kill poultry profits-Rex and non-poisonous. cocks to grow and hens to lay-a profit getter, makes the disinfects, kills vermin lice lay-a profit getter, thoroughly Keeps the poultry healthy, and mites as nothing else will Keeps the poultry healthy, protects against disease from lice and mite troubles, ideal and is sprayed for one-tenth the cost of any product for like purposes. Vermin, lice and mites thrive in oil. Spray the ground as well as the roost and building. The little cost allows spraying once a week; this means a big earning power. Spraying is just as necessary during the winter months as during the warm weather. Dilute 1 to 5 , or in other words, add 5 galions of water to one gallon of solution. Price, per gal.,
$\mathbf{7 5 c} \mathbf{5}$ gals., $\mathbf{\$ 2 . 5 0}$.

\section{Tobacco Dust}

For use in dust baths or nests. A cheap and effective exterminator of lice. Price per lb., 10c; postpaid, 25c.

\section{Poultry and Stock Remedies, Etc.}

\section{SKIDDOO REMEDIES}

Compressed Tablets for live stock are made from the alkaloids and the active principle of the drugs and contain no ashes, sawdust, chop feed or bran. They are just as good when ten years old a when ten days old, and comply wi.h all pure drug laws.

\section{Skiddoo Condition Tablets}

If your live stock is out of condition use Skiddoo Condition Tablets. It will pay to use these tablets two or three times a year for all your stock. It will tone up the system, regulate the natural secretions and place the animal in regulate the natural secretions and place the animal in 50c and $\$ 1.00$ per box.

\section{Skiddoo Heave Tablets}

If your horses have heaves, give them Skiddoo Heave Tablets. They will remove the cause and cure the animal. Price, 50c and $\$ 1.00$ per box.

\section{Skiddoo Worm Tablets}

If your animal has worms of any kind, give Skiddoo Worm Tablets; they are death to worms. Price, 50c and $\$ 1.00$ per box.

\section{Skiddoo Fever Tablets}

If your animal has fever, give Skiddoo Fever Tablets; they will kill the germ and cure your animal.

\section{Skiddoo Distemper Tablets}

If your animal has distemper, give Skiddoo Distemper Tablets. Price, 50c and $\$ 1.00$ per box.

\section{Skiddoo Colic Tablets}

If your animal has colic, give Skiddoo Colic Tablets they will remove the cause and cure your animal. Price, 50c and $\$ 1.00$ per box.

\section{Skiddoo Cathartic Tablets}

If your animal is costive, give Skiddoo Cathartic Tablets. They will start the natural secretions and regulate the bowels. Price, 50c and \$1.00 per box.

\section{Skiddoo Hog Cholera Tablets}

If your swine have cholera, give Skiddoo Hog Cholera Tablets. They will kill the germ and cure your swine. You should use Skiddoo Hog Cholera Tablets whether your swine has cholera or not. Their antiseptic effect will aid in preventing cholera. Price, 50c and $\$ \mathbf{1 . 0 0}$ per bottle.

\section{Skiddoo Chicken Cholera Tablets}

If your fowls have cholera or other ailments, use Skiddoo Chicken Cholera Tablets. They will kill the germs and cure your fowls. You should use Skiddoo Chicekn Cholera Tablets freely with your fowls. Their antiseptic properties will aid in preventing disease and keep them healthy. Price, $50 \mathrm{c}$ and $\$ 1.00$ per box.

\section{Skiddoo Pink Eye Tablets}

If your animal has pink eye or other disease of the eyes give Skiddoo Pink Eye Tablets. They will remove the cause and cure the eyes. Price, 50c and $\$ 1.00$ per box.

\section{Skiddoo Lice Powder}

If your animals are lousy, use Skiddoo Louse Powder. It is death to insects but harmless to the animal or human. This powder will kill any kind of insects on animals, fowls or humans, and has no odor or bad effect. Price, 50c and $\$ 1.00$ per box.

\section{Skiddoo Blister. Tablets.}

If your animal needs a blister, use Skiddoo Tablet Paste. This is the finest blister ever put upon the market. Price,
50c and \$1.0 per box.

\section{Skiddoo Barb Wire Liniment}

If your animal gets cut on barb wire or otherwise, has rheumatism, stiffness or other trouble requiring a liniment, use Skiddoo Barb Wire Liniment. Price, 50c and

\section{Skiddoo Spavin Remedy.} If your animal has spavin, use Skiddoo Spavin cure.
Price, 50c and $\$ \mathbf{1 . 0 0}$ per bottle.

\section{Skiddoo Kidney Tablets}

If your animal has kidney trouble of any kind, use Skiddoo Kidney Tablets. They. will correct the functions of the kidneys and cure your animal. Price, 50c and $\$ \mathbf{1 . 0 0}$
per bottle.

\section{Lilly's Poultry Tonic}

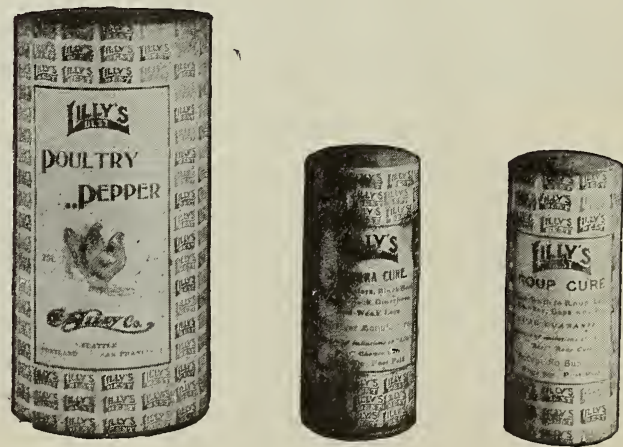

This is an all around reliable, medicated food and tonic for poultry; prepared from ground seeds, roots, herbs and 


\section{Poultry and Stock Remedies, tic.}

drugs; these are all carefully selected and blended in the proportion that make it most nutritious and healthy food for poultry. It is fed as an appetizer. a toric ard as a preventive of disease, and by thus getting the fowls in prime shape, assists in egg production. It is a great stimulator to growth, tones up the digestive organs, purifies the blood, tones up the digestive organs, purifies the blood, and keeps the whole system in working order, thus warding off disease, preventing roup, canker and a dozen other ing off disease, preventing roup, canker and a dozen other try Tonic mixed with a food such as Church's Balanced Ration will prove a great help in keeping digestive organs in a healthy and vigorous condition. It is economical, as it enables poultry to more thoroughly digest and make use of their food. It not only stimulates egg production, but is also valuable in the case of fattening heas, enabling them to consume and properly digest a larger amount of grain feed and make a gain in weight much more rapid. Lilly's feed and make a gain in weight much more rapid. Lilly's Small package, 25c; large package, 50c; pails, \$2.50.

\section{Lilly's Stock Remedy}

Gives to horses, hogs and sheep new life and also strength. Keeps their blood pure and aid digestion. Saves money on the amount of grain fed. Makes the young colts grow rapidly and sturdy. Gives a glossy coat and bright eyes. Fattens the hogs in 30 to 90 days less time. There is no injurious ingredient in Lilly
rations will positively do no harm.

Two tablespoonfuls a day will keep a horse in the best condition and reduce his grain feed. Horses that need "toning up", require a domble dose. Hogs eat it freely and develop wonderfully. Sheep thrive on it. The cost of Lilly's Stock Food is nothing compared to the results you will obtain. Sold in $25 \mathrm{c}$ and $\mathbf{5 0 c}$ packages; $\mathbf{2 5} .1 \mathrm{~b}$. pails, $\$ 2.50 ; 100-1 b$. barrels, \$8.00.

\section{Lilly's Cow Conditioner-For Cows Only}

Adapted to the special needs of the cow. It prevents such ailments as abortion, barrenness milk fever, retained after birth and scours, etc., and keeps the cow in a perfect physi cal condition. Reduces to almost nothing a large percentage of the undigested food which is a needless waste and from which the cow receives absolutely nothing of benefit. If Lilly's Cow Conditioner does not pay you twice over for your purchase more than the usuel way of fattening, we will refund your money.

Every package is sold on a positive guaranteed basis. For calves it is a wonderful strength giver. Remember, it is not what your cows eat, but what they digest, that makes them fat and profitable. Sold in $25 \mathrm{c}$ and 50c packages; 25-1b. pails, \$2.50; 100-ib. karrels, \$\$.03.

\section{Conkey's Roup Remedy}

Many poultry men make the mistake of waiting until their. flocks contract a cold, or are down with the Roup, before ordering. They are taking big chances, as Roup develops quickly, spreads through the flock rapidly, and death may claim a lareg number before the remedy can be obtained. Al. ways keep a box of CONKEY'S ROUP REMEDY on hand. A little in the drinking water, occasionally, will prevent this
call in the drinking water, oc-

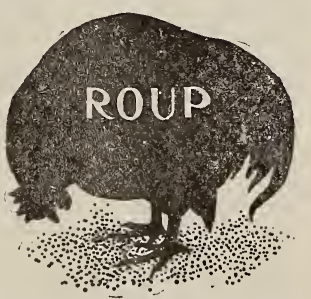
disease and will serve as an excellent tonic when the vitality
of your fowls is impaired. Prices, 50c and $\$ \mathbf{1 . 0 0}$, postpaid. Enough to make 25 and 75 gallons of medicine and allow frequent freshening.

\section{Conkey's Cape Remedy}

A reliable remedy for this terrible enemy of little chicks. Price, 50c; postpaid, 60c.

\section{Lilly's Cholera Remedy}

For cholera, black head, diarrhoea and ewak legs. It will effect a permanent cure in from one to three weeks, and is especially to be recommended is especially to be recommended
for pigeons. Price, 50c, postpaid.

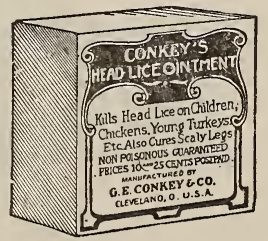

\section{Lilly's Poultry Pepper}

This is a pure, strong cayenne pepper. Put up in onepound sealed cartons. It is always the same, can always be depended upon and answers the demand for a reliable poultry pepper. Sold only in cartons, 2.,c.

\section{Thedford's Black-Draught}

Nearly every family owns animals or fowls for pleasure or profit, and should have Black-Draught Stock and Poultry Medicine to keep them healthy. It is used very extensively among prominent breeders of horses, mules, cattle, hogs, sheep, turkeys, chickens and dogs to prevent and to cure all the common diseases infecting flocks and herds. It has all the good qualities of the famous Thedford's Black. Draught, with other ingredients added to make it palatable for stock. Price, 25c; postpaid, $40 \mathrm{c}$.

\section{Kow Kure}

Kow Kure is the only known preventive of abortion, barrneness, retained after-birth, scours and other ills to which the cow is subject. It is used with unfailing success in thousands of the best dairies in America. It is not a stock food, but a medicine. Large can, \$1.00; small can, 50c.

\section{Copperas}

1 small piece placed in drinking water is a good tonic for shickens. Per 1b., 10c.

\section{Palmer's Squirrel and Gopher Poison}

The best and cheapest poison ever compounded for the speedy destruction of squirrels, gophers, etc. Price, per can, 25 c.

\section{Peerless Gopher Exterminator}

This is sure death to gophers and squirrels and will soon clean out the pests. After being placed in the burrows, the odor remains for a long time preventing other animals from occupying the holes. Price, per can, $75 \mathrm{c}$.

\section{Fly Knocker}

A sure and effective remedy against fiies and mosquitoes. By the use of Fly Knocker during hot weather your cows will give one-third more milk; your horses will rest better and work during working hours on two-thirds the feed they now require, and will be free from vermin of all kinds. Fly Knocker is the greatest cure for barb wire injuries ever placed on the market. Prevents inflammation and fly blows and causes wounds to heal very rapidly. Also cures cuts, scratches, burns, scalds, flesh wounds, old sores, etc. Price, qt., 50c; $1 / 2$ gal., 90c; gal., \$1.50.

\section{FERTILTZERS}

It pays to use Commercial Fertilizers because the cost of preparing, planting, cultivating and harvesting a full crop is no more than that of a half crop. Becanse the crop that is healthy and vigorous is not apt to be troubled with insects, scale and other pests. Because on a crop where Fertilizers have been used the product is not only greater in weight, but is much better in quality and will sell for more money per bushel or hundredweight.

\section{Dried Blood}

This is by far the finest of the numerous nitrogenous products furnished by the slaughter houses. It is very rich in nitrogen, often containing almost as much nitrate of soda, the chemical analysis showing from 10 to 15 per cent. nitrogen. It is the richest organic nitrogenous manure. Price, per 100 lbs., \$2.75.

\section{Bone IMeal}

The analysis of bone meal shows from 2 to 4 per cent. nitrogen and 20 to 30 per cent. phosphoric acid, also phosphate of lime and organic matter. For slow-growing crops, such as orchards and permanent pastures, and with a view to the improvement of the soil, bone meal is an ideal source of phosphoric acid and nitrogen. Price, \$2.50 per $100 \mathrm{lbs}$.

\section{Tankage}

This is a slaughter house product composed of meat scraps, hoofs, tendon, bone, etc. These are ground into a fine meal, having but little odor and serves as a useful carrier of both nitrogen and phosphoric acid. The analysis shows 5 to 7 per cent. nitrogen and 12 to 15 per cent. phosphoric acid. Price, \$1.75 per 100 lbs.; \$2S.00 per ton.

NITRATE OF SODA-Price, 6c lb.; per $100 \mathrm{lbs}$, \$4.50.

SUIPHATE OF POTA.SH-Price, 6c lb.; 100 lbs., \$4.50. GYPSUM-Price, 2c lb.; per 100 lbs., $\$ 1.00$.

BOWKER'S PLANT FOOD-A first class fertilizer for house plants. Pkg., 25c. 


\section{Spray Pumps and Material}

\section{The IIyers Cog Gear Hydraulic Spray Pump, Double Acting}

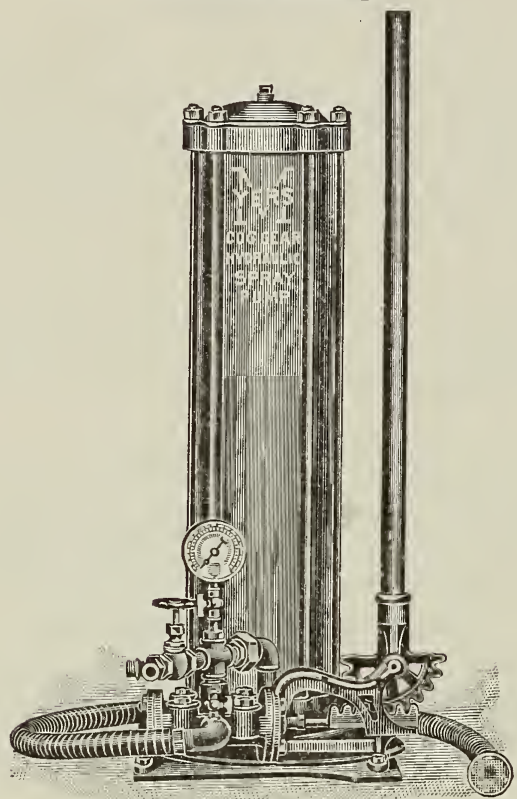

H'igure above represents the Myers Cog Gear Hydraulic Spray Pump. It has an air chamber 8 inches in diameter by 36 inches in height; mounted on one base in connection by 36 inches in height; mounted on one base in connection brass lined cylinder fitted with brass seats and brass valves, each of which can be removed independently withou disturbing any of the other parts of the pump, and connected direct to the air chamber, the large capacity of which enables the pump to be used with two or four leads of hose. Has compression brass shut-off in the discharge and is furnished with 200 pound pressure gauge.

One of the important features of this pump is the ratchet handle connection, by means of which the leverage is in creased over 40 per cent, making the pump easy to operate under heavy pressure.

The piston is brass, packed with hemp, thus permitting the use of either hot or cold mixtures. It is especially adapted for spraying large orchards. It is furnished as specified in list.

\section{PRICES.}

Pump with pressure gauge and 6 feet of 1 inch wire bound suction hose

Pump with pressure gauge, 6 feet suction hose, two nozzles and two 8 fout pipe extensions, with

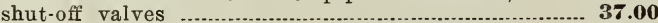

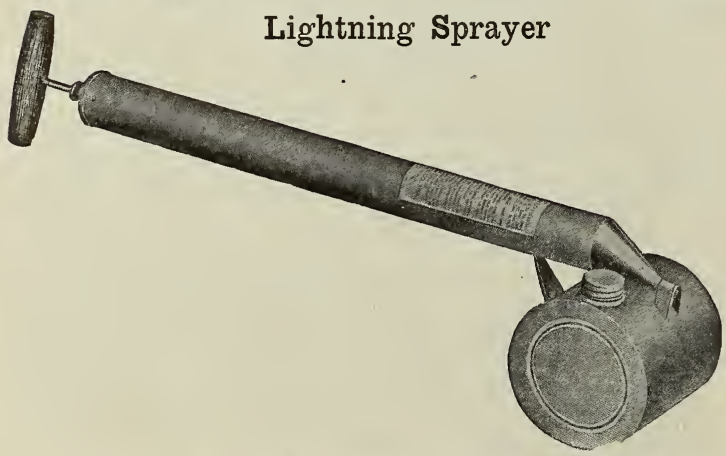

We have this in either single or double tube. Price, (60c

\section{The "Simplex" Barrel Spray Pump}

A Popular Orchard Sprayer, With Mechanical Agitator and Brass Working Parts.

Thousands of these pumps have been sold in all parts of the world during the past ten years, and it remains with the dealers one of the most popular styles manufactured. It may be used on the side or end of barrel, and we furnish with each pump a wooden base, upon which the pump rests, so that all that is necessary to set up the outfit is to cut a $10 \times 10$ inch opening in the top of the barrel, place in the pump, screw it down, and the sprayer is ready to use. We send them out completely adjusted. The air chamber is large and insures a constant stream.

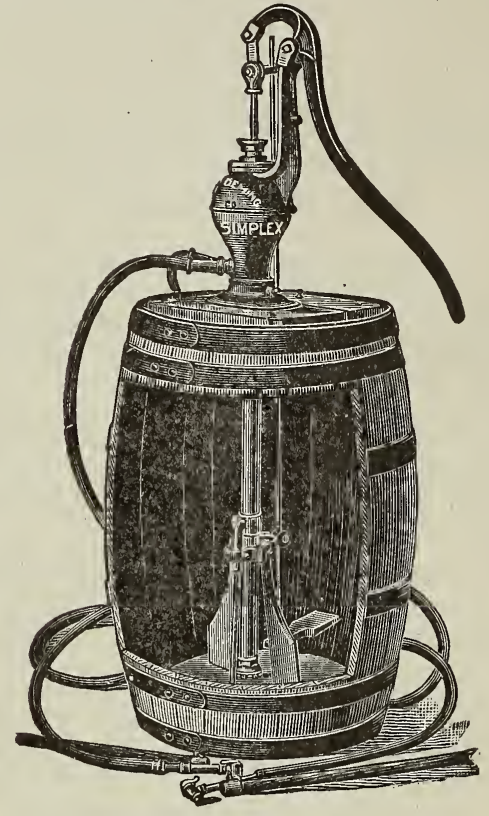

Simplex Pump.

THE MECHANICAL AGITATOR-Without an efficient agitator a barrel pump for orchard spraying is worse than useiess in the application of the Bordeaux mixture and Paris Green. These two mixtures sink to the bottom of the barrel, and in order that the spraying may be uniform, a constant churning of the liquid is necessary. This can only
be obtained by the use of the agitator here shown. With our agitator, uniform results are obtained. The working parts are made of brass, the cylinder being brass lined, the piston rod cased, and the plunger and valve solid brass. The discharge is provided with a Y connection, a tight cap being furnished for use in case but one section of hose is used. Three-way stop cock fits this pump, and customers preferring this stop cock on the discharge can order it separately at any time.

\section{PRICE LIST.}

Pump only, with $\mathrm{Y}$ connection

Pump as above, with $12 \frac{1}{2} \mathrm{ft}$. of $1 / 2$-in. hose nozzle

Pump as above, with two $121 / 2 \mathrm{ft}$. section of $1 / 2$-inch $\$ 9.50$ 12.50 hose, nozzles and conection In Ordering Pump Outfits, State which Nozzle You Prefer

\section{Spray Mose}

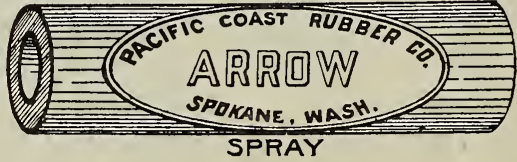

Best 7 ply 1/2 inch discharge hose, price, per foot Best 5 ply $1 / 2$-inch discharge hose, price, per foot 


\section{SPRAY PUIMPS, ETC.-Continued}

\section{The Century Sprayer}

With submerged brass cylinder, brass ball valves and "Everlasting", plunger packing. For durability, ease of

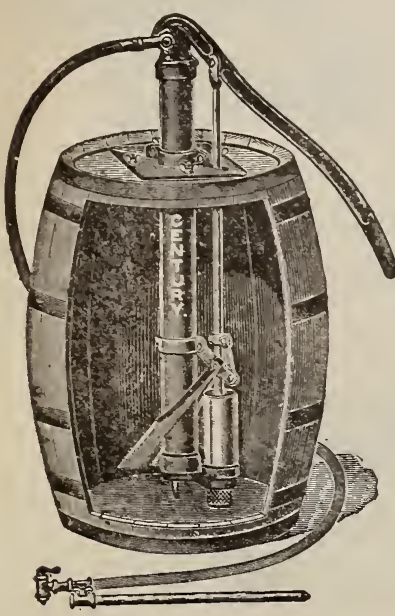

For durabil operation, free water ways and positive action
generally, this pump stands in the front rank. The automatic agitator is the only one that thoroughly agitates the liquid. These special features give the Century pump the lead tury pump the lead sprayers. The capacity is sufficient for all ordinary purposes. Length of stroke is 5 inches and diameter of cylinder $2 \frac{1}{4}$ inches. The air chamber is large, and the dis charge is fitted with "Yarge is fitted with a $1 / 2$-inch hose. The pump is furnished regularly with a cast base with hook bolts to fasten to the end of barrel. This base has a large hole with cover for filling the with cover for filling the
barrel. It is the easiest of any pump made to mount on barrel.

Fig. 645. Century Sprayer only $\$ 14.00$ Fig. 645. Outfit $A$, same as above with $121 / 2-f t$

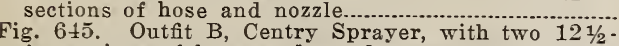
ft. sections of hose, and nozzles 17.00 Junior No. 5

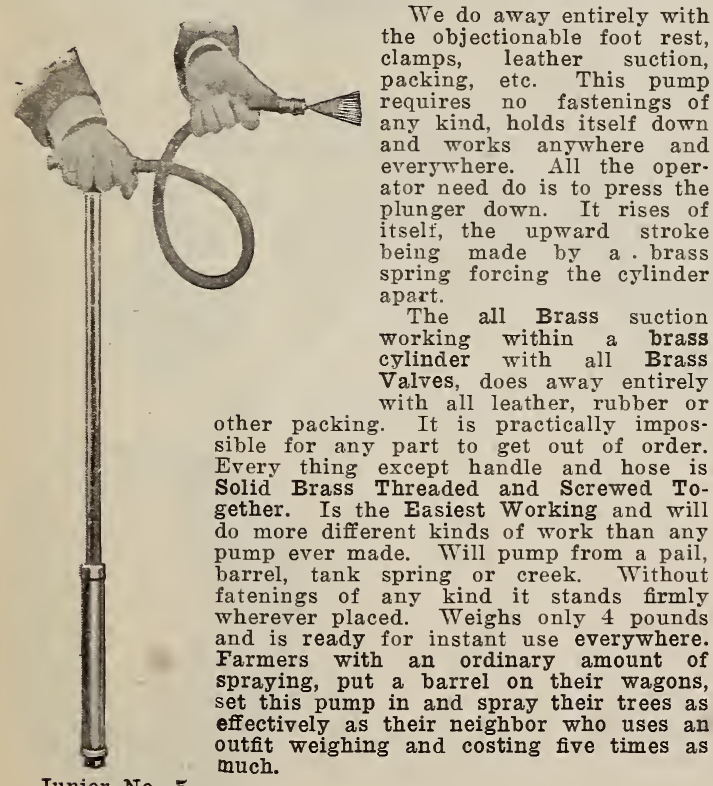

Junior No. 5

Will throw three sizes of solid continuous streams and two sizes of fine round spray. Has automatic mixer to keep solution stirred, pleases everybody and will last a lifetime. Price, \$3.00.

\section{For Additional Spray Dumbs See Page 42}

\section{"LIGHTNING" COIMPRESSED AIR SPRAYER.}

The new Lightning Co m p r e s s ed Air Sprayer is made of heavy galvanized iron or brass, holding or brass, holding is provided with a brass safety valve to prevent overpressure, an adjustable shoulder strap with a snap at strap with a snap at each end, three best hose and our automatic brass shut-off nozzle, which is held in one hand and worked at the will of the operator, by simply press. ing the thumb a trifle, letting out an instantaneous spray, and by releasing tri thumb the nozzle shuts itself off automatically, therefore the operator at all times has the spray under perfect control and there are no liquids wasted. It is also provided with our patent brass strainer, as shown in cut, so that no

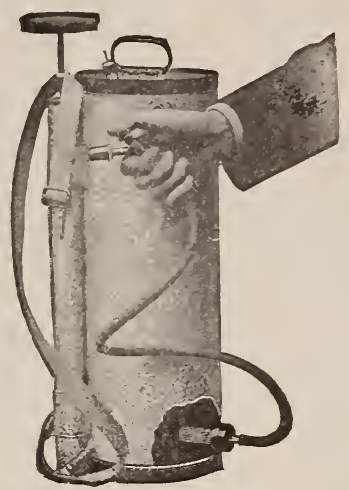

Patented

Holds Four Gallons.

Packed One in Case. sediments can pass

through the hose or nozzle, which prevents clogging.

The tank is double seamed, which makes it exertmely strong and durable. The air inlet valve on this machine, that is, the valve which the air passes through from the pump into the tank, is made entirely of brass. This is a double valve and so constructed that after the air is pumped into the tank there is no danger of this valve leaking and the strong ingredients used in the machines will have will have no effect on this valve whatever. After the small nut at the bottom of the pump with the fingers and small nut at the bottom of the pump with the fingers and
the valve is locked. This is a big improvement over all Compressed Air Sprayers, as heretofore there has been more or less trouble with the air inlet valves.

There is no labor required to operate this machine: simply fill the tank about two-thirds full of liquid, pump in a few strokes of air and the sprayer will do the rest.

in a few strokes of air and the sprayer will do the rest. foot lengths with connections, used for spraying trees. Full instructions on each machine.

Price, with galvanized steel body.......................................\$5.50

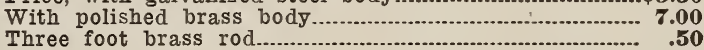

\section{The Success Bucket Spray Pump}

All Brass Working Parts, with Indestructible Bronzo Valves, Malleable Iron Combination Foot-Rest.

Florists, gardeners fruit growers and farmers who wish a durable, convenient spray pump at a low cost can find nothing better. This outfit is a most excellent one for ordinary use in gardens, vineyards and orchards; for washing windows and buggies and for the application of whitewash. The pump has a large air chamber and is double-acting, throwing a continuous stream either solid or in fine spray. It is provided with Bordeau nozzle and four feet of discharge hose. Price, \$4.50.

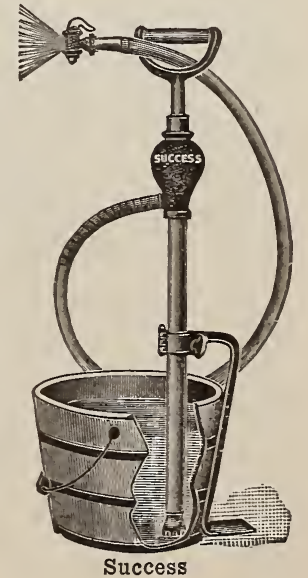




\section{Spraying Extras}

\section{Bean Double Norzle}

Two Sprays in One Nozzle.

This nozzle was invented and perfected to meet the demand for a "two-spray" nozzle. One side gives a broad, fine fan-shaped spray and throws as much or as as much as little liquid as desired, and spray.

The latter spray will reach the tops of trees which with other nozzles are left untouched. It will also throw a solid stream or shut off altogether. After the spray is adjusted to suit, it will be held in that position if the little set position if the little set
screw is tightened. Price, each in a neat box, 90c.

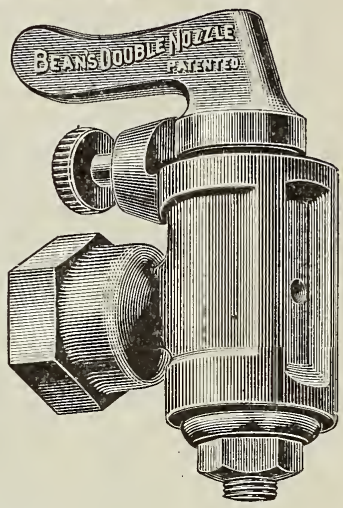

\section{Bean Nozzle}

The Old Standby for Whitewashing.

The nozzle throws a fine spray or a solid stream. It is particularly recommended for whitewashing and for washing buggies. Thousands of these nozzles are now in use and giving the best of satisfaction. To clean when clogged, turn the thumb screw straight out for an instant.

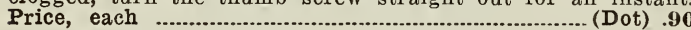

\section{Bean Best}

"The Unequaled Cyclone Nozzle."

Throws a fine cir. cular spray a loug distance.

Beans Best is a marked improvement on our Cyclone Long Distance Nozzle and furnishes a perfect spray. There are no parts to catch on the 列 furnished with each nozzle.

To clean, it is only necessary to jab the end against a tree, which forces the cap back onto a pin and opens the hole. The pressure from the pump instantly forces cap back to position.

Price, with two caps

Extra caps, each

(Den) .90

\section{Bean Clipper Nozzle}

Throws the most perfect, flat, fan-shaped spray. It prevents wasting of the spray and drippage.

1. The spraying lips are so shaped that all parts of the spray travel the same distance on the lip, thus meeting the same resistance and so carry just as far after leaving the nozzle. after leaving the nozzle. Hence

2. Any drops naturally fall into the notches on either side of the spraying lips, where they are instantly caught up by the stantly caught up by the little drippage. It throws either a fan-shaped spray, a long distance sray of a solid stream; can be shut off altogether and has the same patent adjuster.

as the Bean Double

Price, each, in neat box

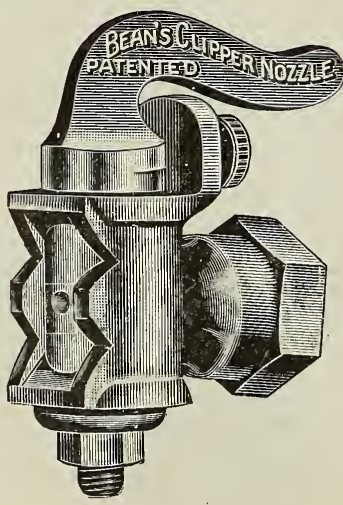

(Dell)

\section{Bean Vermorel Nozzle}

The Bean Vermorel Nozzle throws a beautiful, misty, circular spray.

All trouble caused by clogging in the bend is avoided by having the stem detachable. This also allows the nozzle to be turned to any angle desired.

There are no cum. bersome projections

to catch in the

limbs, and the nozzle is as small and compact as possible. This nozzle has a steel needle point for cleansing and an extra one of our long wearing caps with a larger hole is furnished with each nozzle.

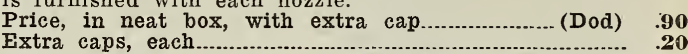

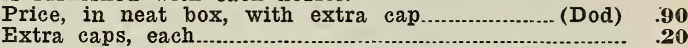
Extra caps, each
Your choice of any of these nozzles when ordering a pump.

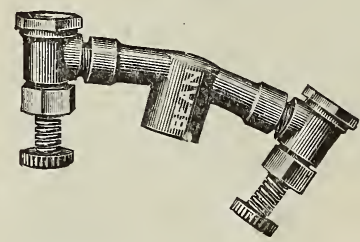

(Dire) $\$ 1.75$

Double Vermorel, each

\section{Bean Spray Hose Couplings}

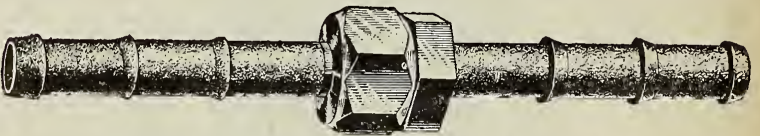

With hexagon nuts and double length shank, so will not pull or blow out.

Price per pair...

(Doff) $\quad .55$

Female half only

(Doge)

\section{Bean Spray Cut-0ff}

This $1 / 4$-inch shut-off is for use on spray rods in place of globe valves. Shuts liquid off instantly, saving time and material. Now used on all our bamboo extensions. Can be put on any rod. Price, each

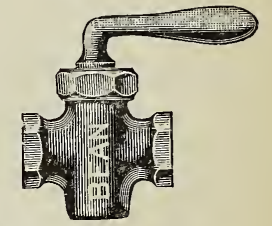

\section{Spray Hose Clamps}

Two of these clamps can be used on our long shank couplings and mender.

We carry them in stock for $1 / 2$-inch and $3 / 4$-inch hose.

Price, each

Per dozen $.05 c$ . $.40 c$

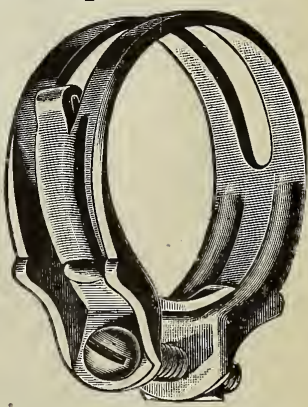

Hose Connection

To conect $1 / 2$ inch hose to spray rod. Price, each (Drift)

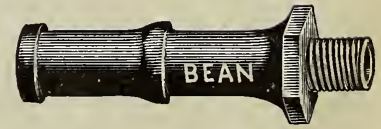




\section{Spraying Extras-Continued}

\section{Hose Reducers}

These are for connecting a male hose coupling on end of spray hose to the spray rod. The two piece connection has a swivel joint and is easy to attach. When the one piece connection is used the entire rod must be turned in screwing on. Price, one piece reducer................. .20

\section{1/4 Nozzle Ell}

It is very important to spray down into the blossom. This piece has just the right angle anl screws onto the end of any spray ror. Then attach the nozzle.

Price each (Jar)
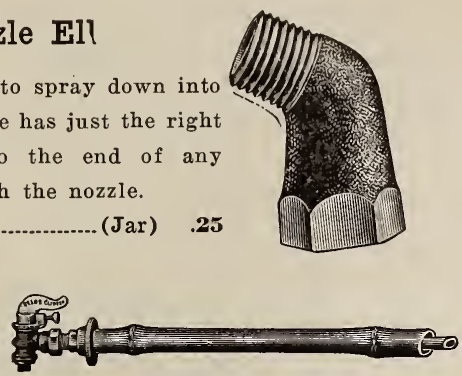

*Extension complete includes Bean Cut-off and any Bean Nozzle.

\section{$1 / 4$ Nozzle $Y$}

The Brass $Y$ shown here will screw on to any spray rod, and all kinds of spray nozzles serew onto the other two ends. nozzles serew onto the other two ends.
This is intended for use when two nozzles on one rod are desired.

Price, each

(Delf) .60

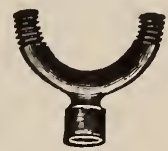

\section{Bamboo Extensions}

The bamboo used in making our extensions is a nice size to hold in the hands and is smooth and little affected by either heat or cold. We regularly fit them with $1 / 8$-inch iron pipe, but can furnish $1 / 4$-inch iron pipe without extra charge. $1 / 8$-inch pipe is perfectly smooth, does not rust or charge. $1 / 8$-inch pipe is perfectly smooth, does corrode, and weighs only one pound to ten feet.

With iron pipe. With alum. pipe

8-foot bamboo extension complete*....\$2.75

$\$ 4.30$

10-foot bamboo extension complete*.. $\mathbf{3 . 0 0}$

$\mathbf{5 . 2 0}$

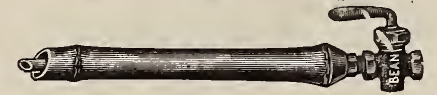

If rod only is wanted deduct $\$ 1.35$

$1 / 4$-inch iron Extension Pipe rod only: $5 \mathrm{ft}, 60 \mathrm{6} ; 8 \mathrm{ft}$. 75c; 10 ft., $90 \mathrm{c}$.

\section{Dust Sprayers}

The principle of spraying to control insects and diseases on plant life is right. In practice the principle advocated and taught by our Theorists is unsatisfactory, unpleasant, laborious and expensive. Principles and practice go to gether. The results from practice determines the cor rectness of the principle. A theory of orchard protection against insects and fungi is of no value until the practical grower has put his O. K. on it. The Dust Spray is championed by the successful practical growers, because it is satisfactory, rapid and easy of application, with a minimum amount of labor, and saves $\mathbf{7 5}$ per cent in spraying expenses. It shows results on the codling moth injuries of less than $1-10$ of 1 per cent in 7,000 boxes export apples, and absolutely controls scab fungus. The system is the result of practical experimentation by the practical growers who have succeeded in its use, the methods so simple that the ordinary man can apply them without error or mistake.

\section{Cyclone}

This is our hand power machine. The bor holds 1 peck of dust, the machine uses $21 / 2$-inch air tube and 8 feet of $2 \frac{1}{2}$-inch spouting, our flexible joint, stand and fixtures, and our book of formulas are furnished free with each machine.

Mode of operation-The machine is carried on a light one-horse wagon, stone boat or sled, or on hilly ground it may be carried by the operators from tree to tree. It has ample power to spray any ordinary sized tree from the ground.

Capacity-One horse and light wagon, and two men can spray from 25 to 40 acres per day, according to the size of the trees.

Weight-Machine proper weighs 65 pounds. Machine and all extras securely packed and crated ready for ship

ment, 100 pounds.

Price-Machine 8 feet of $2 \frac{1}{2}$-inch spouting, 1 flexible joint, stand and fixtures complete, crated, $\$ 29.00$.

\section{EIMPIRE DUST SPRAY For Codling Moth NET PRICE}

$100 \mathrm{lbs}$. and less than $200 \mathrm{lbs}$., per ewt.

$200 \mathrm{lbs}$. and less than $500 \mathrm{lbs}$, per cwt.

$50 \mathrm{lbs}$. and less than $100 \mathrm{lbs}$., per ewt. $\$ 7.00$

$25 \mathrm{lb}$. Buckets, per $\mathrm{lb}$
Good fruit can only be produced by the proper spraying of trees at the right times of the year. 


\section{Dust Sprayers--Continued}

\section{Portable Machine 1902}

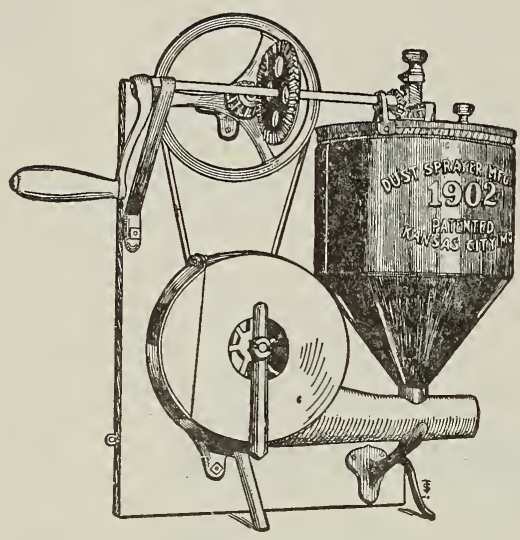

This machine is carried by the operator. The machine and its entire mechanism is securely fastened to a single back piece that is supported close to the body of the operator in front. It is held in position by combined shoulder braces and waist band, adjusted in such a manshoulder braces and waist band, adjusted in such a man-
ner as to throw the weight of the machine on the haunches of the operator. It is easily operated because the body and arms of the operator are in a natural position.

The dust box holds 1 gallon. It has the same feed attachment as the Cyclone, and guaranteed not to choke. The dust box, air tube, and fan shell are made from galvanized iron on exactly the same design as the "Cy-

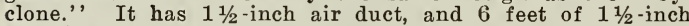
spouting, one flexible joint and one pair of combined shoulder braces with our book of formulas are furnished free with each machine.

Price, Machine, 6 feet of $1^{1 / 2}$-inch spouting, one flexible joint, and one pair combined shoulder braces, all complete and boxed, \$13.00.

\section{“Lightning” Dry Powder Duster}

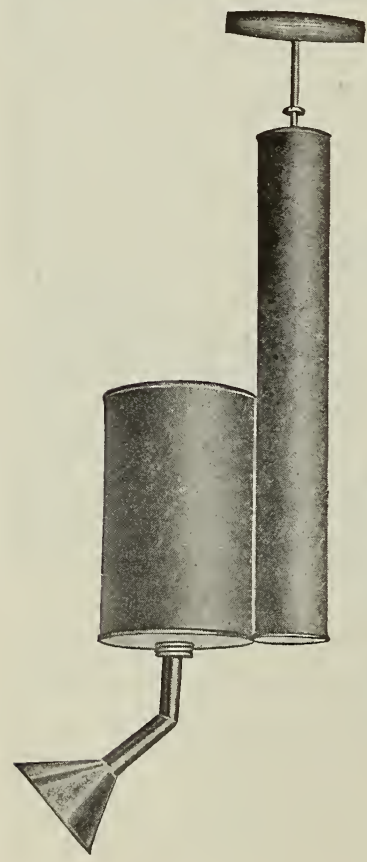

will produce a large or small blast. Useful for exterminating potato bugs, currant worms and all sucking insects. Price, $\$ 1.00$ each.

\section{Spray Material and Washes}

\author{
For Destroying Insects, Scale, Etc.
}

\section{The Two Greatest Fruit Tree Sprays \\ Rex Lime and Sulphur \\ Grasselli's Arsenate of Lead}

The. secret of successful spraying lies in knowing and judging the correct time based on climatic conditions. Certain locations are much warmer and earlier than others; more advanced. Owing to this fact orchardists must watch

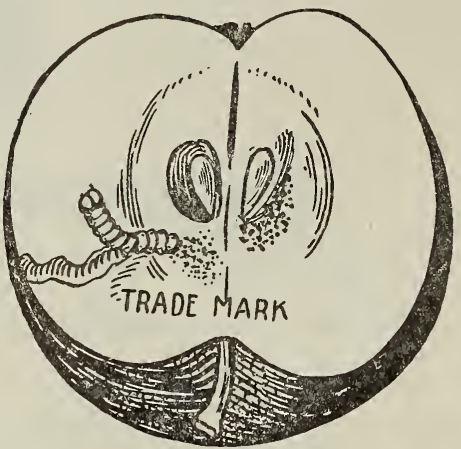

these conditions and use their judgment as to when to spray for the different diseases.

Kindly bear in mind this very important fact that thoroughness in spraying is one of the main points. Many failures can be traced to the lack of thoroughness.

It is also important that the orchardist should become familiar with the name and character of the disease he is to spray for. If the disease is not known apply to your inspector for information. Specimens of diseased fruits or leaves, or other portions of trees or plants, may be or leaves, or other portions of trees or plants, may be forwarded to your state experiment station at no cost, and the disease identified.

\section{Rex, the World's Greatest Fruit Spray}

REX IIME AND SULPHUR SOLUTION makes for better fruit. It means a big earning power. Rex Solution is a true calcium sulphide-a true calcium sulphide means a perfect chemical combination of Lime and Sulphur, absolutely free from all sediment, absolute uniformity which guarantees the same identical treatment as to strength and effect tree for tree and which allows the wash to be applied to delicate bud life, blossom condition wash to be applied to delicate bud life, blossom condition and foliage as well as the dormant tree without injury as well as San Jose Scale, Oyster Shell Bark Louse, Moss, Apple and Pear Scab, Slug Worms, etc. The wide range of disease that fruit trees are subject to that $R e x$ will control prove it to be the best general fruit wash the world has any record of.

\section{For Dipping Sheep and Cattle}

When used according to directions as given on containers, meets all United States government requirements. It is used by the largest owners of sheep and cattle It is used by the largest
throughout the United States.

\section{To All Poultry Raisers}

Of Great Importance-Rex Lime and Sulphur Solution diluted 1 to 5 , one gallon to five gallons of water for spraving. your Poultry House for destroying Lice, Mites spraying your Poultry House for destroying Lice, Mites purpose on the market, and is sprayed for One Tenth the Cost.

\section{Important}

- In order to have your wants supplied with Rex Lime and Sulphur for Early Spring Spraying, Garden and Field use we advise growers to book their orders in person or by mail, this will insure delivery. Price, gallon, 75c; 5 gallon, \$2.50; barrels, \$12.50. 
Spray Materials, efc.-Continued

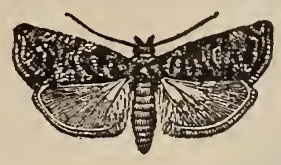

\section{GRASSELLI'S ARSENATE OF LEAD- PASTE}

For the Destruction of the Codling Moth and

\section{Leaf-Eating Insects}

Every farmer and orchardist who is anxious to increase the value of his product should get ready to fight the "Codling of his,

It is possible for apple growers in badly infested regions to save more than 85 per cent of the fruit which, without treatment, would become wormy.

The authorities tell us that the "Codling Moth" is twobrooded. The number of worms of the second generation is larger than the first and naturally more destructive.

To avoid damage by the second generation, reduce the number of the first. In order to accomplish this, it is absolutely necessary to spray thoroughly with a reliable insecticide just as the blossoms are falling. The object is to poison the young larvae before they enter the fruit. The larvae get the poison while feeding on the leaves, or in the calyx or on the sides of the fruit and are killed. Do not let the orchard get overrun with worms by inattention to one year's spraying. We refer more particularly to the "Codling Moth" because it is, of all insects, the to the "Codling Moth because it is, of all insects, the in the orchard. Grasselli's Arsenate of Lead-Paste can be in the orchard. Grasselli's Arsenate of Lead-Paste can be the Gypsy Moth, Brown-tail Moth, Potato Bug, Elm Leaf Beetle, Canker Worm, Etc. Spray with Grasselli's Arsenate of Lead-Paste for the destruction of the Codling Moth.

Directions for Use.-Dissalve 1 to 2 lbs. in 50 gallons of water. When using a hand pump with 40 to $60 \mathrm{lbs}$. pressure, more should be used than with a pump working at 120 to $160 \mathrm{lbs}$. pressure.

The first spraying should take place immediately after the blossoms fall and the best results are obtained by forcibly throwing plenty of coarse spray from a height down into the Calyx cups. The nozzle about two feet above the blossoms.

About five sprays during the season is sufficient at intervals of about one month apart.

Coat all sides on every fruit. Don't expect the spray

to go around the corners. lb. keg, \$2.25; 25-lb. keg, \$4.25; 50-lb. keg, \$S.00; 100 lb. keg, \$15.00.

The Grasselli Chemical Co.

Pullman, Wash., Sept. 28, 1907. St. Paul, Minn.

Gentlemen: We have recently made an analysis of the sample of Arsenate of Lead which you submitted to us several weeks ago. We find that it contains 17.09 per cent Arsenic Pentoxide and 41.62 per cent Lead Oxide. These Arsenic Pentoxide and 41.62 per cent Lead Oxide. These sample which we have ever analyzed of any brand of Arsenate of Lead now being sold in this state. Your preparation is therefore of very high strength, and we find it to be also in excellent physical form, and would have no hesitancy in recommending it as a very high grade product. You are at liberty to use this statement in any product. You are at liberty to use this state

(Signed) R. W. THATCHER, Director of Experiment Station.

\section{Paris Green}

Poor Paris Green is dear at any price. The brand we handle is warranted strictly pure and will comply with state laws. Effective against all chewing insects. 1-lb. pkg., 45c; 2-lb. pkg., 85c; 5-lb. pkg., \$2.00.

\section{Whale Oil Soap}

Used as a summer spray for hop louse and green aphis. 1-lb., 10c; 100 lbs., market price.

\section{Quassia Chips}

Used with Whale Oil Soap for lice on cabbage, cauliflower, etc., and on fruit trees. Lb., $\mathbf{1 0 c}$.

\section{Hellebore}

Especially used for destroying turnip, currant, and gooseberry worms, larvae of sawfiies, etc. 1 lb., $40 \mathrm{c}$.

\section{Kerosene Emulsion}

Will kill suctorial insects. 1 qt., in tin cans, $60 \mathrm{c} ; 1$ gallon, in tin cans, $\$ 1.50$.

\section{Hammond's Grape Dust}

A preparation to kill mildew on grape vines, rose bushes, and other vines, also kills mold, rust, etc. Price, $\mathbf{1 5 c} \mathrm{lb}$; 50c for 5 lbs.

\section{Tobacco Dust}

One of the best remedies for green and black aphis, fleas, beetles. Price, $1 \mathrm{lb} ., 10 \mathrm{c} ; 10 \mathrm{lbs} ., 75 \mathrm{c}$.

\section{Sulphur}

Powdered, lb., 5c; 100 lbs., market price.

\section{Bluestone}

Used successfully in the winter sprays. Per Ib., 15c. If wanted in 100-1b. or barrel lots, market price.

Buhach, per oz., 10c; 1/4 lb., 30c; 1 lb., \$1.00.

\section{Sulpho Tobacco Soap}

A sure, immediate and convenient exterminator of al insect life and vermin on plants, shrubbery, vines, smal fruits and trees. Non-poisonous and absolutely safe to handle. It will not injure the tenderest growth. A powerful fertilizer, reviving plants wilted from the ravages of insects. Pkg., 10c and 20c.

\section{"Planet Jr." Farm and Garden Tools}

No. 1, Combined Drill Seeder, Wheel Hoe, Cultivator and Plow. Price, complete, $\$ 10.50$. Seeder only, $\$ 8.50$.

This tool is known and used the world over, and except ing our hill and drill seeders, is the most perfect drill known. The hopper holds three pints, and sows in an even, regular stream, whether there is much or little seed in it. The machine is extremely simple has no aitators belts or gearing, and will not injure any seed. From a drill it is changed to its other uses by removing two bolts, when hoes, cultivator teeth or plows can be quickly attached. It is a practical everyday time and labor saver a grand remedy for the backache, and the best low priced combined machine on the market.

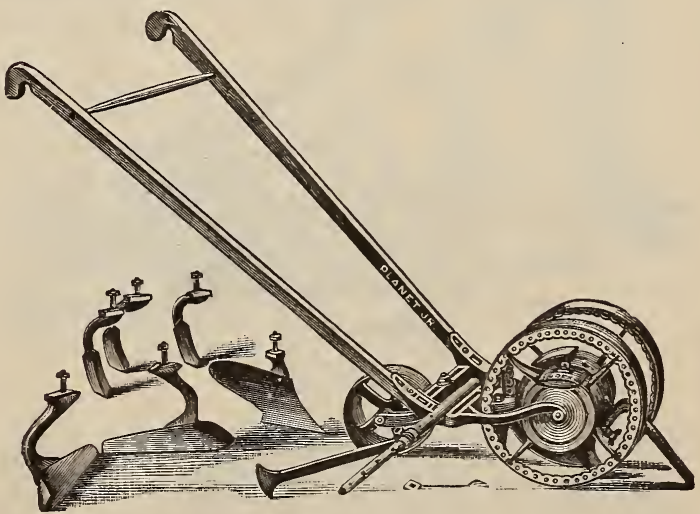

Space will not permit our showing and describing all of the "Planet Jr." Tools, but we will send a full illustrated catalog free for the asking to any one desiring it, and we can supply promptly anything ordered. "Planet Jr." goods are standard machines, the best on the market. In sending your orders to us you can rely on getting bottom prices. 


\section{"Planet Jr." Farm and Garden Tools-Continued}

No. 6, Planet Jr. Combined Hill and Drill Seeder, Wheel Hoe, Cultivator and Plow. Price, $\$ 14.50$.

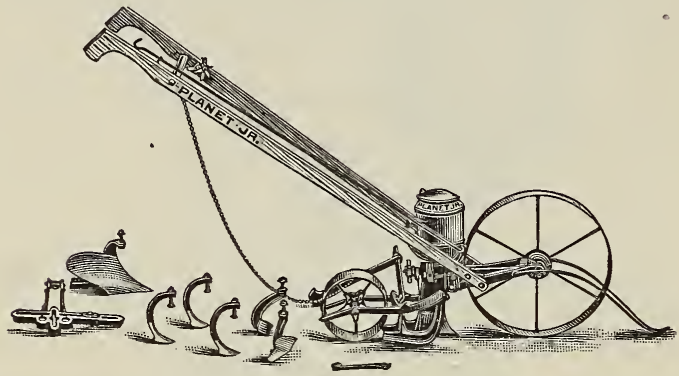

This, our latest Planet Jr. Seeder has been under construction for two years, past, and has been held back until every detail has been made as nearly perfect as possible. The steel carrying wheel is $16 \frac{1}{2}$ inches high, with forged steel spokes, making an easy running tool. With forged steel spokes, making an easy running tool. Handles adjustable. The feed and cut-off are the most is of a new shape, leaving the seed in a narrower row than any plow we have heretofore made. The roller is large and wide, leaving the seed in excellent condition for germination. This drill sows in drills, drops in hills, $4,6,8,12$, or 24 inches apart, covers, rolls down and marks the next row, all in one passage. As a wheel hoe the frame is similar to our No. 17, Single Wheel Hoe and equipped with the same tools. The combination is the best and most useful we have ever offered.

Planet Jr. No. 25, Combined Hill and Drill

Seeder, Double Wheel Hoe, Cultivator and

Plow. Price, $\$ 14.50$.

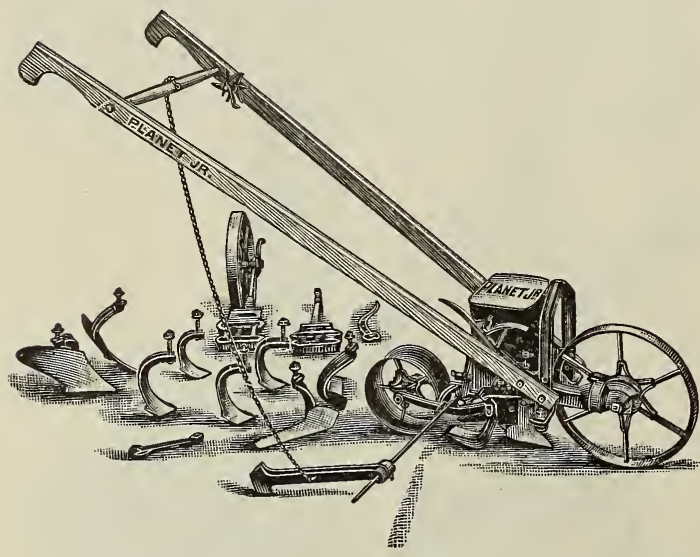

This new combined machine is intended for gardners who have a large enough acreage in crops for a Double Wheel Hoe to be used to good advantage, and prefer not to buy separate machines.

As a drill it is almost identical with the Planet Jr. No. 4 drill, and is thoroughly substantial and accurate in sowing all kinds of garden seeds in hills or drills.

As a Wheel Hoe it is identical with the Planet Jr. No 12 Double Wheel Hoe, the very best machine on the market. The change from Drill to Wheel Hoe takes but a moment and the whole combination is one we can heartily 'recommend and guarantee satisfactory.
Planet Jr. No. 17, Single Wheel Hoe, Cultivator and Plow. Price, $\$ 6.00$.

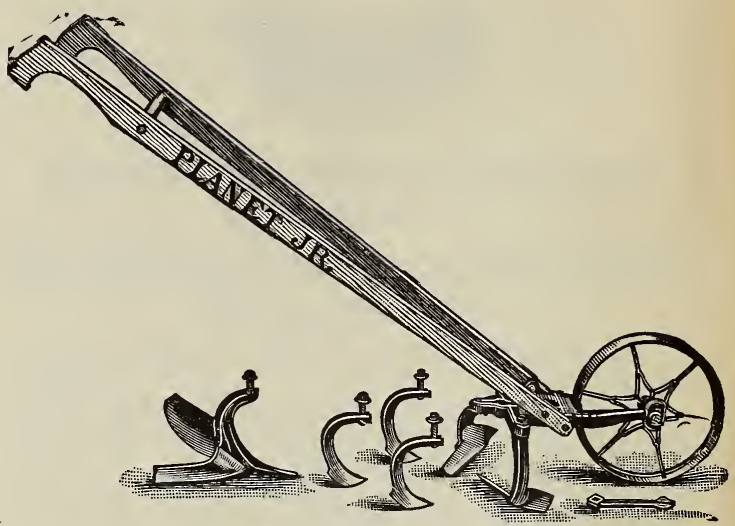

For easy gardening and at the same time clean and perfect gardening, the kind that will make your garden the talk of the neighborhood, and cause your face to glow with honest pride, nothing is quite the equal of this No. 17 Wheel Hoe. It is suited to all kinds of garden cultivation and all garden crops. You can do more and better hoeing with it in one day than you can do in three days with a hand hoe. The No. 17 has a pair of 6-inch hoes, a plow and a set of cultivator teeth, an outfit sufficient for most garden work.

Other attachments can be aided at any time.

Planet Jr. No. 4, Combined Seed Drill, Single

Wheel Hoe, Cultivator and Plow. Price, complete, $\$ 12.00$. Seeder only, $\$ 10.00$.

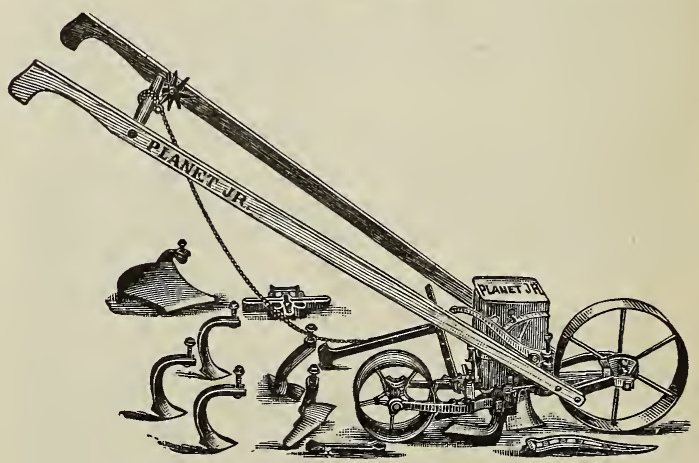

This is the most popular combined tool made. It combines in seeder, a Single Wheel Hoe or weeder, a cultivator and a plow. The hopper holds two quarts of seed, which can be sown in continuous rows, or dropped in hills at 4 , $6,8,12$ or 24 inches apart.

The drill is detached and the tool frame substituted by removing but one bolt. It then becomes a single wheel hoe. It is useful almost every day of the season, at every stage of the garden work. With this one implement the small farmer can do practically all the work in his small crops.

"Planet Jr." Garden Tools are always reliable. There are none better for general garden work. 


\section{"Planet Jr." Farm and Garden \\ Tools--Continued}

Planet Jr. No. 12, Double Wheel Hoe, Cultivator and Plow. Price, $\$ 8.00$.

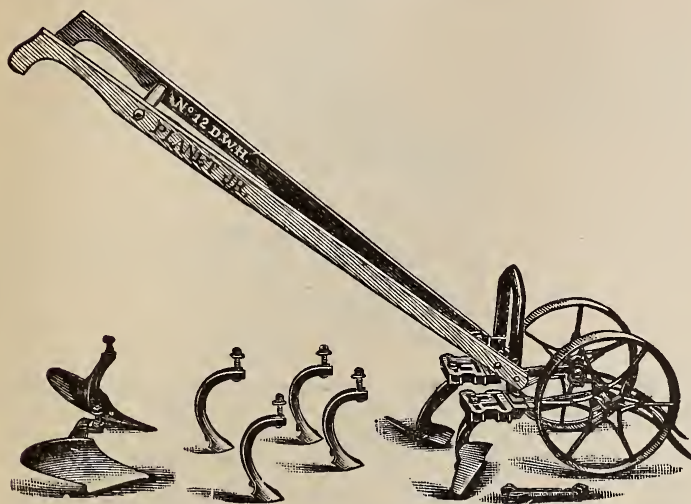

Two acres a day can be easily worked with this implement, and when it is done it will be a better job than ment, and when it is done it will be a better job than three men could have done with hand hoes. The No. 12 runs either astride or between the rows; kills all the
weeds and leaves the earth in fine shape. Then, too, it's so easy to work. Twelve-year-old girls work gardens with them with ease and success.

The No. 12 has a pair of 6-inch hoes, a pair of plows for opening or covering, and a set of 4 all-steel cultivator teeth. The tools shown are what gardners use most and others can be added as wanted.

Planet Jr. No. 8, Horse Hoe and Cultivator. Price, $\$ 11.00$.

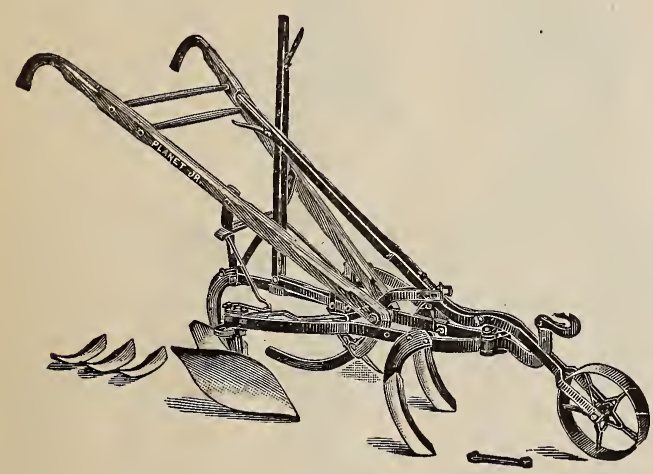
Probably no other cultivating machine is so widely
known as the Planet Jr. Combined Horse Hoe and Cultiknown as the Planet Jr. Combined Horse Hoe and Culti-
vator, for it is in use throughout the civilized world. It is so strongly built as to withstand incredible strain, yet it is light and easy to handls. You can do almost anything you want with it in the garden or field. It opens and closes furrows, hoes right up to the plants without danger of injuring, throws dirt to or from the row and throws back from center again. You can set the hoes at any angles or reverse altogether cultivate to the hoes at any and adjust for any width. Every part is perfected to make the tool acceptable to the intelligent farmer who knows the best is always the cheapest.

For Arsenate of Lead and prices for same, see page $4 \mathrm{I}$
Planet Jr. Twelve-Tooth Harrow, Cultivator and Pulverizer. Price, plain, $\$ 7.80$; with wheel, $\$ 8.35$; complete, $\$ 11.00$.

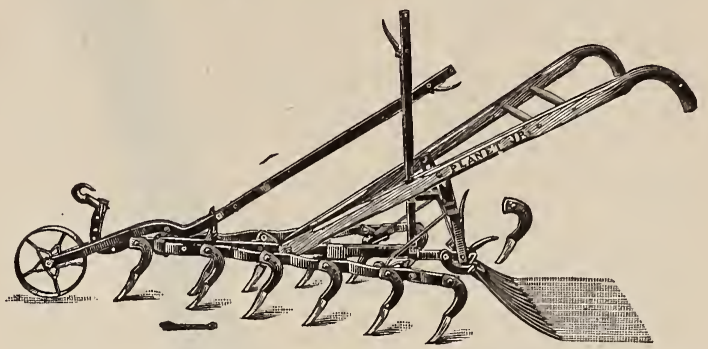

Gardeners cultivate better than formerly. It has been found to pay best. The farmer or gardener is most likely to cultivate best who has the tool best adapted to his purposes. With the Twelve-Tooth Harrow here shown, you go as deep or shallow as you like, come up close to row without injuring plants, cut out all the weeds, stir the wil and mellow and fine it as with a garden rake. the soil and mellow and fine it as with a garden rake. inches. It's a special favorite with strawberry growers, market gardeners and truckers.

\section{The "Segment" One-Hand Corn and Bean Planter}

The seed pocket can be sufficiently enlarged to perfectly adapt it for planting the largest field beans as well as corn. The field beans as well as corn. The slide is an arc of a circle hav-
ing its center where the jaws are pivoted together. In other words, the pivots on which the jaws open and shut are the hub of a wheel of which the slide is a part of the rim. There is consequently no friction nor lost motion. Price, $\$ \mathbf{1 . 7 5}$.

THE ECLIPSE ROTARY CORN PLANTER-Decidedly the best hand corn planter made and a very desirable implement for those who have a quantity of corn to plant. It puts the corn exactly where you want it, and at a proper depth. It is easily worked and a most satisfactory tool in every way. Price, \$1.50.

TRIUMPH CORN PLANTER-Has no objectionable features; is made of good material. Has Iron Seed Box and Iron Channel; foot of polished steel. strong, durable, and gives universal' satisfaction. Price, $\$ \mathbf{1 . 2 5}$.

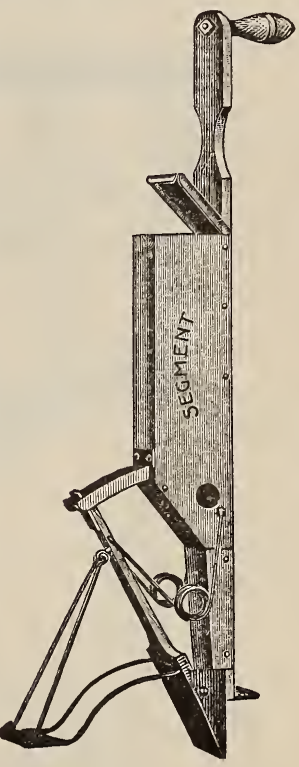

Lang's Weeder

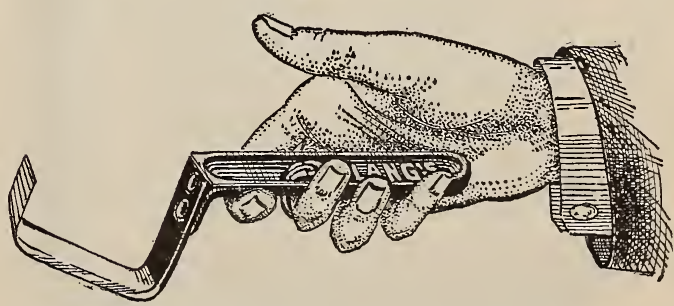

It is very conveniently used, and fits the hand so com. fortably that the fingers are entirely free for use wherever necessary. Net price, 25c; postpaid, 30c. 

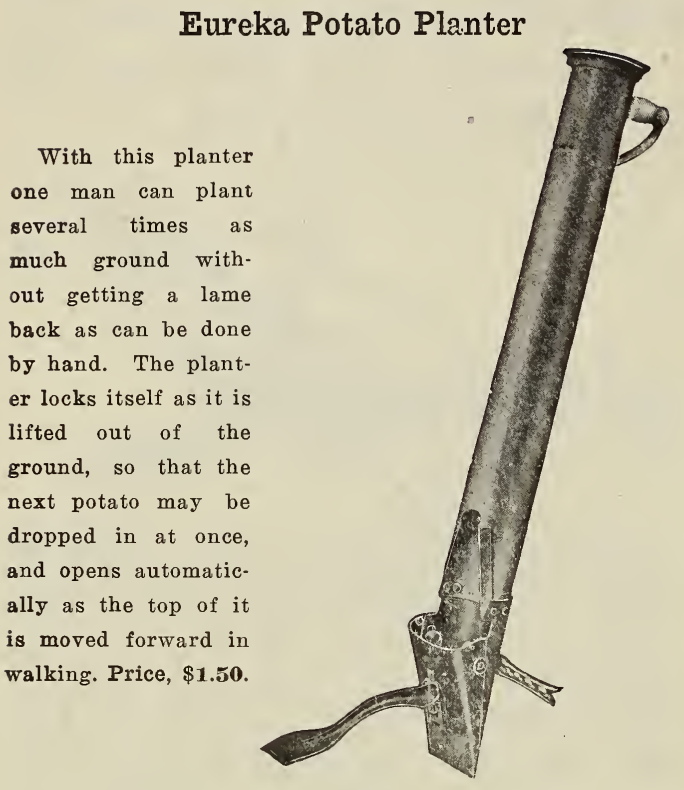

The New Cyclone Seeder

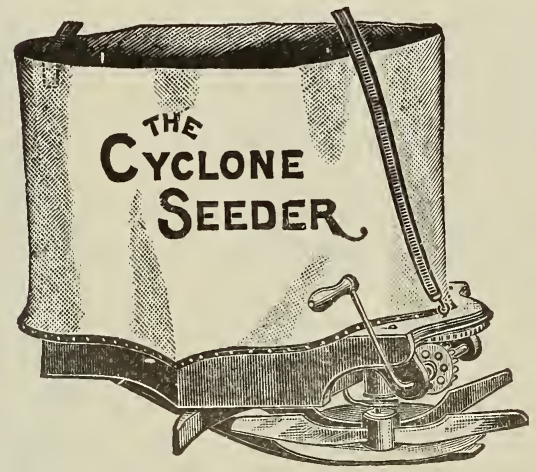

Will sow timothy, clover, oats, red top, turnip, millet, corn, cotton, and all other grains and seeds perfectly even and any desired amount to the acre, and from 40 to 60 acres a day. Price, \$2.25.

National Broadcast Seeder

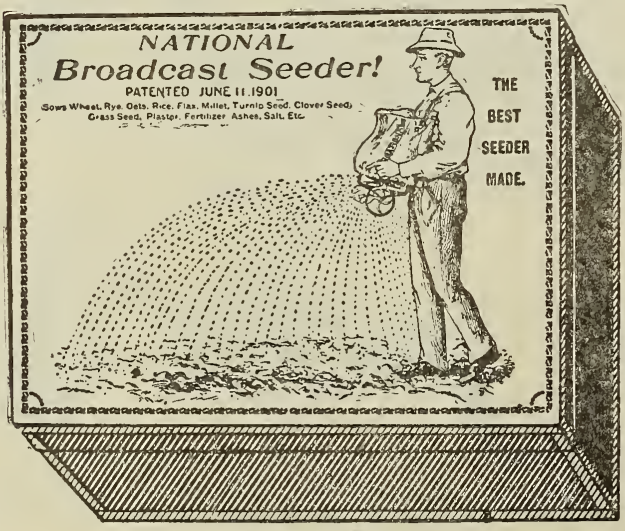

Price, each, \$2.00.
BLACK HAWK CORN SHELLER

A Sheller That Shells

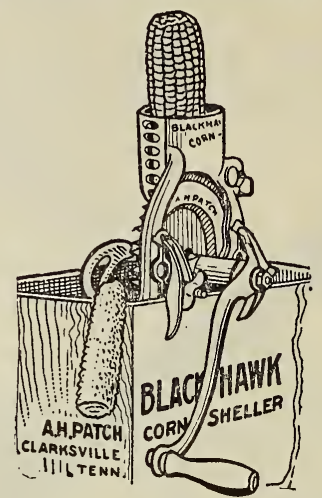

It can be set to shell any corn that grows. Set it for popcorn and it will shell pop corn; set it for field corn and it will shell field corn; set it for the largest corn that grows and it will shell the largest corn that grows. That is why it is so much better than other grows. Made with ball-bearings, obviating the expense types. Made with ball-bearings, obviating the expense
of a heary balance wheel. Easily fastened to box by thumb-screw-no bolts nor screws required-no holes to be bored. Price, \$2.50.

\section{PRUNING TOOLS, KNIVES, WEEDERS,} ETC.

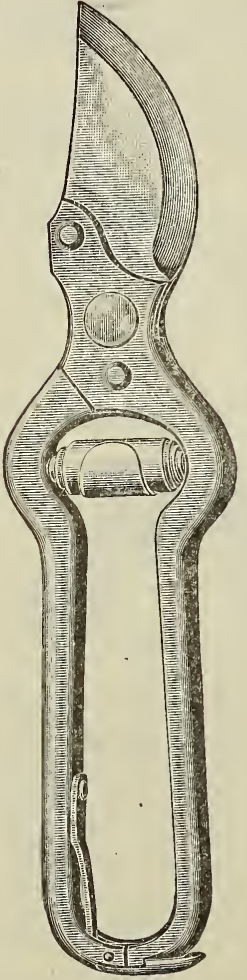

No. 40 .

\section{Pruning Shears}

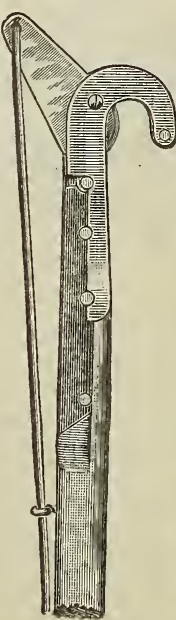

No. 20.

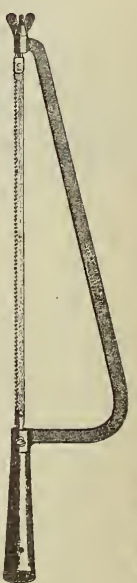

No. 15.

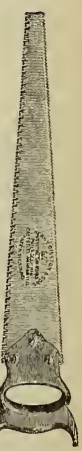

No. 10.
No, 40. Nine inch; bright finish, polished blade, spiral steel spring; made for hard service. Price, \$1.25; postpaid, $\$ 1.40$.

No. 30. Similar to No. 40. A good low priced tool. Price, 60c; postpaid, $75 c$. 


\section{Pruning Tools}

\section{Long Handle Tree Pruners}

No. 20. Indispensable in pruning tall trees. (See cut No. 20.) Cannot go by mail. Purchaser will have to pay freight or express charges. Price, $\mathbf{S}$ feet, \$1.00; 10 feet, \$1.10.

\section{"Perfection" Pruning Saw \\ See Cut No. 15.}

Made of best steel with adjustable blade, so any branch can be easily removed and close to trunk of tree. Can be used as a hand saw or fastened to any sized pole. The best saw on the market. Each, \$1.75; extra blade, 25c.

\section{Duplex}

See Cut. No. 10.

A double-edged saw, with fine teeth on one side and coarse teeth on the other. Price, 75c.

\section{Califormia Crescent}

A curred saw with teeth on the concave side; best quality steel. Price, $75 \mathrm{c}$.

\section{Cream Separators}

The Empire Easy Running Cream Separator

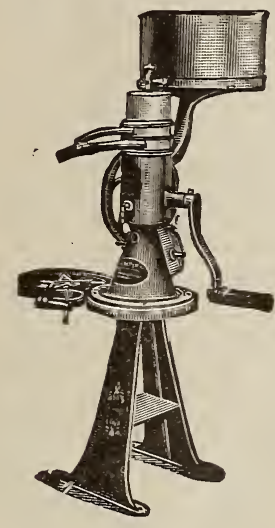

The Improved Frictionless Empire is the product of long years of development. It represents the highest, the very top notch of separator construction.

It meets every requirement when judged by the severest standards of experienced mechanics. That, in a senes, is the theoretical side. The practical every-day-work's side is proven by thousands and thousands of cow-owners in all parts of the country who have adopted and are using the Improved Frictionless Empire with perfect satisfaction after having tried and tested many other types of tion after

The Frictionless Empire is built for people who want the best. For people who are not satisfied with things that "will do." For people who want not only more money, but the most money possible from their dairies. If you are that kind of a farmer you will understand that the best is the cheapest in the end. You will realize that the buring of a separator should be looked upon as an investment. You will consider the future returns, the future profits, instead of the first cost.

profits, instead of the first cost.
And you will select the Frictionless Empire, because it is the separator that will make the most dollars for you. The Empire has found its way not only into the homes, but into the hearts of hundreds of thousands of users. Why? Because it has proven in the language of many, "better than you said it was.", Because it is relieving the drudgery of dairying even such drudgery as is connected with the operation of an ordinary cream separator nected with the operation of an ordinary cream separator.
Its frictionless ball bearings make the turning of it a pleasure rather than a task. Its patent protected skimming device, its patent protected ball bearings have made it the model of cream separator construction. But it's a model that other manufacturers cannot approach for vears to come, not until our paterits run out. So if you want the

\section{Branch Shears}

With handles 26 inches long; will cut stick $11 / 4$ inches in diameter. Price, $\$ \mathbf{1 . 2 5}$.

\section{"Lightning" Grass Trimming Shears}

For trimming ground flower beds, etc. Each, 50c; by mail, 65c.

\section{Garden Trowels}

A good steel trowel. Price, 35c; postpaid, 50c.

\section{Grafting Wax}

$1 / 2$ lb., 20c; 1b., 35c; postage, 18c per lb.

\section{Separator Oil}

White Rose. Price, qt., 35c; gal., 85c.

\section{Dairy Thermometers}

rrice, 35c; postpaid, $45 \mathrm{c}$

best, all 'round everyday, easy cream separator, we still say to you as we have said in the past, get the Improved Frictionless Empire.

When you want anything you want the best of its kind. That's business. Here are some things you must have in a separator if you want to get one that is worth your while buying.

The best separator must skim clean; it must get all the butter fat from the milk. We guarantee that no separator in the world has a better skimming record than the EMPIRE.

The best separator turns easily. The easy running EMPIRE turns more easily than any other separator of equal capacity.

The best separator is simple in construction. Its light bowl and few parts make the EMPIRE the simplest separator made.

The best separator is easily cleaned. This is one of the most important requirements. A seperator must be washed thoroughly after every skimming. If it is not, the grade of the cream becomes poor and of less value A complicated machine means a lot of trouble keeping it clean, and in some cases it is impossible to do.

The Empire Eeasy-Running Cream Separators are built

in sizes and capacities to meet all needs.

Our Illustrated Catalog describes it in detail.

If you haven't one, let us send it.

Write for catalog and prices.

This Is the Empire Gasoline or Gas Engine

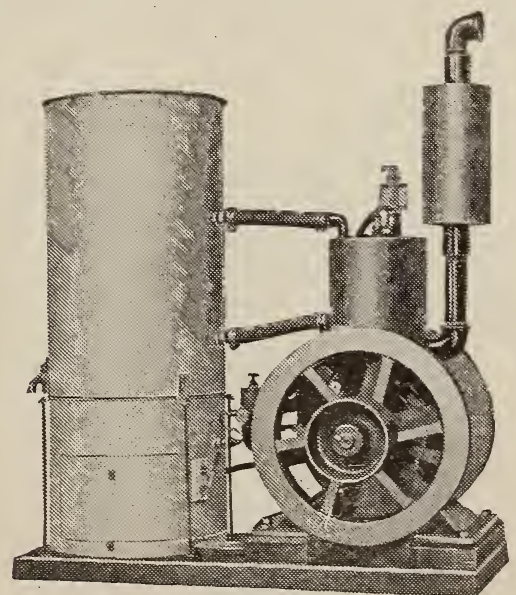

Fully Equipped. Ready for Use. It is made in two sizes, $\mathbf{1} 1 / 2$ horsepower and $\mathbf{3}$ horsepower. Choose the one that fits your needs.

Being the first perfected type of the 2-cycle gasoline engine, being the lightest and the simplest built, and con- 


\section{EMPIRE GASOLINE ENGINE}

sequently having fewest parts to wear and fewest points of friction. It will give you more power and steadier power, with less trouble and at less expense than any other engine of its rated capacity.

There are scores of gasoline engines on the market, of course and there have been for years past. But they don't course, and there have been for years past. Butse or else fit. They are either too heavy and cumbersome, or else nary use-they waste too much power.

And that isn't all. The main trouble with most gasoline engines is, and has been, they are too jerky, too uneven in their work. They are of heavy, horizontal, foureycle type, and if connected to a cream separator or other machine on the farm, rack and tear it to pieces.

The Empire Cream Separator Company, being authority on cream separators, has studied and found just the power needed to run the average separator, and in doing so we have found as well the best power, the best engine to do the hundred and one other little jobs about the farm.

EMPIRE ENGINE NO. 1, 1 $1 \frac{1}{2}$ horsepower. $\$ 75.00$ EMPIRE ENGINE NO. 2, 3 horsepower 125.00

\section{BEE HIVES AND MATERIALS} Hives

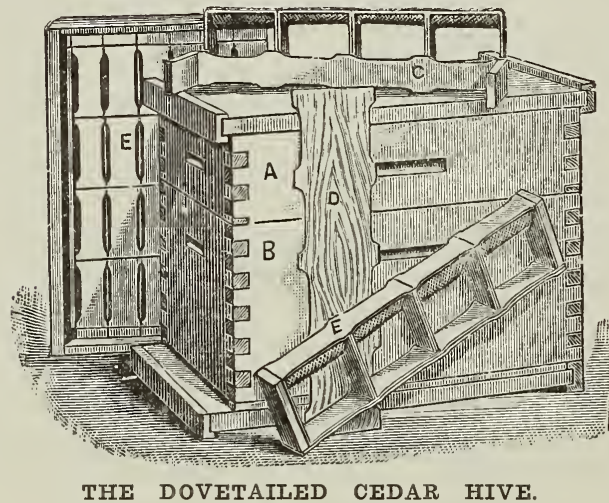

Our hives and inside fixtures are made of thoroughly kiln-dried cedar, selected expressly for the manufacture of beehives and show superior workmanship by thoroughly competent men, who have had years of experience in the manufacturing business. They are the most durable hive that is made and will stand any climate.

All of our hives are eight frames as these have become the most generally used, as it has been found that in the production of comb honey, eight frames are about all that an average queen will cover with brood and it is desirable to have all the surplus put in the supers.

Our hives combine all of the improved features that are practical, and we have taken great pains to produce the most perfect hive for the money, and we believe that an examination of our hives will convince you that we have succeeded.

The dovetailed hive is now generally used and we believe that it is a much superior make to the old rabbeted hive. It is much stronger in construction; it goes together easily, It is much stronger in construction; it goes together easily, and when properly naled is very durable; it does not check or warp, shrink and swell like a pine hive, when
exposed to the weather. Every hive is furnished either with a flat cover or the improved Higginsville cover which is a combination of the flat and gable covers. We put up this hive for shipment in lots of five by simply crating the pieces together, or packing them in solid crates. No. 1 Dovetailed Hive (complete with one super), consists of 1 ovetalle brood frames, 1 division board, 6 section holders, 6 slotted brood frames, 1 division board, 6 section holders, 6 s
separators. Price, 5 K. D., $\$ 10.00 ; 1$ nailed, $\$ \mathbf{2 . 2 5}$.

SUPERS-Same as for above hive. Each, 75c; 5 in flat, $\$ 3.25$.

HOFFMAN FRAMES-10 for 35c; 100, \$3.00. SECTION HOLDERS-10 for 30c; 100, \$2.50. SLOTTED SEPARATORS-10 for 10c; 100, 85c.

\section{Eastern Pine Hives}

We also have a 10-frame Eastern pine hive. Price, 1 1/2 story, complete Price, 5 K. D.

\section{Bee-Smokers-Corneil}

We recommend this smoker as the most useful for an apiary. It holds the fire well, and after standing for some time will throw out a large volume of smoke at almost the first blast of the bellows. It will also outlast the Clark, two to one, making it cheaper in the long run. Each, \$1.00; postpaid, \$1.25.

\section{Clark's Cold Blast Smoker}

It does the work very nicely where only a few hives are kept, but is a little troublesome when fire is kept too long. Price, 75c; postage, 20c.

\section{Section Honey Boxes}

These are made of the very whitest basswood, smooth on both sides, and are the best quality in every respect. Per 100, 70c; 500, \$2.75.

\section{Price of Comb Foundation}

Medium Brood, per lb. $60 \mathrm{c}$ Thin Super, per Ib.

\section{Daisy Fountain Fasterer}

This is the best for putting starters into sections. Noth ing could be more simple or easily operated than this machine, and we are sure it will put starters in better and faster than any machine before produced. With this a boy or girl will put starters in about 500 sections per hour, and do it nicer than any of the presser machines we formerly sold. Complete directions accompany each machine. Price, with lamp, $\$ 1.25 ;$ without lamp, $\$ 1.00$ weight, without lamp, 5 lbs.

Bee Veils, Cotton, each $40 \mathrm{c}$

Zinc Honey Boards, each $\mathbf{3 0 c}$

\section{Entrance Guards}

These are made of queen-excluding zinc, and are to be placed at the entrance to prevent swarming temporarily. We place them at the entrance Saturday evening, so no one will have to watch for swarming Sunday; we also use them after hiving a swarm to prevent absconding. Price them after hiving a swa

Alley's Combined Drone and Queen Trap

A perfect non-swarming arrangement. Each, 50c; by mail, $70 c$.

\section{BEE-KEEPERS' SUPPLIES.}

We carry a full line of bee-keepers' supplies. Space is too limited here to describe the numerous articles in this line, but if interested write us for further particulars, and we will be pleased to quote prices on supplies of all kinds, of the latest and most approved makes. 


\section{CORBETT'S Single Comb Buff Leghorns}

Are bred for Fancy and Utility.

Eight years a breeder of the Golden Buffs. My strain consists of the best blood that money could buy.

Eggs from three grand pens. \$I.5O per I 5 ; \$2.50 for 30. WILIARD C. CORBETT, Lock Box 195 .

\section{Guaranteed Fertile Eggs}

From prize winning stock from the following: Single and Rose Comb White Leghorns, Black Leghorns, Black Langshans, Black Orpingtons, Barred Plymouth Rocks, Single and Rose Comb Rhode Island Reds, Golden Laced 2nd Buff Wyandottes, and Houdans. Address

\section{Rusk Bros. Poultri Farm,}

R.F.D. No. I

Coeur d'Alene, Idaho

\section{Additional Spraying Apparatus}

Owing to delay in arrival of illustrations for these pumps in nrder to properly classify them we are compelled to insert them on this page. The general description and prices on spray pumps and materials will be found on page 36 of this catalog.

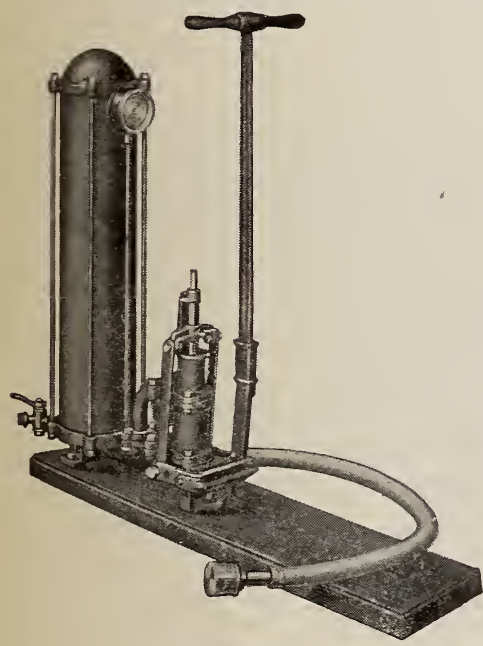

Fig. 633

\section{THE SAIISON DOUBLE-ACTING SPRAYER}

\section{For Barrel or Tank}

The "Samson," Fig. 633, is a powerful pump, having a large number of vantage points not found in other sprayers. We recommend this outfit where a large number of trees are to be sprayed and where a heavy pressure is desired.

The pump has an extrcmely large air chamber (18 gallons capacity), allowing the operator to pump and rest alternately. It has a long, well balanced lever, which is a great aid in pumping. The cylinder is brass-lined and all other working parts, including the ball valves and seats, are brass.

Having a differential plunger, an equal amount of work is done on botb strokes, making it double-acting, which decreases the labor and increases the work done. All parts are easily accessible and the air chamber can bo readily taken apart. There are no stuffing boxes in this pump.

readily taken apart. There are no stuffing boxes in this pump. lined suction hose and strainer and pressure gauge. Shipping weight about 175 pounds.

\section{PRICE LIST}

Fig. 633, as illustrated and described, \$40.00.

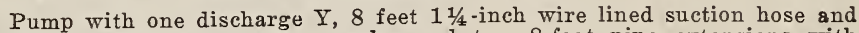
strainer, pressure gauge, two nozzles and two 8-foot pipe extensions with shut-off valves, \$44.00.

\section{THE CAPTAIN BARREL SPRAYER}

The "Captain" is in the front rank of all sprayers of its class. It is a medium price outfit for the every day farmer, fruit grower and gardener.

The pump is made in one size with $1 \frac{3}{8}$-inch brass tube cylinder; has brass ball valves and valve seats, and brass plunger with improved packing. The air chamber is ample in capacity and is made of $2 \frac{1}{4}$-inch boiler tubing. The discharge connection is fitted for $1 / 2$-inch hose.

The "Captain" Sprayer has an improved adjustable clamp for attach. ing rigidly to the inside of barrel. The agitator is simple in construction and very efficient. No pains have been spared to make it the best barrel sprayer for the price.

Shipping weight, pump only, crated, about 40 pounds.

\section{PRICE IIST}

The "Captain" Barrel Sprayer only with male hose connection, fits our $1 / 2$-inch, Fig. 949 , hose coupling, $\$ \$ .00$.

Pump as above with $12 \frac{1 / 2}{2}$ feet $1 / 2$-inch hose, nozzle and connections, $\$ 11.00$.

This does not include barrel.

8-foot iron pipe extension rod, $\mathbf{7 5 c}$.

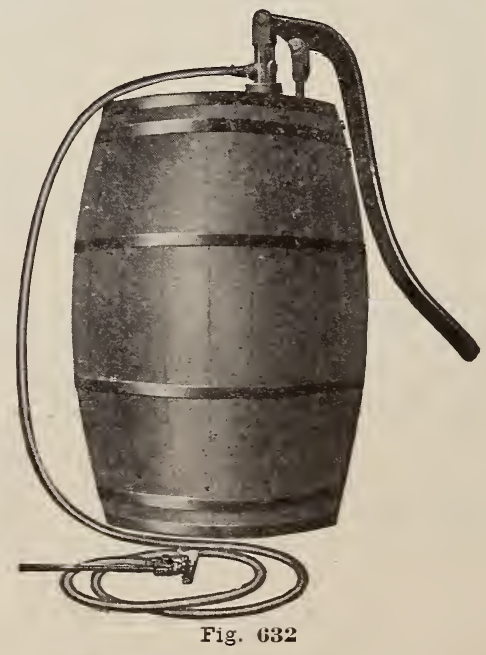

See Page 36 for Other Spray Pumps and IMaterials. 


\section{USEFUL TABLES}

Quantity of Seed Required for a Given Number of Fills.

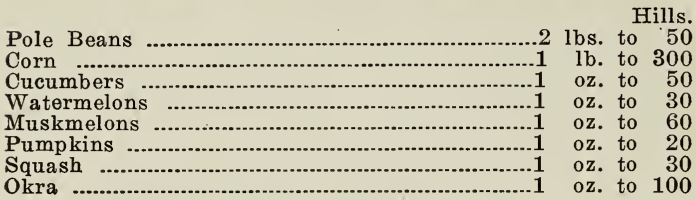

Quantity of Seed Required for a Given Length of 'Drill.

Asparagus
Beet

Table Showing the Number of Plants or Tree to the Acre at Given Distance.

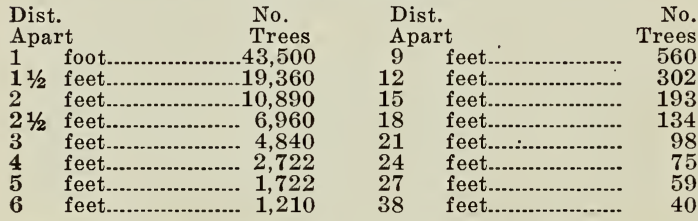

Quantity of Seed Required for a Given Number of Plants.

Asparagus
Cabbage

Weights Per Bushel and Amounts of Seed Sown to the Acre.

\begin{tabular}{lllrr} 
& & Lbs. & \multicolumn{3}{c}{$\begin{array}{c}\text { No. Lbs. } \\
\text { Per Bu. }\end{array}$} \\
to Acre. \\
Alfalfa Clover
\end{tabular}

\begin{tabular}{|c|c|c|}
\hline rley & 60 & \\
\hline & & \\
\hline Orchard Grass & 20 & \\
\hline Hungarian ..... & 25 & \\
\hline Common Millet & 25 & \\
\hline German Millet & 25 & \\
\hline 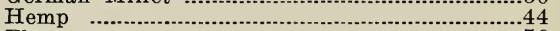 & 35 & \\
\hline & & \\
\hline Buckwheat & & \\
\hline Rye ............ & 60 & \\
\hline .60 & 60 & \\
\hline e for Fodder..........................50 & & \\
\hline - & & \\
\hline 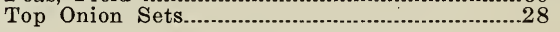 & & \\
\hline
\end{tabular}

In Drills.

No Lbs.

to Acre

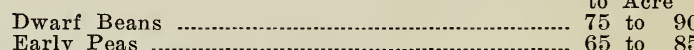

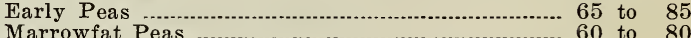

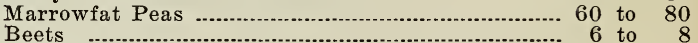

Mangel Wurzel .............................................................. 4 to 6

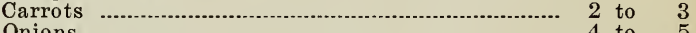

Onions for Sets............................................................................... 20 to 30

Onions Sets

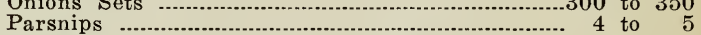
Parsnips

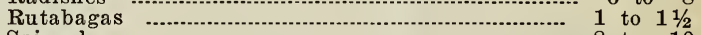

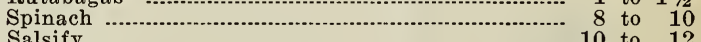

Squash …................... 110 to 12

Table to Assist Farmers and Gardeners in Making an Accurate Estimate of the Amount of Land in Different Fields Under Cultivation.

10 rods $\mathrm{x} 16$ rods equal

8 rods $\times 20$ rods equal.

5 rods $x 32$ rods equal

4 rods $x 40$ rods equal.

5 yards $x 968$ yards equal

10 yards $\times 484$ yards equal

40 yards $\times 121$ yards equal

209 feet $\times 209$ feet equal...

200 feet $\times 108.9$ feet equal

100 feet $x 145.2$ feet equal

100 feet $x 108.9$ feet equal

Weight of Different Manures to Apply to Different Crops Per Acre.

Potatoes (..................................... Stable 15 to 30 tons Mangel Wurzel .................................... Stable 20 to 30 tons Carrots .......................................... Stable 12 to 20 tons Beans .............................................. Stable 12 to 20 tons Nitrate of Soda and Potash Salt

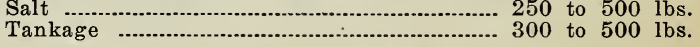

\section{Maturity Table.}

Beans, table use Beets, table use

Cabbages, early, for cutting

Cabbages, late, for cutting.

Carrots, table use

Celery, table use.

Sweet Corn, table use

Cucumbers, table use.

Lettuce, table use

Melons, table use.

Onions, for storage.

Peas, table use..

Radishes, table use

Tomato, table use.....
40 to 50 days 50 to 70 days 70 to 80 days 00 to 120 days 60 to 70 days 120 to 140 , days 65 to 80 days 45 to 60 days 40 to 50 days 65 to 90 days 80 to 120 days 50 to 70 days 25 to 45 days 90 to 100 days 65 to 90 days 
J. H. MUMM, Pres. and Mgr.

YARDS

Corner Washington and Nora

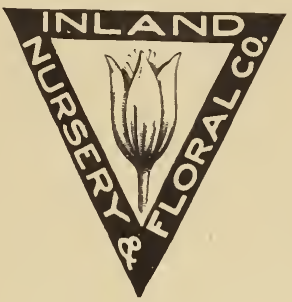

WHOLESALE AND RETAIL

SPOKANE, WASHINGTON

SUCCESSOR TO MOSCOW NURSERY

The Largest and Best Selected Assortment of Shade, Fruit and Ornamental Trees in Washington

Roses, Shrubs,

Vines of all

Kinds

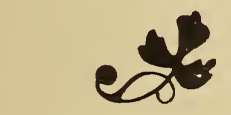

Fine Lot of Nut

Trees

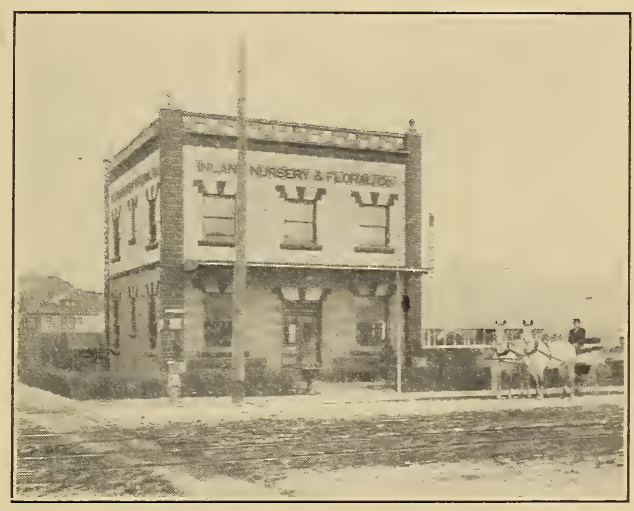

All Kinds Small Fruit and Berries

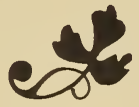

Orders Attended to promptly and carefully

\section{Come and Select Your Own Stock}

The Largest Concrete Green Houses West of the Rocky Mountains. All kinds of Cut Flowers, Palms, Ferns, and Fancy Potted Plants. Orders by Mail Promptly Attended to.

All Our Nursery Stock True to Name 


\title{
Everything for the Farm and Garden
}

\section{Church's Seed Store}

\author{
915 FIRST AVENUE $=$ \\ SPOKANE, = WASHINGTON
}

